APPENDIX .

\title{
INQUISITION IN LUNACY.
}

$\Delta$ Commission de lunatico inquirendo was opened on Friday, Ang. 12, at the Castle of Exeter, at ten o'clook a.m., before Samuel Warren, Keg., Q.C., and a Jury. The person whose sanity was questioned was Miss Phoobe EFings, a lady of 80 years of age, and the petitioner for the enquiry was the nearest relative, 80 years of age, and the petitioner for the enquiry. Was the nearest relative, Dr. Greenup, of Warrington, in Lancashire. Mr. M. Smith, Q.C., and Mr. Q.C., Mr. Coleridge, and Mr. Kingdon (instructed by Mr. Gray), attended in opposition to the petition. The learned Commissioner was attended by Mr. Stewart, a gentleman attached in a responsibile capacity to the Master? Offlo. The jury was composed of gentlemen of high standing in the county, the foreman being G. W. Soltau, Esq. The court throughout the enquiry wae crowded.

The learned Commissioner, in opening the enquiry, said that they had assembled under the authority of the Great Seal, as they had just heard from the officer of the court, to enter upon a question of great delicacy and importance the sanity or insanity of the lady whose name had been just mentioned. He had frequently had to sustain the very painful and anxious responaibility of pronouncing the decision of that question himself, without the intervention of a jury, and heartily rejoicsd that, in the present instance, that responsible duty dy. volved on so large and influential a body of gentlemen, taken from the body of this great county, as he now saw impannelled before him. He was also glad to have the great county, as he now saw impannelled before him. He was also glad to have the
valuable asistance of so many of his learned friends at the bar, whom he rejoiced valuable aesistance of so many of his learned friends at the bar, whom he rejoiced
to meet on this occasion, "I nust remind you," said the learned Comminainner, "that the exact and the only question which you have to try is, the present sanity or insanity of Miss Phœebe Ewings. To enable you to determine the question, a great body of conflicting evidence, I have reason to believe, will be brought before you; [at a subsequent stage of the proceedings the learned Commissioner stated that he had signed nearly 70 summonses to witpesses,] and among other witnesses are medical gentlemen, some of them of great eminenoe. among other witnesees are medical gentlemen, some of them of great eminenoe. invaded, or surrendering your rights to any witness whateoever, however justly eminent. You will yourselves judge of their premises, and the inferences which they deduce from those premises their testimony as men of great experience and skill is very valuable, but it is you and you alone who must their-and indeed of all other-evidence. As the law of England premises innocence till guilt has been proved, so it presumes sanity till insanity has been incos entablished. Finally, gentlemen, it is by this lady's own aot that you are summoned together to-day - in the exercise of that important right which the law gives her. She thereby 8ays, in effect, 'You allege me to be insane : but I will have that all-important question submitted to, and deternined upon, by a jury of my country.' That is the simple question before you, and the learned counsel for the petition will now proceed to open the matter to you."

Mr. Smith, Q.C., then stated the case. He said Miss Phoebe Ewings, the lady who was the subject of the enquiry, was 80 years of age. She was born in Devonshire, her grandfather having been rector of Feniton, and her father a captain of a ressel ; but her mother was a native of Ianoaghire. In the your 1800 , her father died, and her mother was left with four children $\rightarrow$ son, who was an idiot, and died in the same year; and throe daughters, of whom Mise 
Phobbe Erings was the only survivor. In the same year her mother removed to Warrington, in Ianceshire, and Miss Ewings lived there till after the desth of her mother and her two sisters, when she came down to Freter. In 1853, the sister Flizabeth died, and that circumstance prejed much upon Miss Phobe's mind. She was obeerved at that period to be constantly mouning, and she mind we required that her sister's grave should be watched for a considerable periodconse which a sane person would not have adopted. From that time her mind, which was naturally feeble, became still more enfeebled. A gentleman mind, which was naturally feeble, became still more enfeebled. A gentleman, who was related to Miss Ewings, called upon her after her sister's death, but her manner towards him was entirely changed since he last saw her, and she bohaved with great rudeness to him. In the early part of October last she was attacked with paralysis, and was in a great measure deprived of speech. She recovered physically to a considerable extent; but her mind was entirely broken recovered physically to a considerable extent; but her mind was entirely broken down. Indeed, there could be no doubt that disease of the brain had then
supervened, for about that period she had an attack of insanity. She fancied that the persons about her were going to murder her, and she rushed out into the street at midnight. There could be no doubt that at that time she was insane. Mr. Beamont, solicitor, of Warrington, then managed her affairs, and it was thought desirable that medical gentlemen should see her. An investigation took place, and she was placed in a lunatic asylum. Dr. Kendrick and Mr. Sharp, the medical gentlomen who gave the necessary certificates, stated that she was incoherent in her disoourse, and violent to her attendants, imagining that they attempted to strangle her. Down to the present time there was the same incoherence, and she still laboured under the same dolusion. Upon the certificates of Dr. Kendrick and Mr. Sharp, she was placed in the Haydock Iunatic Asylum on the 30th of December last, her property being taken care of by $\mathbf{M r}$. Beamont. She then fancied that the persons at tho asylum were endeavonring to make her a Roman Catholic. After being there a short time her relatives thought an asylum was soarcely a fitting place for a person of her means. The Rev. H. T. Hlacombe, the rector of Clyst, in this county, and a first cousin to Miss. Frings thinking himself the next of kin, visited her at Warrington and removed her from the asylum, with the view of placing her with some of her friends. Steps were then taken by Mr. Beamont, who now opposed the present petition, to apply for a Commission of Lunacy, at the instande of $\mathbf{M r}$. Fllacombe. Pending these proceedings, she was taken from the asylum, and bronght to Exeter. When she got to the railway station she exhibited great violence, showing that she was still in a state of insanity. Sho was placed in a first class carriage, but she thought it was a second, and alleged that grest indignity had beeen shown her. On arriving at Exeter she was taken to the lodgings of Miss Cousens, with whom sho had formerly livel. Mr. Ellacombe thought it would be desirable that a medical man should seo her; and he called in Dr. Shapter. At that time her manner to Mr. Ellacombe was very kind; but it was suddenly changed, and she became entirely subject to the influence of $D r$. Shaptar. Mr. Fllacombe called a short time afterwards, but she refused to 800 him. Sudden changes of this kind were generally a symptom of unsoundness of mind. Mr. Ellacombe was requested by Dr. Shapter not to visit her; but Dr. Shapter assured him that there should be no dealing with her property, with which he should not be made acquainted. He also added that Mliss Ewings had placed herself under his care and protection. About this time it was discovered that Mr. Fllacombo was not the next of kin, but that the gentleman who filled that position in the family was Dr. Greenup, who resided in Lancashire. That gontleman came to Exeter in April : and Dr. Shapter at first refused him permision to see Miss Ewings. He did, however, subsequently have a short interview with her, and his opinion was that sho was not of sound mind, and was not able to teke care of herself. On his return to Lancashire, Dr. Greenup wrote to Dr. Shapter asking permission for Dr. Fox, a well-known suthority, to vivit Miss Ewings. Dr. Shapter made no reply; but a letter was receired from Mr. Beamont, who was then acting with'Dr. Shapter and against the relatives, giving a flat denial. Under these circumstances, believing Miss Ewings to be mad, Dr. Greenup petitioned the Lord Chancellor for a commission to enquire into her state of mind. The case came before the Iords Justices on the 3rd of June. The application was opposed by affidavits from Dr. Shapter, and from 
somo medical gentlemen whom he had called in; but the Lords Justices were not satisfied, and they directed Dr. Bucknill of this county, to make an im. partial report. That gentleman in his conversations with Miss Ewings, discovered that ahe had made a will, leaving the whole of her property, excopt a few legacies, to Dr. Shapter. She was utterly unable to give any acoount of her property, but she produced a paper, written by Dr. Shapter, on which there was property, but she produced a paper, written by Dr. Shapter, on which there was statement of the sources of her income, the property being set down at
$\mathbf{1 3 , 7 0 0}$. She herself did not know how much it was, or how it was invested. Another extraordinary fact appeared, namely, that Dr. Shapter had been appointed by her the guardian of her property and her person. It was certainly : strange thing that a ward should make a will in favour of her guardian; and the lar observed verr great jealousy in such cases. But why pas Dr. Shapter the lar obrat was happy to come to an explanation given by Dr. Shapter, namely, that he did not intend to derive any personal benefit from the affair. But, if a person of sound mind chose to give another his property, why should not that other person acoept it? Upon Dr. Shapter's affidavit going before the Lords Justices, they at once granted the Commission. In a letter to Mr. Beamont, Miss E wings's solicitor, Dr. Shapter said, "I have consented to undertake this charge, (the guardianship) and will, therefore, be obliged by your coming here and taking her instructions and doing what is requisite." On the 12th of March, a month after her arrival in Exeter, Dr. Shapter wrote :- "Miss Ewings has never said anything to me about making a testamentary disposal of her property, but I beg most explicitly to state that $I$ shall not in any way suggest or interfere with her disposition of her property ; save that, were she to propose to bequeath any property to me, placed in relation to her as I now am, I should use my infuence to counteract such an act, and should undoubtedly repudiate every one who had the opportunity of assisting in the realisation of his own everf one The cocont which Dr. Shapter gave of the instructions for the prophoog. The account which Dr. Shapter gave of the instructions for the will was this :- In the 1 irth of May sie desired me to take her instructions however, urged me to comply with her request, and $I$ at last consented to take her instructions. She then declared certain legacies, amounting altogether to $\$ 1,000$, and desired me to be residuary legatee. I objected, but she positively insisted, and expressed the greatest desire to constitute me residuary legatoe, 80 as to dispose of all her property, preferring me to anyone else. To relieve her mind, but still adhering to my determination previously made known, not her mind, bnt still adhering to my determination previously made known, not to avail myself of any benefit, I added my name as residuary legatee, and ahe then signed the instructions." Was that the mode in which a sane person was
usually treated? Would he not have said, "I am much obliged to you, but I really oannot take this benefit; and if you make such a will it will not be acted upon'" A solicitor was called in afterwards, and a copy of the instructions given him. This was just prior to the hearing before the Lords Justices; and the will Tas made behind the backs of the relatives. Giving Dr. Shapter the fnlleot madit for honourablo intentions, no man conld any that his intontions conld bo crodit for hon aurablo (n) me absolute, and it would then be beyond his power to control it. The repudiation of the $\$ 12,700$ in the letter to $\mathbf{M r}$. Beamont was no legal obligation upon Dr. Shapter. There was another faot which seemed to show that Dr. Shapter did not treat Miss Ewings as a perton of sound mind. In his affdavit he declared that he had never reoeivod any foes from her, and that he had not cashed the draft for $£ 30$ which she had given him in return for small sums he had advanced to her, nor would he allow his daughter to accept a present of a work-box from Miss Ewings ; and yet he took the will in his own favour. It was difficult to understand such conduct except the wil in his own on this theory-that Dr. Shapter was under some delusion that she was of
cound mind, while in his own sane senses he believed she was not. He must have had two minds on the subjeot. He had the delusion that Miss Ewings was ane; but as an honest man he thought she was not; and as an honest man he would not take the benefit of anything she gave him. The learned counsel then gave a summary of the evidence which he intended to produce. In conoluwion he said that six months ago Miss Ewings was in an asylum raving mad, and it was plain that ahe was now in a state in which any man of intelligence, who 
IV

was friendly to her, could do as he pleased with her. Dr. Shapter might exercies his onntrol for the best, but supposing she took a sudden dislike to that gentleman and became rubject to the control of another person, there was no guarantee that ahe would be properly treated. The object of the present enquiry was to place her, supposing she was of unsound mind, under the protection of the Conrt of Chencery wich would sppoint responsible and impartial persons to care for her. He (the learned connsel) believed the jury would arrive at the conclusion that owing to her unsoundness of mind she was nnable to manage her property.

The following witnesses were then exanined :-

Dr. James Kenrick : I am a doctor of medicine residing at Warrington. I have known Miss Ewings for many years. I never attended her professionally until Ootober, 1858. For the past few years there appeared a listlessnees in her manner, she walked in the streets as if she was walking neither for pleasure nor manner, she walked in the house in October last I was told that ar pleagure nor paralytic attack. Upon visiting her I found the usual symptoms. I thow t from paralytic attack. Upon visiting her I found the usual symptoms. I thount from one circumstance that she was incoherent. Her speech was imperfect, and In pulse low. I called again and found the pulse better. In the December followin I examined the state of her mind. I found Mr. Wood and Mrs. Monld with her. I had a converation with her, and am of opinion that she was then decidedly insane. I gave a certificate acoordingly. I may say that I found her in an excited state. She said that she should like to be taken away from the in an oxcitod house. I said, where would you like to go, and she replied "I do not know." Upon mentioning Torquay she either said that she did not care about going there, or that there was no one there that cared about her. She said, "Would those creatures follow us there?" This was said in referenos to statement that during the night some demons had attempted to strangle her and rob her. I believe mention was made of the demons being outside the door at that time. I said to her "Certainly they will not follow you." She talked of liking to go to a Mr. Greenall, who is a magistrate, and also about a $\mathbf{M r}$. Iowe, who had been dead twelve months. She said she should like to go with him to Mr. Greenall's Mr. Wood, the clergyan of the parish, was present but Miss Ewings treated him as Mr. Lowe, who was the former clergyman. I bat no doubt of her state of mind when I signed the certificate.

Cross-examined : Mr. Sharp is the regular medical attendant of Miss Ewings. The attack of paralysis might produce a confusion of words, at least to a certain extent; but if often repeated I should look upon it as a confusion of ideas and not of words. When she was taken to the asylum she thought she was going to Mr. Greenall's.

Mr. Smith said he understood his iearned friends admitted that she was of ansound mind.

Mr. Collier : Not in October. I admit that she was in December.

Ann Worrall : I formerly lived as servant to Miss Phobe Ewings. I am now living with $\mathbf{M r}$. Hardy, in Cheshire. I lived with this lady about three jears ago. I stayed 15 months, then went away, and returned in Jannary of last year. I recollect Miss Ewings having a paralytic attack in Ootober. It was very sudden. I went for a doctcr. I was not the only person in the house. I went for Dr. Kenrick, Mr. Sharpe not boing at home. I think that paralytic attalk afected wards as before. I observed that she called Mr. Ashton Miss Ashton's wards as before. I observed that she called Mr. Ashton Miss Ashton's
sister. This lady was afterwards with her. She frequently called persons by wrong naines.

By the Commissioner: This was after the attack of paralysis.

Re-examined by Mr. Sinith : I don't remember her calling persons by their wrong names before she had the attack. I recollect her being taken to the Haydock Lunatic Asylum.

The Commissioner : I think it is admitted that at this time the unsoundness was apparent.

Mr. Smith : This evidence is merely to show the character of the unsoundness.

Examination continued : One night Miss Ewings followed me upstairs, and then ran out into the street. I followed her in order to take care of her. This wa botwoen nine and ton o'olook in the orening, and sho was dreatedi 
We got her back, but she ran out again. She said she thought there was some one in the house. I did not hear her say what she thought the person would

do to her. There was no one in the house at the time but myself.

B the Commissioner : She had only one servant.

Eramination continued: The second time she went out she remained until Mr. Bharpe came. When she was brought back she would not go to bed

By Mr. Collier : There was no "follower" of mine in the house. (A laugh.) Mary Lawton : I am a servant in Mrs. Lowe's employ at Warrington. I knew Miss Ewings for the last nine or ten years. She used to come almost every day to Mrs. Lowe's. I always thought her a "curious" sort of person. By the Commissioner : I thought so for nine or ten years. She used to dress very shabbily, and her house was very meanly furnished.

Framination continued : I remember her sister's death. After that she nsed to be very sorrowful. She used to sigh and moan. Her sister died in 1863 and that I think affected her a good deal. I heard her say that she would have her sister's grave watched. I remember her having a paralytio stroke. I stayed in the house two nights by Mrs. Lowe's desire, there being only one servant kept. Miss Ewings did not know that I was there. The second night she oalled out "Fire!" and said the house was on fire. The honse was not on fire nor was there any light or fire in the house at the time. She shouted out- "Who is there? Some one is there"-just before she was taken ill I saw her and she then said I was Mrs. Lowe's sister. She told me twice that she was afraid of being murdered. One time she called me "Mrs. Wood" She told me that she was afraid the window would be blown out. Ehe said there wros a dreadful storm, instead of which the night was beantifully fine. Just after that she went to the asylum. I went to Exeter with her by the permission of Mrs. Lowe. She went in Mr. Nicholson's carriage, and on the way to the railway station, she "rambled" all the way. I cannot ray whether she was alarmed or was in a merry humour. I did not understand what she said.

By the Commissioner : Mr. Nicholson and Mr. Fllacombe were with us. Examination continued : When she got to the railway station she screamed out "murder," and said they were going to make a Boman Catholio of her. She screamed "murder" several times, and called out for the police. Her manner was violent and she appeared terrified. After some troublo she was got into the railway carriage. Mr. Nicholson went with us as far as Birmingham. At Birmingham, when Mr. Nicholson got out of the carriage, she imagined that it was Mr. Beamont, and called out "Mr. Beamont, Mr. Beamont."

By the Commissioner : Mr. Beamont was her lawyer, and was not near at the time.

Examination continued : She called out and wanted to know if they could not "start," saying that she had been travelling all the winter. "Can't you start us," she said, "wo are almost frozen." All the way to Exeter her manner was "rambling." I saw her taken to Migs Cousens, in this city.

Cross-examined by Mr. Collier : It was after the death of her sister that I observed the "sighing and moaning" I did not see her while she was in the asylum. At the Warrington station I saw Mrs. Barnsley, but I cannot say whether ske keeps a private Lunatic Asylum.

By the Commissioner: I cannot tell whether it was after or before she saw Mrs. Barnsley that she refused to go.

Cross-eramination continued: I do not think that the two porters who were called to assist in placing her in the carriage placed her in feet foremost. Will swear they did not put her in by force. One porter rode in the carriage with her. Mr. Nicholson and Mr. Ellacombe gave orders that this porter whould ride in the carriage.

By Mr. Collier: I did not hear Miss Ewings say to Mrs. Lowo- "You, a clergsman's widow, and order me to be forced into a carriage!" I did not take sufficient notice to see whether she was tired or not. I did not ask her. Mr. Coleridge : What were you there for?

Witness : I was sent for company. She had refreshments at Birmingham ; sho came from Birminghsm to Ereter without any. I had refreahments 
myself at Birmingham, but not anywhere else. When Miss Ewings was at Miss Cousens's she seemed very happy ; I have not seen her since.

The Rev. Ralph Allen Mould: I am the incumbent of Holy Trinity, at Whe Rev. Ralph Allen Mould: I am the incumbent of Holy Trinity, at Her sister died in 1853 . After that I observed that she walked in the streets "sighing and moaning." I heard that she had an attack of paralysis. When she began to go about again, I observed that she seemed in low spirits; and she used to call my mother my sister; and her general conversation was about her being " miserable."

By the Court: She complained of " those creatures." I said "Why do you complain so "' and she replied "Oh dear, oh dear, those creatures." I cannot say that I formed an opinion of the state of her mind. The day before she was removed to the asylum her servant ran into my house to summon me. I afterwards heard her screaming; she did not articulate any particular sound. I went into the house about ten o'clock in the forenoon. When I went in I found the nurse who had sat up with her during the night apparently struggling with her to keep her away from the window. When I went in the servant released her. Miss Ewings caught hold of the collar of my coat, and asked me to protect her. She said, "They are trying to strangle me and murder me" "She repeated those words many times over. I tried to pacify mer, and convince her that she was wrong; but I did not succeed. I tried to induce her to sit down in an easy chair near the window. She walked across the room still holding my collar. She then beat the window with her fists as if to attract the attention of any one who might pass. I took hald of one of her hands to prevent her breaking the windows, and got one of the servants to draw down the blind until the arrival of Mr. Beamont, who had been sent for. Mr. Jeamont, Mr. Wood, Mr. Sharpe, and Mr. Kenrick were sent for. Wo held a consultation, and it was then that we thought she had better go to an asylum. I and Mr. Wood signed the certificate.

Cross-examined by Mr. Collier : I have every reason to believe that she was attached to her sister. I think that when a person continues in the state of mind in which Miss Ewings was for so many years-walking backwards and forwards in the street, sighing, \&c., although it may not be a sign of insanity,

it is a sign of simplicity and disorder.

Mr. James Nicholson: I am an attorney and solicitor practising at Warrington, and living there. I have known Miss Ewings for many years. I remember her walking in the streets. She had great difficulty in compreI remember her walking in the streets. She had great difficulty in compro-

By the Commissioner : I would not say positively whether I noticed it before her sister's death, but it might have existed.

Examination continued : I understood that there was an objection by some of her friends to put her in an asylum. In consequence of what was said I put myself in communication with Mr. Beamont. I went to the Haydook Asylum in company with Mr. Wood. I had expressed my dislike to her going to an asylum, and was aware that she had means to support her out of one. When we went to the asylum on the 29th of January, I and Mr. Wood were introduced into the sitting-room. There was an attendant. Dinner was on the table. As soon as she saw us she rose up in a state of the greatest excitement, and seized hold of my hand. She seized hold of me with one hand, and Mr. Wood with the other.

The Commissioner : Pleased or excited?

Witness: In a sort of "phrenzy, or of uncontrollable passion." We reguested her to sit down on the sofa. She did so, and then addressed me "Oh! Richard Richard." My name is James She repeated the expressions many times. She then said "Richard Greenall." There was a Mr. Greenall many times. She then said "Richard Greenall." There was a Mr. Greenall
living in the neighbourhood of Warrington. She said "Don't leave me, don't leave me, they will murder me." She said this in a very excited manner, and then added "they will murder me to night." Both I and Mr. Wood did our utmost to pacify her. She then said, "They are Roman Catholics here, they are Roman Catholics here." Her conversation did not seem to have any connection. I made use of some such expression as "nonsense;" but she said "They are, they have a priest, and they want me to go to their prayers."

By the Commissioner : Slie is a Protestant.

Examination continued : Her conversation was decidedly incoherent. 1 
have given a fair sample of her manner. I put myself in communication with Mr. Beamont both previously and subsequently. In February I undertook on my own responsibility to take care of Miss Ewings and place her in a privato place. In February I received a letter from Mr. Beamont, informing me that might take the responsibility upon myself. I assented. That wa on the 11th of February, 1859. Several lady friends requested me to take her out of the asylum. The next day after I had the consent, Mr. Fllacombe called upon me. He was then a perfect stranger to me. Mr. Beamont told me that he was a relative, and rector of Clyst St. George, near Exeter. The name of Ellecombe was familiar to me. I had had conversations years before with Miss Evings about her family podigree. I then understood that Mr. Ellacombe was ready to receive Miss Ewings into his charge when I said "Of course now a relative has appeared my office is at an end," and I retired from any further action in the matter. At his request I accompanied him to the Haydock Asylum, which is a private one. When we saw Miss Ewings, her conversation and manners were pretty much the same as before, but we were only with her a short time, gay a prearter of an hour. We communicated to her that we were going to taleo quarter of an hour. We communicated to her that we were going to take
her away. She was then very much excited, and seemed gratified beyond measure, and went down on her knees, and offered up a prayer for her deliverance. She asked for her shawl and bonnet, and put them on. Mr. Ellacombe conversed with her more than I did, calling to her mind family matters.

By the Commissioner : She went with us eagerly. She kissed every body around her before she went. Immediately after we had left the asylum whe became very excited indeed, and seized hold of me. This was without apparent became very excited indeed, and seized hold of me. "' This was without apparent cause. She addressed me "as "Oh, Joe! Oh, Joe!" She looked wildly out of Joe !" before. She said "You are deceiving me, you are deceiving me" at the top of her voice. I endeavoured to persuade her that we were not deceiving her. When we passed by churches, \&c., I pointed them out, but she denied that there were any at all. At Newton I pointed out a church but she said "It is nothing of the sort, it is no church." We took her to Mrs. Lowe's, she begging that we would not take her to her own house. She did not give an reason for it. She stayed there till the morning of the 15th. I then accompanied her to the itation at her own request. I said, "I will go with you, Miss $\mathrm{Ewings}$, if it station at her, own request. I said, "I will go with you, Miss Ewings, if it was guing to her "dear Devonshire," having heard her express herself in those terms of that county. Mrs. Lowe's servant also accompanied her. When te were leaving Mrs. Lowe's house, I said "We must not lose time ;" and she replied, "Oh, I must have my time." When we got to the station her manner was perfectly quiet, and she did not apparently object to leave. She manner was perfectly "quiet, and she did not apparently object to leave. She "Murder, murder; police, police; they are going to make a Roman Catholic of me." This was just as the train came up. I do not think that it was upon seeing Mrs. Barnsley. Her passion for the time was uncontrollable, and she continued to cry "Murder and police." Mrs. Lowe endeavoured to pacify her, reminding her that she was going into Devonshire. It was when on the point of starting that tlie porter was requested to help. She was not taken up and put in feet foremost. There was no violence more than "pressure." In consequence of the outbreak, Mr. Ellacombe got one of the porters to come into quence of the outbreak, Mr. Ellacombe got one of the porters to come into tho oarriage. I rather think I suggested it. Her manner was very much worse than it was before. I went with her as far as Birmingham, but during
the journey she spoke very little. We tried to draw her into conversation, but did not sucoeed. At Birningham she seemed perfectly content and tranquil. She had refreshments there with the servant, Mr. Ellacombe, and myeelf. She did not appear to be alarmed at the appearance of Mr. Ellacombe.

Cross-examined by Mr. Collier: I am attorney for the petitioner. I did not at any time maintain that she was not of unsound mind. I did not my her case was that she might have been provided for otherwise than by going to an asylum, that she might have been cared for in her own house. I did not threaten to apply for a habeas corpus on the ground that she was not mad. I cartainly threatened to apply for her discharge from the Lunatio Aoylum.

The Commissioner: Did you threaten to apply for a habeas corpous? You

lnow very well if you did; you are an attorney. Witness : $\mathbf{M Y}$ letter will 
asy. I certainly threatened to make an application on her behalf. [The letter was then read. It stated that in the writer's opinion "Miss Ewings was miproperly confined in the Innatic Asylum."]

The Commissioner : Did you write this? Witness: Yes.

The letter went on to say unless she is at once released from the asylum, I cannot refuse to act in accordance with their (her friend's) instructions, and apply for a habeas corpus, or in such way as counsel may adviso."

The Commissioner : Did you write that? Witness : Yes.

The Commissioner: Did you not know, as an attorney, that you had no right to a habeas corpus, except upon the ground that she was not mad? Witness : I cannot say that I 80 minutely weighed the letter.

Mr. Collier : Did you not know perfectly well that the only ground for a habeas corpus would be that she was illegally detained, not being uad ? Witness : I considered that my application would be that she would be delivered up to her relatives for them to take charge of her.

In reply to the Commissioner the witness said: I cannot say that I considered it in respect to that point of law.

The Commissioner: On what ground, if not on that ground, could you make your application ?- Witness: That she had been hurried away from her house, under the pretence that she was going to see some friends.

Mir. Collier : Do you mean to say that you threatened to apply for a habeas corpus becanse she had been taken to the asylum under the pretence that she was going to a friend's? Pray be careful, I am sorry to say so to you. Was going to a friend's? Pray be care

The Commissioner : What was the rest ?-Witness : I considered that Miss Ewings could just as well be cared for and attended to out of the asylum and under proper treatinent as in the asylum.

The whole of the letter was then read. In addition to the above passages it stated that Miss Ewings' friends were desirous that she should not be kept in the asylum.

The Commissioner : A habeas corpus is a matter of right.-Witness : Yes.

The Commissioner: Then could the application do anything else than state that she was not inad?-Witness : No; but the letter was written in the hurry of the moment and without due consideration.

Mr. Collier : Did you not tell Mr. Beamont that you thought she was not mad ?-Witness: I will swear that I did not say so. I objected to the way in which she was hurried away from her house and confined.

Examination continued by Mr. Collier : I saw her on the 29th of January, more than ten days before I wrote this letter. She was extremely anxious to get away from the asylum. She said "They will murder me," and expressed great dislike to be there. When she was taken away I accompanied her in a great dislike to be there. When she was taken away I accompanied her in occur to me that she might think that having been "tricked" once she was occur to me that she might think that having been "tricked" once she was going to be tricked again. She did not say that she mistrusted where we were
going to take her. I told her where we were going, but she denied the truth of it. When at the railway station she called out before Mrs. Barnsley came up to her. I differ from the other witnesses on that point. I was ntterly unable to acoount for her orying out. She had been tricked once, but I will not say whether it was through this that she cried out. The porters led Miss liwings to the carriage. She was nnwilling and resisted, but I cannot say that she made "active" resistance. The porters said, "Now, lady, the train is going made "active" resistance. The porters said, "Now, lady, the train is going wards. $I$ and Mr. Ellacombe were standing by when the porters put her in There is a Roman Catholic chapel at Ashton, about a mile from the Haydock Asylum. I cannot say whether there were any Roman Catholic patients in th aylum. It was my intention if she came out of the asylum that she should be taken care of, either by myself or other friends. I have known Miss Ewings for 30 years, and her manner was always very peculiar. Her conversation was strange, and she was essentially dull in comprehending. For the last seven or eight years she had a difficulty in remembering names and oircumstances. I concidered that it formed a feature of her conduct, and it must have struck every body. I do not know that it occurred to me that this peculiarity was any sign of her madness.

Flisabeth Bennett : I was attendant at Haydock Lodge Asylum, but I am 
not 80 now. While I was there I attended on Miss Ewings, who always seemed in a very excited state. She said, "I am sent here, because my cervant ill-treated me." At another time she said, "There are some persons behind the door coming in to hang me with ropes, or kill me." This she repeated whenever she 7 as left alone. When she came to the asylum she had some moner concealed in her atays. The state of her mind was bad. I do not think she was capable of talking care of herself.

Cross-examined by Mr. Colerilge: When I was putting on her dress she said, "Here is sumething to bay me a dress." What she said led me to look for the notes.

By the Commissioner : The notes were stitched in a piece of allico, both sides of the notes were covered.

Mr. Daniel Rossiter : I am resident surgeon, at Haydock Lodgo Asylum, and have been connected with other asylums before. I was at Hajdock when Miss Evrings came there, and I visited her daily. Her memory was very defeotive, she laboured under several delusions, one of which was that she was going to be murdered, and after she had been there a month she believed that we wanted to uake her a Roinan Catholic. This delusion continued the whole time she was there. There is a chapel in the asylum, the service being conduoted by a clergyman. There are no Rounan Catholic ladies in the asylum, and I can say that no attempts at conversion were made. When she left her health was better, and there was a slight improvement on the mind, but I consider that when she was in the asylun, and when she left, she was insane.

when she was in the asylum, and when she left, she was insane.
Cross-examined by Mr. Collier: She had apartment to herrelf. She always had an attendant, Elizabeth Bennett, who did not attend on any one else. When there was any amusement going on she came down into the ladies' room. Soune of the ladies could visit her.

By the Commissioner : I cannut undertake to say that no Roman Catholio patient had communication with her. I cannot say to two or three dosen how many Roman Catholic patients there were, but to the best of my belief there was no private Roman Catholic patient there. The others were paupers. Both classes were provided for in the asylum.

The Commissioner : Do you call it a first-class establishment?

Witness : Yes, we take private patients. At the time Miss Ewings came, there was about 140 paupers and 40 or 50 private patients. 60 of theee might have been Roman Catholics. The priest came about four times. There in only one priest that ever visits the lodge; there may be more in the neighbourhood. The first time I was told of his coming was in March. I found that the priest occasionally came there, and I gave directions that I ahould be told when he came.

Ro-examined by Mr. Karslake : I have no reason to doubt that my intructions were obeyed.

By the Commissioner : Miss Ewings went to the chapel and conduoted herself well. I will not swear that there was no Roman Catholic lady there, but I believe they were all Protestants.

By Mr. Karslake: There is no communication between the paupers and private patients.

By the Conmissioner : I never heard of a proselyte. I have heard patient: complain of the priest not visiting them.

'I'he Rev. H. T. Ellacombe, rector of Clyst St. George: I am a relative of Miss Ewings; I was supposed to be the next of kin; I am a third cousin once removed. I had a correspondence between 20 and 30 years ago with the Misees Ewings about our family pedigree or relationship. The letter might have been sent to the sister who is dead. I do not think that I had ever seen Miss Ewings till I went to Warrington. I received a letter from a lady, a stranger, in consequence of which I wrote to Mr. Besmont sayiny that I believed I ras consequence of which I wrote to $M r$. Beamont, saying that I believed I was
related. I went to Warrington on the 11th of February. I was informed related. I went to Warrington on the lith of February. I was informed gentlemen who had signed the certificate. I afterwards made an arrangement with Mrs. Lowe that she would receive her until she could be placed in comfortable lodgings. I went to the asylum, and I was introduced to Mins Eringer. and she said "When " She was told "Now." When she was antinfied of our 
Intentions she fell on her knees and appeared thankful. She took $m y$ arm and rent down stairs, where I handed her into the carriage. Before she left she kissed all the attendants. On our way to Warrington she "rambled" in her conversation. [The witness then confirmed much of the previous evidence as to the absence of mind manifested by Miss Ewings as to certain things and places on the route.] I made arrangements for Miss Ewings to come down to Devonshire with me. I took her to Miss Cousens, and reported come down to Devonshire with me. I toak her to Miss Cousens, and reported
her to Dr. Shapter. She arrived here on the 15th of February. When I left her at Miss Cousens I said she would remain there only a short time. Dr. Shaptor gave orders that no one was to see her, and I did not see her when called the next day. I saw her on the following Friday, and she asked what I had been about, and I replied, to try and get a comfortable place for her; but

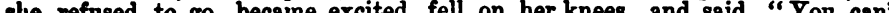
take me away, I am very comfortable." I said I ain not going to take you away immediately, but you inust go. I have since met her twice accidentally. I wo prohibited from visiting her, and I consequently made no endeavour to do so.

By the Commissioner : I refrained from visiting her becanse I nnderstood that it was the wish of Dr. Shapter, and also that she had taken a great dislike to me. I afterwards understood that I was not the next of kin. Mliss Ewings was born in 1780 .

The Commisaioner : How do you know it? Witness : I have an affidavit made by her mother.

Cross-examined by Mr. Collier : Miss Ewings was gled to come to Ereter, but I did not hear her say anything after I left her in the custody of Miss Cousens. I cannot say whether Miss Ewings was very glad to see a servant callod Mary. I will not undertake to say that she recognised that servant. I believed she was comfortablo at Miss Cousens. When I went to her the next morning to tell her that I had a comfortable house for her, she did not seem inalined to go. The words J used might have been, "That she must go," but she was excoedingly annoyed at it. I did not attempt to persuade her, though I gave ber to understand that she must go.

Be the Commissioner: I did not think from her manner to me that she had taken a dislike to me. She has the demeanour of a lady of education.

By Mr. Collier : I cannot say, without looking at iny notes, when I learnt that I was not the next of kin. I do not know when I heard that Dr. Greenup was the next of kin. I have made no arrangement with anyone respecting this matter.

By Mr. Smith : At Warrington she said she was very glad to see me, and that I should have all the money she had. From my own observation of Miss Ewing ahe appeared to be a person of weak intellect and not capable of managing her own afiairs. I have uade a note to that effect.

By Mr. Collier : At the interview on Friday after she came down, I did not think she was sane.

Mr. Collier: Was there anything at that interview to show that she was of uncound mind?

Witness, after a long pause : If I had not seen her before I should not have said anything about it.

The Commissioner repeated the question and the witness replied : Certainly not, nothing occurred to lead mo to think she was of unsound mind.

By Mr. Collier: She knew the persons where she was staying, and was aware I wished to remove her.

By Mr. Smith: My opinion from the whole of the interview was that she was of unsound mind. I have done duty in a Lunatic Asylum, and have had a gentleman lunatio under my own care.

Dr. Frederick Greenup : I am the petitioner in this case. Some years since, abont 14 I called upon the two sisters. The conversation which ensued about our relationship lasted twenty minutes. At that time Miss Ewings appreciated our relationship lasted twenty ininutes. At that time Miss Ewings appreciated she was in Exeter. It was my intention to call upon her. Before going to see her I called upon Dr. Shapter understanding that he was her modical attendant, I told him I wished to see her.

The Commissioner here interfered by saying that he was not here to enquire into the conduct of Dr. Shapter, but only to ascertain the state of Mlise Ewings' mind: 
Yr. Collier: I ahall anll Dr. Shaptar.

The Commiscioner: I do not either want to oriminate or to ercenerate Dr. Shapter.

Framination continued by Mr. Karslake : I went to 200 her, I cent in my oard, but she eaid she did not know any one of the name. I said I had come from the neighbourhood of Warrington, and that some of her intimate friends of that place wished to 800 her. I mentioned the name of Mr. Nicholson, when we heaitated and raid, "I dont know the name." She afterwards said to me,

Are jou Mr. Nioholeon ?"

The Commiscionar : Did she put the question?

Witness: Yes, I am quite certain. I then explained who I was and Mise Bwings's attendant in a very kind manner explaingd the matter, but ahe meraly maid, " $\mathrm{Fh}, \mathrm{Eh}$," and made no further reply. Mentioned other perwon's namee and partioularly that of Mr. Blackburn, but she did not know them. Aftar time she said, "I am much obliged to them." T was with her about a quarter of an hour. I considered that her memory had in a great measure left her. I should say that her intellect as far as reganded memory had cone An application that Dr. Fox, of Bristol, should see her was answered by Mr. Beamont.

The correspondence upon this point was put in and read.

Crose-examined by Mr. Collier: Dr. Fox has since seen her. I had seen Miss Ewings once in my life before.

Mr. Collier: Do you generally make such an impreasion npon ladies (Ianghter.)

By Mr. Collier: Miss Exings did not intimate that she thonght I was come for her money. I only came to judge of her mental state. I did not come to Freter- to 800 if I was next of kin but I had that object " nitimately"

Mr. Collier: "Ultimately !" Did not the old lady know what you came for? Witness : No; when $I$ saw her 14 years ago it was at the suggestion of my sister. During the interval I have not sent any message. I have mado enquiries from other persons. I did not come to Exeter nntil I understood that I was next of kin. I have brothers and sisters. I have not made any arrancement that 70 are to share the costs of this action. I am to bear the coet, but if I am nnguccosful I believe my brother will bear mo ont I presume that $m y$ brother will have part of the money, or at leat an much an he law allows.

Christopher Holland : I am a surgeon practising at Norwich, and am a consin of Miss Ewings. In 1827 the two sisters sought mo out at Honiton: I wais then an apprentice. They understood from enquires that I was the sole survivor. They were staying at Sidmouth, and invited me to visit them. Their manner was very kind. In 1831 they again visited Devonshire, when I saw them. I dined with them at the York Hotel, and they were very Find to me. In 1853 I heard of the eldest sister's death. I visited Min Phobe in that year, at Rochdale, and she received me with great rudeness. She knew me perfectly well.

Dr. John Charles Bucknill : I am the superintendent of the Devon County Lunatio Aoylum. I have been so 15 years. During 18 years I have had experience in lunacy. The present number of patients in the asylun in 600 , and it has increased gradually from 400 . If you take the average it would be 450 . I receired a order from the Lords' Justices to visit Miss Bwings, and to report to them upon her mental condition. I visited her npon the 6th, 8th, 10th, 11th, 13th, 15th, 17th, and 21 st of June. The intervie we were generally long. 11th, 13h, I made notes of my visits. The result was that I thought that her powers of I made notes of $\mathrm{my}$ visits. The result was that I thought that her powers of mind were in state of decay, and that she was undoubtedly in an unsound
state of mind, not being able to manage her own property. She was very state of mind, not being able to manage her own property. She was very
tranquil, and seemed glad to seo me; she offered me roses and strawberries, and pressed me to see her again as a friend. In the first interview I elicited very little except defective memory. The memory was particularly defectivo 7 th regand to namesor (1) possessed, 80 much so indeed that person not going below the "surrace," might obcervo no dofoct. On the second interviow, although acis sining was generally tranquil, I found that she had been crying, and ghe said that Dr. 
the matter. She also said trequently, "Won't you protect me, won't you beome my friend. They won't take me away and nee me oruelly on 1 anked her if she was used cruelly in the asylum, and she said, "Oh ! no, I have been then examined her with the view of eliciting a delusion which ahe had in the aoplum as to her attendants wanting to kill her, and sho laughed at tho idea, and denied that she had ever entertained such a thought. She said that sho had heard strange noises in the asylum, but that they had been explained to her. She could not tell how long she had teen at her present lodgings in Exeter. She asid she had been here about six months, and Miss Cousens who wras present remarked-"You mean to say you have left home six months." Miss then said she left home at Christmas. When I explained that I wanted to tno- ho long she had been in the house, she could not then tell, but afterwards she repeated that it was six months, which confirmed my opinion as to the loss of she repeatod that it was six months, which confirmed my opinion as to the loss of memory. She was afterwards spoken to about her property, and the death of drawing of Feniton church, of which she said her father had been rector. I believe now that it was her grandfather who was rector. She added that her mother was wife to Dr. Bertie, oousin to the Earl of Derby. Other part of the conversation confirmed my opinion as to her loss of memory. She proseeded withont any enquiries from me to say that she had no relatives. She said that Mr. Fillacombe was not one, and that she had never seen him in her life before he oame to the anglum. Then she procoeded to say, that she was afraid they Tould take her away, and that she thought they only wanted her money. I aaid "Very likely "" and she said "I will take care that they shall not have any ; it is all provided for." She then stated that she had made a will leaving come legacies, and also some money to the Christian Knowledge Society bri all the rest to Dr. Shapter who had been a very kind friend to her. I aked her this onguiry is being made to prevent your making a will," when she replied "It is andy done" bre in a manner which made me doubt whether the will had actually been made. She avid Dr. Shapter had made all the arrangements, and was to have the management of everything. Before I went to 200 her I asked Dr. Shapter to inform her of my visit and its purport, and I dare any that he had done so.

The Commissioner : What made you doubt it?

Witness : She mentioned it in a hesitating way, as if in fact she was only expresesing an intention. I wrote down my impressions at the close of each interiog I enqnired what her property was and she said "I don't know" interview. I enquired what her property was, and she said "I don"t knnow." and she said "I cannot." "Any money in the banker's hands"" and she replied and she said "I cannot." "Any money in the banker's hands "?" and she replied was "of funds and railway shares." Upon the point of time I auked her the day of the week.

A discussion here took place between the Commissioner and the connsel respecting the report of Dr. Bucknill, which was very volumious. The learned Commisesoner remarked that if he had a full copy before him, he hardly thought it would be necessary to write down Dr. Bucknill's statement as read from notes of which the report was a copy. The original report sent to the Lords Justices was then handed to the Commissioner.

Dr. Bucknill then procoeded to read his report at length. The following were the most striking passages :- "Did she know the day of the week ?""No." "The day on which I last visited her ""- "No."-She said my last visit was on a Sunday, which was not the fact. I thou ght her powers of apprehension were defective as well as her memory. June 10th, $T$ visited her and questioned her about her property. She said she had made Dr. Shapter her residuary legatoe, "was that not the proper word ?" I asked Dr. Shaptor if a will were made, and he said it was. Dr. Shapter added "I should wish some alteration to be made in the will for my own sake."

Mr. Collier: Mr learned friend has made an attack upon Dr. Shapter, and

I think I ahall be able to show that he is a man of honour.

Mr. Smith said he had not mado an attack.

The Commisioner : I think undoubtedly that a statement has been mado- 
wo will not onll it an attaok-and it is only reasonable on the part of Mr. Collier that an explanation should be given.

Mr. Collier: It is an indireot attack, which is worse; and. therefore, I wish Dr. Buoknill to say all that pareed.

Dr. Bucknill : I make the statement, becanse I feel that it is only fair to Dr. Shapter. He told me this-although, when I drew up ny report and sent it to the Iords Justices I did not feel myself called npon to mention it. Mr. Collier: What was it he mentioned?

The Commissioner read the statement made by Dr. Buolnill- "I asked Dr. Shapter if she had made her will, and he said she had and had signed it. I aaked him when it was done, and he said subsequently to the visit of Mr. Sharpe, and that he (Dr. Shapter) wished some alterations to be made in the will for his own ake." This conversation took place in Dr. Shapter's cottage garden, on the 10th of June. My fourth visit was on the 11th June. Whenever I questioned Mines Frings about her will, it was only to see what her state of mind was. At this date I questioned her respecting her annual income and what the interest was, but ahe could not tell. I asked her what she paid for her lodgings, and she replied supposing I pay $\$ 100$ a-year - that is $\$ 50$ for the half-year, and $\$ 25$ for the quarter. She could not tell what it was per week. In speaking of the will she said Dr. Shapter was her sole executor. Miss Cousens said she had witnessed the execution of the will. I was surprised to find her deficiency in figures. At one interview she avid, "What would my poor mother say if she knew that they persecuted me for money." [Dr Bucknill then stated at considerable length several trials in conting money, to which Miss Ewings had been subjected. In wome instances so failed, but in others she succeeded with some dificulty. I At $\mathrm{my}$ diotation she wrote a cheque for $\$ 15,000$, but thinking it might not be a fair trial, as she might have thought it was only done to shew her power of writing, I tore the cheque up. Her manner at theee interviews was calm and possessed. After mentioning many other instances, in which she was tried with figures, Dr. Bucknill said "I told her that she made a bad hand ;" whon she replied, "I know you have a right to examine me, but you are very wind and patient." I asked her to read, and she read two or three sentences from the "Companion to the Altar," and "The Common Prayer." She said she hoped that she would be allowed to take the sacrament, adding that she was not allowed to take it while she was in the asylum, and that they tried to make her a Boman Catholic, but that she said to them "I am a member of the Church of Christ." She read seven verses from the Psalms, but she miscalled or omitted one-fourth or one-fifth of the words. I wrote a note to Dr. Shapter, and alked har to give it to that gentleman. I can't say whether she knew what I had rritten, but she promised to deliver it for me. During ang exsmination rospecting a visit on the 17th of June, the witness said I again subjected her to the figure test, and with the same result as in former trials, though if anything more favourable. She told me she had learnt the multiplication table, and said twice two made four, and twice three made six. She also said 20 pence made 18. 8d., and 30 pence 2s. 6d. She could not tell me the names of the persons at the asylum where she had been, nor the name of the asylum itself. I asked her if she could tell the time by my watch.

The Commissioner : Had she her glaseses on?

Dr. Bucknill : No Sir. It might have been owing to the want of speotacles, or to the illegibility of the dial, but I cannot say. The time was ten minutes to nine, and the light was good.

The Commissioner : It was a rather sharp test for an old lady of 80 .

Dr. Bucknill then referred to the examinations on the 21st of June, which were similar in character to former ones. Miss Ewings said she had been agitated by remembering that Haydock and Haddock were the same. She gaid she thought she had been with Miss Consens six months. She thought her income was or might be a $£ 1,000$ a-year. She could not tell what she had given income was or might be a $£ 1,000$ a-year. She could not tell what she had given to the Christian Knowledge Society, whether it was $\$ 600, \mathcal{E 1 , 6 0 0}$, or $£ 15,000$.
She could not tell the time on my watoh, it being in the middle of the day, and the time quite legible. The decay of mental powers may be set down as in part due to mania, and in part due to paralysis. If the paralysis only had ocourred without subsequent mania, the probability is that we should have found hor mind in a itate of doear without dolucion. 
The Coinmisgioner: Are you speaking with regard to her advanoed age.

Dr. Buaknill : No. It would be very unjust to argue with regard to a person 80 yearm of age, in the came way as with regard to a perpon of 40 years of ago. ohildhood."

By Mr. Smith : I think those two canses would be more hikely to produce the efieet of insanity in a person of advanced age. In feot I have no doubt of it Cross-examined by Mr. Collier : Dr. Shapter read to me the names of eorerai persons to whom Miss Emings intended to make legacies. I said "Will she peave you anything?" Dr. Shapter replied "Some trifling matter, perhapa." During the course of a conversation I understood that she intended to make: will, and I aaid to Dr. Shapter "Will you allow her to make a will while this question in pending " Dr. shapter said, "I assure you, on my honour, my intentions are atraight and honourable." Dr. Shapter said "She is in as sonnd tato of mind as I am" When I left Dr. Shapter I was under the bolief that ill wo will would Iot bo ando. I don I think Aoylum. I go farther and say I think she ought to be placed under the care of her friends. I do not think her mind is quite gone. I have examined her eight times, extending altogether over nine or ten hours. I wont into this enquiry with the thought that Mise Evings was sane, and have put down things with perfect impartiality. I had no desire to prove her insane. I went into the enquir in an impartial spirit. The witness was then cross-examined upon his evidemes 7 th Tines the would be cruelly treated. She several times repeated her acoount of the journey in a very consecutive manner, and this goes to a certain extent to prove that she was of sound mind. Her loss of memory and her misstatement of facts were evidence as far as they went, that her mind was unsound. She stated that she rode in a second-class instead of a first-class oarriage, and also that she was put feet first into the carriage. Upon the first intervie alone I would not venture to say that she was of unsound mind. Nothing then passed sufficient to determine the faot. By itsolf imperfect memor is not s proof of unsoundness of mind. On the first interview Miss $\mathrm{E}$ riner mas agitated when I first went into the room, but afterwards became tranquil. She seemed to have a fear of "those people," meaning her relatives, taking her to an asylum. I am not aware that she knew that her liberty would depend greatly upon my report to the Lords Justices. I stated in my report that she lived in "dread of this event," meaning thereby her removal to an asylum. The lenowledge of my reporting to the Lords Justices would tend to make her nerrons, and themby afiect her calonlating powers; but I may state as fact that ohe not nerrous. She did not complain of my questioning her about mones calculations. At the asked her how much $\$ 100$ a-year amounted to per week, but sho could not tall me.

Mr. Collier: Can you yourself tell ?

Dr. Buoknill hesitated.

Mr. Collier : Don't be nervous ; take time. (Ianghtor.)

Dr. Buoknill : I dealine to tell you.

Mr. Collior : You wont or you can't?

Dr. Bucknill : I decline.

The Commissioner : I almost question whether the learned connsel himself

could have told unless he had been instructed. (Laughter.)

Mr. Collier : Do you generally ask sueh pursling questions.

Dr. Buchenill : No, but it was not done to puzzle her.

Mr. Colliar: Was such a question likely to produce a soothing and tranguilising offeot? (Laughter.)

Dr. Buoknill : Certainly not.

Be-examined: When $I$ had the first conversation with Dr. Shapter he said "I give you my honour that my intentions with regard to this properts are straightforward and honourable," and I believed him. To a casual obeerver there would bo nothing in Miss Bwings's manner to indicate unsoundnees of mind. By the Comminaioner: Judging from my last interviow on the 21st of June 
last, I should say that she was of unsound mind. I should call her unsoundness of mind a mixturo of chronic mania and dementia. Speaking in popular language I should oall it a mixture of mania and fatuity, ocourring in a person who once had a sane understanding. Her age and paralysis might be concurrent causes. The death of a beloved relative occurring to a person whose mind was already enfeebled by these two causes, might tend to bring on an attect of conte mental disease-mania, but the sister died seven years before the attack of paralysis.

The following is the conclusion of Dr: Bucknill's Report to the Iords Justices on the mental and bodily state of Miss Phoobe Ewings :-

"Your Lordships will perceive from the above recital that it is impoesible for me to concur either with those witnesses who believe that Miss E vings is in the full possession of her faculties, or with those who consider her quite inooherent or imbeoile. There can be no question that she mafered an conto attack of insanity in December last, and during the early part of this year. Her present state appears to be that of imperfect recorery. The attention, the present state appears to be that of imperfect recovery. The attention, the
memory, and the general intelligenoe remain to a certain extent permanently damaged; but not so far as to prevent Miss Ewings from taking part in society, or to justify the slightest interference with her personal liberty. $\mathrm{It}$ is imposesible for me to say how far the suspicion and dislike whioh Miss Ewings ontertain towrards her relatives are the result of unsoundnees of mind. The only indications that they are so are to be found in her unfounded belief that $M$ Fllecombe placed her in the arylno and in her great and constant far that sho the belief that at the asylum they attempted to make her a Roman Catholio. This belief was expressed to me in so cantious and circumstantial a manner that I thought it might possibly be founded upon some misapprehension of reality. I therefore wrote a letter to Mr. Sutton, the proprietor of the asylum, requesting was celebrated there. His reply in the negative, together with a letter on the subject from the Superintendent, to whoin I did not write, I transmit to you. On one point my examinations have been conclusive to my own mind, namely, that Miss Ewings is quite incapable of transacting business, or of managing her property. On the other hand I am convinced that any interference with her personal liberty would infliot much needless suffering upon her, and as she live: In dread of this event, I beg leave to suggest to your Lordships that if not inconsistent with your duties in this case, you should cause her mind to be at ease on this point without delay. Miss Ewings places the greatest confidence in Dr. Shapter and in Miss Cousens, and the fear that she may be removed frum them and placed among strangers or persons to whom she has unfriendly foelingm, embitters a period of life which all would desire to render as smooth and happy as oircumstanoes permit. At present Miss Ewings enjoys excollent bodily health. She takes long walks, and has a good appetite. To a person, however, of her age, who has recently suffered from paralyis and insanity, the probability of some recurrence of active disease of the brain is very great. I think it right to inform Your Iordships that Dr. Shapter consnlted me on thes procoedinge . state of mind on his statement, or to visit her, on the ground that your Lordehipis might possibly wish to place upon mo the duties of medical referee. I beg leave to suberibe myself."

Joseph Charlton Parr : I am a member of the firm of Messrs. Parr, Lyon, and Co., bankers of Warrington. Miss Ewings had an account at our bank: and when she left Warrington for Exeter, she had a balance of \$2,124 3s. 6d. and when she left Warrington for Exeter, she had a balance of \&2,124 3s. 6d. $\$ 2,335$ 18s. 6d. The sum standing to her credit on the 30 th of June, wres \&1,672 16s. - £663 2s. 6d. having been drawn out since the previous February. The account had remained untouched from the 24 th of November, 1858 , to the 15th of February last. In March we received an onder signed by Miss Evings, directing us to honour cheques drawn by Mr. Beamont. Wo have onls honoured one cheque since, for $\$ 18$ 28. 6d. Of the $\$ 663$, $\$ 500$ wes for the

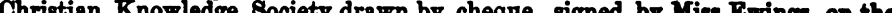
$28 \mathrm{th}$ of May. We were not surprised at so large an amount. I roodived the 

dividends on 87,307 in the now three per cents, and on $\$ 900$ in the three per

Cross-examined : In December, 1853, Miss Bwings and her sister gave \&500 to the Christian Knowledge Society ; and in November, 1868 Mis herself gave another $\$ 500$, making, with the $\$ 500$ in May last, $\$ 1,600$.

Dr. Charles Joseph Fox : I am the proprietor of an asylum for the insane at Brislington, near Bristol; and have been in practice nearly 30 years. I came to Exeter on the 10 th of March, and in company with Dr. Shapter visited to Ereter on the 10th of March, and in company with Dr. Shapter visited Warrington, lest she should be injured by her servants. She told me that she had been placed by "those persons" in the asylum. I referred to Mr. Fllacombe having liberated her from the asylum, but she seemed oblivious of that fact, and only mentioned her apprehensions as to her removal to the station. My interview was not with reference to my giving evidence to-day. The interview was so short that although I formed an opinion I declined to make an affidavit upon it. On the 21st of July I saw Miss Ewings again, the interview leoting an hour and a quarter. She received me kindly and oalmly. I told her I came at the request of Mr. Nicholson, of Warrington; and she polke of him and his family as kind friends. She first said Mr. Nicholson was a Roman Catholic, hut afterwards corrected herself, saying she meant her neighbour Mr. Ashton. She said she would not remain in her own house any longer but would rather remove to the parish workhouse as she considered herself in danger. She expressed great indignation against "those persons" who caused her to be removed to the asylum, though she said she had been kindly treated. Dr. Fox then confirmed former evidence so to the fears entertained by Miss Ewings respecting the designs upon her faith while at the Lanatio Asylum. I could not find out why she apprehended it. In her acoount of her resistance at the railway station, the reason she assigned was that she was placed in an inferior carriage., I asked about her property. I said is it $\$ 30,000$ ? and she said " $\$ 30,000$," repeating the words. I then said "Is it $\$ 20,000$ or $\$ 13,000 \%$ " She then said "Oh! $\$ 30,000$ is not muoh." When I asked her what would be the interest of $\$ 1,000$ at five per cent. she could not tell-I said $\$ 50$, and then I asked her what would be the interest of $\$ 1,000$ at two-and-a-half per cent., and she replied $£ 25$, and she added "the bankers only allow ine two-and-a-half per cent." I then said "If the cost of your boarding be $£ 3$ per week, what is that per month ?" She could not answer, so I repeated the question, but instead of answering it, she said " $M y$ income is more than I can spend." She could not tell me anything about the details of her property. I did not press her to get the details. She said that during her sister's lifetime she knew all about her money matters. I asked her what year it was, but she could not tell, nor could she tell me the dey of the month or of the woek. day of the month or of twice, but she atterwards addressed me as "Dr. Buckland." I put no questions to her respecting her will, but said "In case a person dies without a will the law provides for its distribution among the relatives," and she replied "I have no relatives." Miss Cousens was in the room throughout the interview, and Miss Ewings frequently appealed to her for an answer to my questions. I had an opportunity of forming an opinion about the state of Miss Ewings's mind, and I came to the conclusion that she was of unsound mind, labouring under dementis consequent pon it highly improbable that her health would be restored. Jane Warren, who was the attendant, told me "she was not out of her mind."

The Commissioner: That is not evidence.

Cross-examined by Mr. Collier: What I based my opinion of her insanity upon was her great incoherence, her very impaired memory, and her difficulty of comprehension. In no instance do I recollect that by repeating my questions she could give me an answer. But I will not swear that such was not the case. I do not think that simply looking at the fact of her repeating my questions was a conclusive fact in itself. I could not get any connected statement of the occurrences at Wanington before her removal to the Haydock Asylum, nor the names of any one connected with her, but she Haydock Asylum, nor the names of any one connected with her, but she spoke of them as "those persons." If she had been "lugged" into a carriage Ellacombe gave me an account of the manner in which she was treated, and I 
understand that she was not roughly handled. She could not tell mo the day of the week, nor recollect my name. I think that when I preseed her she tried to reoollect. She could not remember the difference between Dr. Bucknill and Dr. Buckland, though I do not attach nuch inportance to that. I think her memory must have been defective to forget the name of a person who frequently visited her. I did not question her, being an old lady, in the same manner as I should a person of greater powers. She knew Dr. Shapter perfectly manner as I should a person of greater powers. She knew Dr. Shapter perfectly is not unusual for old ladies to forget names and dates. She seemed to think that she was in danger from her servant. That was certainly a delusion. Upon my asking her the amount of her property she did not say she could tell the amount by calculating, but she did say that she could tell another day. When I asked her how much $£ 3$ a-week would be per month, I did not say whether it was a calendar or a lunar month.

It being now quarter past eleven o'clock the court adjourned.

SATURDAY.-SECOND DAY.

The enquiry was resumed this morning at ten o'clock.

Dr. Samuel Budd, who was the first witness, said I am a physician practising in this city, and am physician at the Devon and Exeter Hospital. I have paid two visits to Miss Ewings with the view of ascertaining the stato of her mind. The visits were on the 5th and 6th of the present month. I made notes of the questions, and the answers show strong evidence of the state of her mind. At the first interview, on the 5th instant, I conversed with her about her property and found her ideas very indistinct. She had no knowledge of the funds and could give no account of her property; she could not tell where it was placed, she thought it was in the Savings' Bank. She could comprehend nothing of principal cr interest. I said to her " When you want to buy anything where do you go for money "' She told me she had money in her purse, but knew not how it got there. She said at last when she awoke in the morning she found it there. I said "Supposing all that money spent and gone where wonld you go for more?" She said Dr. Shapter would give and gone where would you go for more "s " "Ife said Dr. Shapter was unable to give you any what would you do then?" She then said, shedding tears, she supposed she would then be obliged to go into the workhouse. Miss Cousen was present. After remaining with her some little time her excitement subsided and she laughed and seemed to enjoy herself. She shook me heartily by the hand. The interview did not seem painful to her. There was nothing peculiar in her manner. My interview lasted about an hour. The next day 1 paid her a shorter visit. Her manner was not strange. She shook me by the hand and seemed to remember me, though she did not recollect the time of my previons visit, but seemed to think it was on the previous night. On the 6 th I first spoke of the weather. It was raining hard, and she said, "The rain will do a good deal of good to the harvest and make the corn swell out;" she said that during the hot weather she had been very well. I said the season of the year had arrived when we must expect the heat to abate, and she said, "October and September." She said the present month was September, and that she came to Exeter in October. She said first that she was born in Lancashire and then in Devonshire. I said "Do you know Mr. Ellacombe?" Lancashire and then in Devonshire. I said "Do you know Mr. Hilacombe?" She replied "No." "Is he not a relative of yours ?" She answered "No." She added "I have heard of such a man, but I never saw him." I sajd "Did, he not take you from the asylum in Lancashire and bring you to Exeter "? convinced me that she is in a state of imbecility, and that she is quite incompetent to manage her property or to transact business. She is sufferin from dementia. I should be quite surprised to hear that after an attack of paralysis, and an attack of acute mania, a lady at such an advanced age came out quite unscathed or recovered her mental faculties in their integrity.

Cross-examined by Mr. Collier : I should be rather surprised to hear that an old lady of her advanced age, should, after an attack of paralysis and dementia, walk several miles a-day. I understood that I was employed by the court. I was aware that there had been a petition for a commission. I preferred being employed by the court rather than by the petitioner. I consider that I an her on the part of the court. I communionted the notes I made 


\section{XVII}

to Dr. Bucknill, and I thint I sent a copy to Mr. Daw, the attorney for the petitioner, but not to the attorney on the other side, though of course I should not hesitate to do so. I put down the answers which I thought would be evidence. There were many $I$ did not take, and many which were of a negative oharaoter. I should think it was imposeible to converse with her ten a negative charaoter. I should think it was imposen

Mr. Collier: Do you agree with Dr. Buoknill that a person might converse with her for a hour and a-half without being convinced of her unsoundneas of mind?

Dr. Budd : It is not my impression. I do not think you could converse with her for an hour and a-half without seeing it. It is probable that her condition will not improve.

Mr. Collier : Of course it is not likely that a lady at 90 jears will be brighter than a person at 80 years.-Dr. Budd : I will not say that her condition will materially alter in a month. I do not think she made hundreds of answers to my questions. I conversed about the weather, \&o., on both occasions.

Mr. Smith : Did you romark anything peculiar in Miss Ewingse mannars?

Dr. Budd : No ; I thought her manners pretty good

Mr. Smith : Could a person sit at table with Miss Ewings for a certain time, and uniess his attention were directed to her mental condition, might he go avay without disoovering that she was of unsound mind ?

Dr. Budd: I think it possible that she might pass muster under such conditions. But it is a very thin crust which in her case sustains the ordinary amenities of social life, beneath which lie the mere ruins of a mind.

By Mr. Collier : I cannot say that she liked being "trotted" through her property. I dare say that she knew the object of $\mathrm{my}$ visit. Sho did not appear to know anything respecting the funds.

Mr. Collier: Why did you ask her then ?-Dr. Budd : I first asked her if she had money in the funds, and I found that she did not know anything about them. I cannot say that those were the terms. I did not ask her directly them. the funds were. I cannot recollect all her answers. I will not swear what what the funds were. I cannot recollect all her answers. I will not swear what said, "Is it in land?" but I will not swear one way or the other. I have not a very distinct recollection. might.

By the Commissioner: I have no belief on the subject but probably I

Cross-examination continued : I have no recollection that she said "It is not in land, but it is in the bank." I will not swear that she did not use the words. She told me that all her money was in the "Savings Bank."

Mr. Collier: I ask you if your recollection is so olear that you will swear that she did not say so.

Witness : I thoroughly believe she did not. I did not say " What are the funds "" or at least I don't thikk I did. I will not swear positively that I did not. My recollection is not 80 clear that I will swear to every word used during so long an interview. I did say she had no distinct idea about property and income. She appeared not to be able to drap the inference that if she had money in the funds or anywhere else it would bring her an income. I did money in the funds or anywhere

not put any direct enquiry upon it. Mr. Collier : I um asking you what are your p

Witness : I did not ask her any direct questions on these points but I give you what I inferred. I don't think $I$ asked her if she was in the habit of going out and buying things in the shops, and paying for them. I think she might be capable of going about to shops, and paying for articles, and taking the change. She would know that a penny would bay a bun. and taing a wount she would do shopping, bnt anybody might easily cheat her. To a shight amount she would do shopping, bnt anybody might easily cheat her. I can't say whether she would ask for discount, but I think she might be taught to do it parrot-like. I did not know that she had some money in the "Ravings Bank." I said, where is your money placed? and she said in the "Savings Bank"

Mr. Collier: That she told you. You said before "all the money" was in a bank, and you said what bank, and then she replied "In the Savings" 


\section{0x}

Bank " - Witnees: I can't gay that she used the word "all"-bat my imprescion was that she did. I asked her where both her property and her money were pleced, but I cannot recollect whether she or I used the word "all." Bhe told me that Dr. Shapter managed her affairs. She said "My lodgings are managed." It would not seem extraordinary that she received moner from person who managed her affairs. I think her condition shows a considerable extinotion of faculties. I did not detect any delusion. I did not find there were any signs of mania. Judging from what I saw, I should call it dementia. I saw nc signs of distinct mania.

Mr. Collier : Do you differ from Dr. Bucknill, who said that it was a mixture of dementia and mania ?-Witness : Dr. Bucknill said he had detected delusion.

Mr. Smith : You may ask him his opinion, but not whether he differs from Dr. Bucknill.

Witness : I give you the result of my impressions upon her mental state from my own observation only.

Mr. Collier: I want to know whether you doctors agree or differ becsuse we have to judge between you. Do you think it is a mixture of chronic manis and dementia? Do you agree with Dr. Bucknill upon that ?- Dr. Budd : I suppose I must differ so far, that he observed what I dio not. A person who has a delusion may not show it. Yon may have to seek for it. It does not alwsys come to the surface. I consider her, judging froin my own observation, to be in state of dementia. I did not detect the signs of mania; and, therefore, so far as that goes, I suppose I must differ from Dr. Bucknill.

By Mr. Smith : I decidedly think she did not know the nature of discount, zo. Her condition may differ from day to day.

Dr. Harrington Tuke : I reside at Manor House, Chiswick, and am Superintendent of a private asylum at that place. I have devoted my entire attention to mental diseases for 18 or 19 years. I was requested to visit Miss Ewings. I saw her on the 10th instant. I was introduced by Dr. Bucknill in the presence of Dr. Shapter and a young lady. I did not understand her to be Dr. Shapter's governess, but learnt so subsequently. Dr. Shapter went be Dr. Shapter's governess, but learnt 80 subsequently. Dr. Shapter went away in a few minutes, and I was left with Miss Ewings and Miss Anthony. Finding that she was tranquil and calm, I suggested that Miss Anthony should leave, but she went up to Miss Ewings, and said "You don't wish me to losve, faet. I mentioned this to Dr. Shapter, and he said it would naturally be so on the introduotion of a etranger. Afterwards it became tranquil, and oo 7 as har

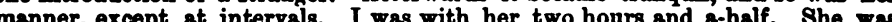
perfectly agreeable to git with me, and I think I could have sat there all day. I several times asked her if I tired her, and she said "No." She said Dr. Bucknill never tired her. I said "I thought you were ill after two interviews;" but she replied, "Oh, no." I put this several times, and she said positively, "Oh, daar, it was not so." 1 found her very rational upon some things. She retained considerable power of mind both as to memory and facts, but it was nncertain power. It was deranged in its action. Sometimes there seeemed to be an absolute want of memory; the general answers evinced a want of the power of comprehension. I asked her who was the reigning want of the power of comprehension. I asked her who was the reigning sovereign. She did not seem to understand the question. I said, Who hoverns the country, but don't hurry yourself ; I want to know who is the could think of, but she seemed unable to understand it. But the other lady very kindly interposed, and said "Who is the present Queen?" Miss Ewings immediately said, "Queen Victoria to be sure."

The Cominissioner : I think she beat you in your question.

Witness : The governess knew that Miss Ewings was aware of that fact, becanse she had heard her say s short time before that Queen Victoris was becuse she had heard her say a short "wo is this lady "? and she said Miss ahapter; when Miss Anthony said "you mean Miss Anthony." Miss Ewings had been addressing Miss Anthony as Miss Shapter during the conversation. She answered many questions pretty well when they were put slowly and carefully. I asked her the day of the week, month, and year, but all separately. She said it was Thursday, whereas it was Wednesday; she also said it was the J2th of September. I asked her the year of our Lord, she said 1839. The 
governess said you mean '59. I again expostulated with Miss Anthony, but it was not done by her offensively, although it interfered with me. I asked her the above questions at different intervals, five times begging her to take time to answer them. Each answer was wrong, although I carefully told her each time. Sometimes she said it was March, and at others September, but never Angust, although I told her it was the harvest month, and she said it was her farourite month. Twice she shed tears, and several times laughed; tears on account of her state of thankfulness to Almighty God for her then state of happiness, and also when she mentioned the death of her sister. she laughed once very heartily. When I mentioned the subject of money, she she laughed once very heartily. When I mentioned the subject of money, she of her property, and she replied, with great hesitation, $£ 13,000$ and then 8700. She then asked "Is that right"" I said I could not be snre, but I thought it was. I asked her how it was invested? Those were my words as near as I can recollect; where it was and how much it produced. I asked those questions singly, but could only get an answer to the last, she said I am sure she did. I said I thought it was right, and that she noed not trouble herself. I was very anxious not to put her through diffioult calculations. She herself. I was very anxious not to put her through diffioult oaloulations. She said she did not think she could write a cheque. "Do "Dou know what a cheque
is ?" She did not. Do you know what a draft is? She said, "Yes. It is a ways what I signed when I went to the bank to get my money." "Do you gign such things at other times "" "No, never." Did you not write a cheque for Dr. Buoknill ?" She denied it and asked the governess, who said she had never heard of it. Miss Ewings then seemed convinoed she had not. "You must have written cheques for Dr. Shapter"" I said this slowly over and over must have written cheques for Dr. Shapter?" I said this slowly over and over again, but she denied it. It suddenly occurred to me that I reoollectod the amount of the last cheque and said "Did you not give a cheque for 230 " " She had no recollection of it, and positively denied it. It was an extraordinury said-" Yes $\$ 500$ to the Christian Knowledge Society," but she denied as to any other. She could not state what her expenses were, but that they wert paid once a fortnight. I asked her if she paid her bills with the $\$ 12$ (the money in her pocket) how long it would last her? - She had previously and she had that sum. She could not answer the question. I could not get any reply as to her expenses, she never looked at the bills. She said when her sister was to her expenses, she never looked at the bills. She said when her sister was fortnight. She counted 112 10s. well. She said she did not pay Dr. Shapter because he was her friend and protecter. I said "What does he protect you from "' and she said. - "He is my protector, at my age I want a protector." I said have you not relations, and she answered " None at all" "No second or third oousins ?" "Mr. Ellacombe?" The suggestion of the name came from the governess. Miss Ewings said she would not have anything to do with him. This she said angrily and added, I would send him out of the room if he came into it. I expostulated with her. aking her reasons. She said she had been oruelly used and that Mr. Ellacombe had sent her to an asylum. I had been oruelly used and that Mr. Ellacombe had sent her to an asylum. I her what motive she thought Mr. Fllacombe had, but she did not soem to understand the question. At last she said-" It must have been a bad motive of Mr. Ellacombe"-She told me a long story about her journey in the railway carriage. She said her feet were placed foremost. She stood up desiring the young lady to hold her shoulders, and take her feet up as indicating the way a person would be carriod. Believing it to be untrue, I repeated it; and she a person would be carriod. Believing it to be untrue, I repeated it; and she but she could not mention the name of the place. I asked her who paid the expenses. She answered "I did not, and my lawyer did not." She said she was well treated, that she had a fine room, and that it cost her nothing." She then laughed most heartily, seeming quite to enjoy it. I asked her about her house, but she said she did not know anything about it. She said the furniture was taken to the bank. I said, "You don't mean the furniture ?" and she replied "No, no, I don't know where it is." She then gave me a long account of hur journey from Warrington. It was coherent, but I did not think it was true. She said that she rode in a seopnd-class carriage, and that I found to be untruu. 
By the Commissioner : I asked her now much money she had, and she replied that she did not know. Witness : I asked her if she went to the bank would they give her any money she asked for,and she replied "Yes, they would give $\mathbb{S}_{5}, 000$ or $£ 10,000$. Would they give $£ 20,000$ ? I said. She husitated, and gaid
"I should never ask for so large a sum." I then asked her about her will. Sho said "I have made my will ; it was ny own act and deed." I asked her as pently as I could how she had left her money, and she said she had given some legacies to servants, and $£ 500$ to the Christian Knowledge Society. She said she had a great many legacies given to her. I said "What have you left to Dr. Shapter "' She could not tell. I inferred this, as she did not answer. Considering this very important, I suggested various sums to her. Have you left him more or less than 2500 ? She said "I cannot tell." I am quite certain about the words. I said "Do you know you have left him a handsome fortune." She said "Yes, it may bo ; he is uy friend and protector." This conversation ocoupied some time. I asked her about her illness, whether she had been ill. ocoupied some time. I asked her about her illness, whether she had been ill. paralysis "" She never had been ill." I said "Hove you never hand an attack of could what the attack was, and she said "No, thank God, I have never lost in sense of sight, my speech, or any of my senses." She seemed angry, and said, what will they say next? I apologised, saying, I had information from her own medical attendant, Mr. Sharp. She was angry and agitated, and said "It is impossible." I asked her whether she had ever suffered under " nervous derangement." I said this as delicately as possible. She said "Never." She said it as if the thing had never occurred to her. I said, you have been in an said it as if the thing had never occurred to her. I said, you have been in an
asylum. She said "Yes." I said "No one can be put in an asylum without a certificate of mental derangement. She said "It was quite absurd. Me ever insane? quite absurd." I asked her if she believed in the Roman Catholics, trying to make her a papist. She said "No, never." But you surely have said so previously? She said "No, I never have." I mentioned Dr. Sharp's name, saying he might have thought you ill and signed the certificate thinking She said Dr. Shapter never gave her any medicine, he came to see her only as a friend. I said had you not 100 guineas in your stays when you were taken to the asylum. She said "I will tell you all about that." This story of hers, like others was told at length, but very difficult to get at in consequence of her "rambling manner." It was very difficult to get at her meaning. She said sho believed people were coming in and going out of her house improperly, but she could not say what people, only she was sure they were there improperly and that they were flurrying her, and therefore she put all the money in her stays. That she was frightened, and added "Life you know is very dear to me." I asked her if she was frightened of her life, and she said no, only she was afraid of the house coming down. The people came in and out, she was then seired and oruelly used, and then taken to the asylum. She showed me again how she was put in the oarriage, which was the same way as before. Mr. Sharp, she said, was not present. It was her own servant who held her. I could not succeed in obtaining who it was had cruelly used her. I examined her to the best of my ability. She said she never read the newspaper, but at my request would try to do so. I handed her the paper, but finding that she was quite bewildered, so do to make nonsense to the listener by misplacing words, I said, "Oh, I will read it then." The governess said "It is beonuse her hand shakes so," but I gave upld me that she liked Dr. Bucknill very much, and that he was coming to see her that afternoon. When I took leave of her she evidently seemed to misunderstand who I was, I said I hope this long conversation has not tired you and she said "No, oh dear no. It is so kind of my friends to come and see me." At other times she seemed to know me, and the object of my visit. She was excessively kind and affectionate, sitting by me and holding my hand, but this might have been through my trying her pulse. The other hand olasped that of the governess. I do not like to forin a judgment upon one visit, and applied for leave to make another, but was refused. I formed an opinion of the state of ber mind. I think she is of unsound mind, and incapable of managing herself and property, but wish to be distinctly understood that in her present state, she should not be placed in an asylum for the insane, because I think she might be taken care of out of an asylum, and her delusion about strange peoplo would 
be increased by the presence of other patients. To the question do you beliere strange people had been in your house improperly? she told me that she still thought it was so.

The Commissioner : To what category do you refer her disease ?

Witness : It is difficult to refer it, I consider it to be weakness of mind, following as it constantly does, either paralysis or acute mania but there is some chronic delusion, and in technical language I will say it was the first stage of dementia.

By Mr. Karslake : Loss of memory, and inaccuracy of dates and facts and names are often con zequent upon paralysis, not so of ten the result of mania.

Bythe Commissioner : Attajks of paralysis in the caso of a person of so advanced an age are generally fatal.

The Commissioner : Supposing delusion to exist, is it more likely to be due to acute mania than paralysis?

Witness : Probably acute mania and not to paralysis. The loss of memory and the errors as to dates, facts, and names, which I observed are in my judgment the result of deranged action of the brain, and not the result of old ago alone.

Dr. Tuke, eross-examined by Mr. Collier. He said : I wished to see the old lady again, but I had not the permission. I came here on Tuesday, hearing that her medical attendants did not wish me to see her on Thursday, the das before the oommission; but I saw her only on Wednesday, and could nof see her on the Tuesday.

Mr. Coleridge explained that it was in consequence of the legal gentlemen being absent at Wells.

Cross-examination continued : I would strongly advise your side, as you call it, not to produoe her before the court at all. Upon a hypothetical oase, 1 should say it would be better that she should not be examinel by a me tic.l gentleman the day before tife commission. I mean to say that a conversation of two hours the day before the commission. I mean to say that a conversation of two hours and a-half conducted in the way $I$ did, would not have injured her. I tried
whether it injured her physically, and think it did not. Upon my oath it did not confuse her, for at the end of the conversation she sesmed more alert. In cases of feeble circulation it would act as a stimulant. Her defects arose in some degree from weakness or feeble circulation. There is a difference between weakness through too little circulation and madness. Her loss of meinory, dates, \&c., might be owing to a feeble circulation through the brain, and I think I may attribute part of her symptoms to feebleness in the circulation through the attribute part of her symptoms to feebleness in the circulation through the She might be better after dinner than before, or after a little wine, but it might act the reverse, but so far as my observation went it did. I think her very extraordinary and marked mistake as to persons, is one symptom of derangement of brain, and not old age. One mistake was calling Miss Anthony Miss Shapter. Another feature was her persistance in the mistake of names, which is a sign
of the decay of tho brain. I should not say that it showed "derangement" though.

By the Commissioner: Miss Anthony is a young lady.

Examination continued : She talked of several persons being at places where they were certainly not. The two things, names and places, are in my opinion the same. I should not think it derangement if she said Ellacombe instead of Nicholson. She used the word "workhouse" for "asylum." When she said "workhouse" the governess said you mean " asylum." This she said frequently. I am aware that this asylum was a place where paupers were, but she certainly confused her ideas about two places, so that her conversation was quite nonsense. I think she knew what " asylum" was. An old lady might be oblivious of dates dr., without being derenged, but after I had told her four or five times she could recollect. If I see there is a person that cannot understand " Wednesday" when recollect. If I see there is a person that cannot understand "Wednesday" When down those questions which $I$ think bore upon her unsoundness of mind. The two hours and a-half were much taken up by the conversation of the lady herself and Miss Anthony. I have put down what might be evidence of soundness of mind. I asked her if she was afraid of the "French invasion," and she said "No"" There were several questions which she answered most correctly and like a person of sano mind. I know that if an old lady is interrupted when 


\section{XxmI}

telling a story she is "put out." I asked her several questions about the head of the Constitution.

The Commissioner : If you were to ask Mr. Roebuck who was head of the Constitution, he would say the House of Commons. (A langh.)

Mr. Collier : To witne is. Who administers the law? A: I don't answer. $Q$ : You complain of a question you put to a lunatic and yet when put to joursel you say it is not plain enough. A : I don't understand you. (A laugh.) $Q$ : I put it to jou clearly enough. Who rules in this country? A: The King or the Queen. Q : Should yon say it is the Queen or the Chief Justice of England who administers the law? A: I should have said "It is the Queen." $Q$ : Who administers the law? A : I should have said "It is the Queen." $Q$ : What would you say upon consideration ? Mr. Montague Smith interrupted.-
Mr. Collier : There is no commission upon you. (A laugh.) After being further Mr. Collier : There is no commission upon you. (A laugh.) After being further
pressed the witness said this question might not have been put in the most pressed the witness said this question might not have been put in the most
proper manner. After a variety of questions the witness said that one of her symptoms of insanity was her morbid aversion to Mr. Fllacombe, the reasons she gave being insufficient. "Ii an old lady gives me an opinion founded upon insnfficient reasons I do not say it is morbid" I, therefore recal that answer. The dislike to Mr. Ellacombe was exaggerated and untrue.

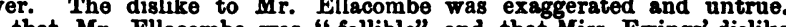
to him was just her behaviour to him, would be explained. If she had no wish to 80 into the train, and Mr. Fllacombe ordered her to be put in by porters, it might account for her dislike, but she had "condoned" the matter. Mr. Collier : We are to snppose we are in the Divorce Court.

Cross-examined : I believe that she was very happy and contented at Mise

Consens. Mr. Ellacombe wishing to remore her might have sccounted in part for her dislike, and especially when he said you " must go." Still I think it was a morbid opinion as she had no cause of complaint against him. It did not a morbid opinion as she had no cause of complaint against him. It did not of paralysis. I told her that Dr. Sharp had said she had had an attack of paralysis. When I told her of it she was much excited and was angry, and said, "What will they say next?" I presumo that she said about losing speech, sight, \&c., from my explanation of paralysis, and then she said "I thank God." On my oath as a medical man it did nót alarm her. She then said "What will they say next." I don't think it is right to conceal from persons of old age that they had an attack of paralysis.

The learned Commissioner : It might embitter or poison the rest of her life. Dr. Tuke : I am very sorry that I mentioned it at all then.

Cross-examination resumed : I said it was the first stage of dementia, I do not think it right to put me in the box upon a conversation of two hours and a half.

By the Commissioner : I do not think Miss Ewings is likely to recover.

This was the last witness for the petitioner; and Mr. Smith applied that the original instructions for the will and the will itself shonld be put in as evidence. Mr. Collier objected to put in the will, as great difficulty might be experienced supposing Miss Ewings was not found to be a lnnatic. The instructions were broken up when the will was signed.

The Commissioner agreed that there would be difficulty in putting in

Mr. Karslake then summed up the evidence for the petitioner, contending that it provea the unsoundness of Miss Ewings's mind, and her incapacity to manage her property.

Mr. Collier then addressed the jury. He said this was an extremely painful enquiry, and one that was altogether unnecessary. There was not the slightest necessity for disturbing the few remaining years of this old lady's life. There necessity for disturbing the fow remaining years of this old lady's life. There was no reason whatever why she should be questioned and cross-questioned by a
number of mad doctors. What was her state according to the evidence of the nnmber of mad doctors. What was her state according to the evidence of the
petitioner's own witnesses? She undoubtedly had an attack of paralysis, and petitioner's own witnesses? She undoubtedly had an attack of paralysis, and that time Miss Ewings had come to Exeter, and according to the petitioner's witneeses she was now perfectly confortable with Migs Consens. What had he done that all these proceedings ohould be taken against her? Had he ore ever injured anybody? Had she ever acted like a mad woman except at the time when she was taken to the asylum? Why then had these proceedings been
taken? The answer was this, that Dr. Greenup, towards whom she had all her 
$\operatorname{xxr}$

Life entertained a well-founded aversion, wanted her money. The question that was now being tried was in effect the case of Greenup $v$. Ewings. Dr. Greenup's family some years ago had instituted a ohancery suit against her branch of the family some years ago had instituted a ohancery suit against her branch of the Greenup's own evidence he had only seen her once before during his life, and yet he came down to Exeter, searched her out and then commenced these procoedings, which had the effect of torturing the old lady. He (Mr. Collier) regretted the manner in which this case had been conducted. It had been managed like an ordinary nisi prius canse - the only desire of the petitioner being, by nisi prius manoeurres, to obtain a verdict. What evidence had been produced?

There was Dr. Holland, who was brought all the way from Norwich to state that in 1853 Miss Ewings behaved rudely to him. The fact was that her sister died in October, and Dr. Holland went in the following May to condole with her. His learned friend (Mr. Smith) was going at great length into her condition some years ago ; but the learned Commis:ioner very wisely suggested that the question in which the jury was more immeliately interested, was her inental condition since she had been in Exeter. Why had they not called M iss Cousens, with whom she had lived here? If they had been sincere in their desire to throw any light upon the oase, they would have produced that witness. Instead of doing that, they had called a number of mad doctors, who were always looking out for insanity, and beating about the bush to find madness. He hoped the jury wonld bear in mind the warning contained in the learned Commissioner's jury wonld bear in mind the warning contained in the learned Commissioner's grandmothers, and aunts, if their faculties were to be tried by mad doctors. The opposite side had designedly withheld Mr. Sharp who had been for 30 years, the medical attendant to Miss Ewings. Dr. Bucknill adinitted that that gentleman's evidence would have been important; but nevertheless ho had not been produced, and the reason was that his opinion did not agree with that of Dr. Bucknill. Evidenoe had boen given to show that she was much distressed at the death of her sister. He (Mr. Collier) conceded to his learned friend that she did grieve at the logs of her dear relative; he gave him the full benefit of all the madness which he could extract from grief at her sister's death. He (Mr. Collier) believed be should be able conclusively to show that since Miss Ewings had left the asylum she had perfectly recovered. Mr. Collier then went on to state that he should call Mr. Sharp before them. What was the manner in which the case had been brought before them? The other side had come before them (the jury,) saying they were only desirons of affording every information. They repudiated the idea of trying to get a verdict against Miss Ewings, but that the enquiry was only for her benefit. And yet they withheld from them the most important information they could give them. He (the learned counsel) the most important information they could give them. He (the learned counsel) would enquire how the case had been conducted, before he disclosed to them the
evidence which he should bring before them. His learned friends had carefully avoided calling before them persons who had ever had dealings with Miss Ewings in Exeter. And by giving theun no information whatever themselves upon the manner in which her affairs were conducted, they contented themselves by calling medical gentlemen, who were perfect strangers to her, gentlemen who formed their opinions partly upon what they said and partly upon what they heard. The first medical gentleman was Dr. Bucknill. This guntleman had made a very lone frst medical gentleman was Dr. Bucknill. This guntleman had made a very probably if the jury had read that report thenselves they would have onme to conprobably if the jury had read that report thenselves they would have come to conand he thought his learned friend had thought so to - that they were not at all anxious that the whole of this report of Dr. Bucknill's should be read to them (the jury). It was his desire that the whole of the report should have been placod before them, because he thought that it would show that this old lady was never marl at all. They had not the opinions of the medical gentlemen only, but the premises upon which they founded their opinions. They could, therefore, forn their opinions upon those premises as well as npon the opinions of the forn their opinions upon those premises as well as upon the opinions of the
medical gentlemen themselves. He did not know that dealing with lunatics medical gentlemen themselves. He did not know that dealing with lunatics
strengthened the logical powers and bestowed powers of reasoning. The doctors said, "Wo think she is a lunatic because of this, and that, and so on." But we were able to judge as well as they could, and we could draw our conclusions. He the learned counsel) invited them to take notice of the premises, and he had no doubt that they would differ from them in their conclusions upon these said 
premises. He had throe or four medical gentlemen, of the highent respectability who would be put before them, and who would entirely differ from Dr. Bucknill and the other medical gentlemen called by his learned friends. They would tell them that they thought the lady quite capable of managing her affairs at the tell them that they thought the lady quite capable of managing her affairs at the
present moment. He would beg their attention now while he went into detail present moment. He would beg their attention now while he went into detail
upon the evidence. With respect to the evidence of Dr. Bucknill, that gentleman expressed a somewhat hesitating and qualified opinion upon the matter. Ho thought he was allowed this observation with respoct to Dr. Bucknill's evidence. The case seemed to have puzzled him a good deal. It was a long time before he could make up his mind that the old lady was inad. He examined her for one hour and a-half at the first interview, and he said very candidly that although

there were some indications of loss of memory, still if he had been called before them as a witness, after the first interview, he would have given his evidence in favour of Miss Ewings. That struck him as a strange fact. Here was Dr. Bucknill accustomed to discover insanity and trace it in its lurking places. He went to her for the purpose of discovering it with regard to Miss Ewings. Ho examined her for one hour and a half, and the result was that he could not form a decided opinion that her mind was unsound or that she was unable to manage her own affairs. That same gentleman tried her again and again, he believed her own affairs. That same gentleman tried her again and again, he believed ploasing to her, and that she liked it very much. He thought they would pleasing to her, and that she liked it very much. He thought they would be satisfied before the case closed that it was quite different, and that ghe
dreaded those interviews beyond everything. She knew but too well all that was going on. She knew perfectly well that there were those who wanted her moneg. She knew that proceedings had been taken against her in Chancery, insanity; and that upon the result of their verdiot depended her liberty aye, her life, and all the comforts of her remaining days. She knew it, and felt it painfully. She knew that Dr. Bucknill was a man of great power. She felt it painfully. She knew that Dr. Bucknill was a man of great power. She knew that he was an agent of the court. She understood that she was to be put as it were through her catechism, and that she would be sent
to school again. She knew the puzzling questions which were put to her, and although Dr. Bucknill and the other medical gentlemen did not mean it, yet it was their way of doing it. Why the poor old lady lay half awake with the multiplication table floating before her eyes in all directions. He dared an sho lay awake counting twice two aro four, twice throe aro aix twontypon laugh.) She really must have thought that she was to be put through a kind of catechism in this respect. When she was asleep some visions of the multiplication table were no doubt there topsy turvy or before her in some shape or other. (A laugh.) Talk of the ordeal of the plough share in olden times; this was worse. Upon that examination it did not depend whether she was to be admitted to degree, but upon it depended whether she was to enjoy her liberty for the rest of her life. She knew that it was so. She understood what it was to enjoy life, and she was apprehensive of the examination of those powerful men. He said that it was the very anxiety on her part to do well before Dr. Bucknill, which prevented her doing well. He had known very able men who were entirely broken down because of their anxiety to do so. A very able man in this state lay awake thinking of the examination, and through it he was "pluaked." He believed that she had been plucked by Dr. Bucknill. After further remarking upon this point, the learned counsel went on to say that he believed that when they came to examine her theinselves they would find that she possessed a great deal of knowledge, that would astonish all these mad doctors. A poculiarity of the disease under which the unfortunate lady suffered was then pointed out by Mr. Collier, who explained that its effect was some days to make in person able to transact business with comparative facility and again the reverse. The ovidence
of Dr. Bucknill, which he criticised with much ability, was then notioed, the of Dr. Bucknill, which he criticised with much ability, was then notioed, the learned counsel at great length contending that instead of being unfavourable to her favour. The differenoe in the testimony of the various medical witneseses was pointed out, and from it the conclusion drawn that one day Miss Ewings was depressed, which caused an unfavourable impression, and the next day was much better. It spole nothing againgt her total inceproity. In speaking of the questions which were put to the old lady, Mr. Collier aharacterised the majority 


\section{XXVI}

of them as too difficult, and quite sufficient to cause nervousness. He particularly alluded to the $£ 100$ a-year question put by Dr. Bucknill, who when asked himself the very question he had put to this alleged Innatic, what per wook is $\$ 100$ a-year, could not toll. Her answrers to questions about hor property they found exactly correct. What was it? $£ 13,000$, and then in a few seconds the second answer \$700. This was found to be the case; her property was $£ 13,700$. Then, what is your income? $\& 400$ a-jear. What was it? $\& 396$ ! Did this bespesk insanity? Upon these answers were they to found a verdict of insanity? After further reference to conversations, Mr. Collier directed the attention of the jury to the diference in the medical testimony respecting her actual mental condition. Dr. Bnoknill said she was of unsound mind, because she did not know her property, bent that was done away with by Dr. Tuke, who said she did. So they would find that they all differed more or less. He begged them seriously to consider the question. Dr. Tuke asked her about her will, and the property she had left the guestion. ohe might not have wished to tell, and only replied in that form by way of an evasive answer. But this was put down to her non-comprehensireness, and upon these premises they built their conclusions, and they said-" She is labonring under dolusion, and chronio mania." He believed that anything less like maniac they had never seen. She was no more of a maniac than either of them. Then they said, she is suffering under insane delusion and morbid aversion. Her aversion to Mr. Fllaonmbe was no proof, and yet they were told that it was. Acoording to Dr. Tuke it was evidenoe of insanity - not mere weakness from old Acoording to Dr. Tuke it was evidenoe of insanity-not mere weakness from old age-but derangement. The learned connsel then remarked upon the circumstances which probahly led Miss Ewings to entertain a dislike to Mr. Gllacombe. He thought it would turn out as complete a "mare's nest" as was ever imposed
upon mad doctors. Mr. Fllacombe thinking that he was next of lin took all upon mad doctors. Mr. Fllacombe thinking that he was next of hin took all not next of kin, his interest vanished. (A langh.) Mr. Collier then expressed his delight that he had to appeal to them- a tribunal of jurymen-instead of doctors - and had to ask them whether this lady was really under a delusion. It to the asylum. But the truth was that some force was used. She disoorered that she was being taken there, and she resisted, so that her attendants employed
some violence. Then with regard toRoman Catholics, it was an undoubted fact some violence. Then with regard toRoman Catholics, it was an undoubted fact
that there was an unusually large number of Roman Catholics at the Haydock Asylum - the proprietor having admitted that there were at least 50 . Another material fact was that the proprietor conld not swear that one of the lady inmates was not a Roman Catholic, and had not had communication with Miss Ewings, and that that lady was not in the habit of attending a Roman Catholic ohurch within half a mile from the asylum, and the priest was in the habit of visiting the asyluin. If all this were true was it was in the habit of visiting the asyluin. If all this were true was it
unlikely that some efforts would be made to convert her there? Roman unlikely that some efforts would be made to convert her there? Roman object; and we could understand that that object would be pursued even more eagerly when they were insane. At any rate it was clear that the whole thing was not a matter of the imagination. Miss Ewings was a strong protestant, and like many others sho entertained a dread of the Roman Catholics. Then with regard to Mrs. Barnsley, Miss Ewings saw that person at the railway station, and it ocourred to her that ghe was again about to be tricked, as she had been and it occurred to her that she was again about to be tricked, as she had been tricked before, when she was taken from Warrington to the Asylum, when sho
had seen Mrs. Barnsley. The party handed Miss Ewings over to a porter, who had seen Mrs. Barnsley. The party handed Miss Ewings over to a porter, who
bundled her into a carriage heels first. A porter was also placed by her side in the carriage, and it was not surprising that she thonght she was in a second clase carriago. He (Mr. Collier) in all his experience had never seen a porter riding in a first class carriage ; and it was quite excusable that Miss Ewings shonld be mistaken. Then it was stated that she did not speak to $\mathbf{M r}$. Nicholeon and $\mathbf{M r}$. Fllacombe during the journey to Exeter; but this was acoounted for, when it was remembered that she felt indignant at their ordering a porter to plece her in was remembered that she felt indignant at their ordering a porter to place her in that person, and her state of mind rapidly improved. Mr. Fllacombe was beged to leave her alone, as she had endured a long journey; but he called to see her the next day. He also went again three or four days afterwards. And what did he go for? Although she was perfectly comfortable at Miss Cousens ho told her 
that she must leave and go to another house. She thereupon took a dislike to him; and this the mad doctors called a proof of insanity. Thus the delusions when they came to be grasped disappeared. He did not impute anything wrong to Mr. Ellacombe, but his conduct at the railway station, and his desire to remove Miss Ewings, cansed her to dislike him. That was the kind of evidence npon which the medioal witnesses had formed their opinion as to her sanity or insanity. He believed he might have rested satisfied by replying to the case of his learned He believed he might have rested satisfided replying to the case of his learned friend on the other side. When the evidence of the witnesses was analysed their conclusions vanished. The alleged want of memory was to a great degree explained by nervousness and other causes. When the doctors dificas from their conclusions, he might well leave the case in the hands of the jury, feeling satisfied that they would say the allegation of insanity had not been proved. He satisfied that they would say the allegation of insanity had not been proved. whom the other side had withheld. In the first place he should call Mr. Beamo:tt whom the other side had withheld. In the first place he should oall Mr. Beamo!nt,
an old friend, who was acting as Miss Ewinge' solicitor. That gentleman would
give a short history of her case before she came to Exeter. This would not differ from the statement of the other witnesses as to the fact that when she was in the asylum she was suffering from manis or delirium. Mr. Beamont would further tell them that she had such a knowledge of her affairs as might fairly be expected from an old lady of 80 years of age. She was never a woman of business, or a woman of lgures; but she knew quite enough of her afrairs to be trasted also call Mr. Sharp her medical attendant, whom the other side were exceedingly anxious not to call. Mr. Sharp would tell them that her memory for a for years somewhat failed as regarded names and datos, a failing common to most old persons; but at the same time he believed there was no reason whatever for any interference with her liberty or with the management of her afiairs. Another witness would be Miss Cousens, with whom Miss Ewings had lived perfectly happy since she had been in Exeter. Miss Cousens would state that she had happy since she had been in Exeter. conducted herself like any other lodger. Ann Rattenbury the servant at Miss about Exeter, making small purchases, giving the right money and taking the right change. In addition to these witnesses, he should call Dr. Shapter, and in reference to that gentleinan he felt it necessary to make a few remarks. His learned friend (Mr. Smith) had disclaimed all intention of attacking Dr. Shapter, but he had nevertheless insinuated everything against him. The facts were these. Miss Ewings came to Exeter, but not at the solicitation of Dr. Shapter. Dr. Shapter had known her when she and her sister were here before in 1852 . Ther had corresponded with Dr. Shapter's sister, which continned till the death of the latter in 1858. When Miss Ewings came to Exeter, in February last, Mr. Ellacombe called in Dr. Shapter. Miss Ewings at once recognised him, and he treated her with great kindness. She had no relations about whom she cared a farthing; she disliked Dr. Greenup, for the reasons already mentioned, and she was also displeased with Mr. Ellacombe, who was a third cousin once reinoved. She had lost her onlv sister, and she had not a friend or a near relation in the world. Dr. Shapter behaved very kindly to her, and what was more natranal than that she should become attached to him? Any old lady of that age would require some one to take care of her; and Miss Ewings took a liking to Dr. Shapter. He knew this, and being a highly honourable man, and thinking that she might make a testainentary dispositiun of her property in his favour, took a most manly and honourable course. Ho felt that, however straightforward his conduct might be, and however free might be the disposition of the property, yet as a medical man, such an act might be reflected upon. To be free, therefore, from ill reproach he adopted a course than which none more honourable could have been parsued. He wrote a letter to Mr. Beamont, sending copies to $\mathbf{M r}$. Nicholson and Mr. Fllacombe, in which he expressed his determination not to scept any bequest that might oe made in his favour. A more unfounded attack therefore, than that inade by Mr. Smith had never been made on any professional man. Miss Ewings strongly urged him to become residuary legatee, and he only consented when he wrote those letters renouncing all benefit to himself. If, aftor writing such letters, Dr. Shapter had taken possession of any of the property, he would never have been able to have shown his face in Ereter again. An important fact connected with the will was, that Miss Evings did not resolvo 
XXVIII

upon making it until after the visit of Dr. Greenup. She knew that Dr. Greenup wanted her money, and she was determined he should not have it. She knew also that if she died without a will her property would go to him; and accordingly, as soon as he had left, she determined that the will should be made. These were the facts, and he anxiously hoped that the jury would not by their verdict deprive Miss Ewings of her liberty during the few remaining years of her life.

The learned Counsel then chlled the following witnesses:-

Mr. William Beamont, solicitor, Warrington, said : I have known Mis

Phobe Exings for more than 50 years. She lived in a house of mine for 30

jears. I have been on intimate terms with her. I am her attorney, but she has not had any law business since her sister's death on the 10th of October, 1853. Then I settled her affairs. Her mother died in my house in the year 1826 . Mr. Coleridge : Do you know that there has been an estrangement between the petitioner's branch of the family and Miss Ewings ?

Witness : I know it now, but I did not know it before. Miss Ewings frequently went away for a long time into Devonshire. On one occasion she was away for three years, and on two other occasions she was awsy two was away for three years, and on two other occasions she was awsy two years. She had lodged for a considerable time with Miss Cousens previous to the last occssion. I recollect Miss Ewings being much distressed at the death
of her sister. She withdrew at $t$ e time from society more than was thought wise. I tried to pacify her, and told her to go more into society. I always considered the elder sister had the entire guidance of all her affairs when she was living. I did not live in the house with them, but three doors below. I saw them constantly. I recollect in October last having heard that Miss Ewings had had a paralytic stroke. Perhaps it was a month after that time but I heard of it. When I saw her she appeared just as before. She appeared but I heard of trace of it in her body, but there was a little in her mind, and also her disposition. She seemed rather more melancholy than before. She appeared quite capable of discussing matters with me. I saw her on the 23rd of December at her house; I went there. She seemed quite as usual. I called on her as a matter of friendship. She was tolerably cheerful, more so than usual; she asked me to coine again. She was not at that time a lunatic. She talked to me abont my wife and all sorts of subjects the same as another old lady. me about promised to see her again in a week. On the morning of the 30th of December the morning on which I was about to visit her, I was fetched by Mr. Mould to go to Miss Ewings. I went and found there Mr. Mould, his mother, Mr. and Mrs. Wood, a Miss Harrison, an attendant, and a servant. Miss Ewings was very much exhausted. She remained at the window and called to the persons who were passing for protection. She complained of persons bein in the house. She complained also of her servant. I don't remeinber that she said anything but that her servant was dishonest, and that she was going to harm her. I did my best to pacify her. I succeeded in the conrse of two hours in getting her to sit dow. Mr. Sharp of Warrington was her medical hours in getting her to sit down. Mr. Sharp, of Warrington, was her medical
attendant, and I sent for him. He did all he could to soothe her, but without attendant, and I sent for him. He did all he could to soothe her, but without
effect. She had the belief that there was great danger in remaining in the house. She showed me her throst, and said persons had tried to strangle her. We all (eight of us) came to the conclusion that the best thing would be to send her to en asylum. I thought her decidedly insane. There was an interval of three hours before she was sent away. She was taken to the asylum in carriage. She $79 n$ t in the oarriage in the oxpectation carriage. She want in the carriage in the expectation that she was going to live somewhere else. Whilst she was in the asylum I asked Mr. Sharp to visit her and report to me. I wrote on the 31st of December to Dr. Shapter. I knew that a correspondence had taken place between Miss Ewings and Dr. Shapter, and that was the reason I wrote to him. In consequence of the letter I wrote to Dr. Shapter, I received a communication from Mr. Mllacombe. From time to time I received reports from Mr. Sharp, and I transmitted them to Dr. Shapter. I sent one or two of the reports to Mr. Fllacombe. On the 6th of February last $I$ received a letter from Mr. Ellacombe. In consequence of that letter I gent him a full report of hor case. Ho arrived at consequence of that lotter I sent hy my house on tho 11 th of myself the next morning to Miss Ewings. I never saw her after she left
Warrington until I saw her in Exeter. I heard of her arrival at Exeter 


\section{$\operatorname{xxx}$}

through Mr. Fllacombe. In consequence of a letter previously received from Dr. Shapter, I went to Exeter, and I there saw Miss Bwings. She was very seen her for several years past. In my opinion she appeared as if her mind was in no way afiected. In speaking of her business, she said "You like business, and I hope it will be settled for me." She then gse for $\$ 100$ for the payment of several debts. I filled up the cheque, and she signed it. She told me to settle with Miss Cousens about the expense of her living, and told me that I was to get the money when I wanted it. She said she did not want to be stinted, as she had property amounting to $\$ 12,000$; she gaid her income was several hundreds of pounds, and that was the reason she did not want to be stinted. At that time $I$ was not aware of the total amount of her personal property.

It being now half-past gix o'clock, the court adjourned till Monday.

\section{MONDAY.-THIRD DAY.}

The court resumed its sitting this morning at ten o'clock. The interest in the case was evidently undiminished.

Mr. Beamont was re-called. He said, Miss Ewings first said she thought her income must be about $£ 600$ a-year, but she spoke doubtingly. I told her that I thought it conld hardly be so much. I was some considerable time with her. I said " yes, madame," and she said she had told me three or four years before not to use that term, which was quite true. She showed me some letters received from her friends, and made some comments, which appeared quite just. One letter she said she should not answer, as she did not think the writer had behaved well to her. I think it was a just conclusion. It was a lady who wrote the. letter.

The Commissioner : Does it compromise the lady to mention it?

Witness : Yes.

The Commissioner: Then we had better say nothing about it.

Witness : Her statement was quite rational about the letter. I saw her the same evening at Dr. Shapter's cottage. The conversation took place at Miss Cousens'. In the evening when I saw her at Dr. Shapter's she was arceedingly polite, pointing out several places in the scenery. She named the places correctly, because I have since learnt such is the case. She showed me Exmontb, the direction of Dartmoor, Starcrose, \&c. Ermonth is some me Exmontb, the direction of Dartmoor, Starcross, \&c. Ermonth is some
distance. She was quite correct; I did not discover any want of comprehension. No conversation on business passed except this :- "What present was I going to take home to my wife," and begged that I would show it to her. I saw her the next day, when general conversation passed, and she begged to be remenbered to all her friends. I communicsted with Mr. Ellacombe, sen., that day, and I told him what had passed. He sent in his account, and I paid it. I saw her in chnrch on the morning of the 17th of April. We walked paid it. I saw her in church on the morning of the 17 th of April. We walked at Warrington. She said that she was very glad that Dr. Greenall was likely to come in again, referring to the election then pending. She said that she had read my speech, and produced the Warrington paper containing it. On the 18th of April I talked to her about her will. Dr. Greenup had been there, and that was one reason of my coming down. I told her she was well enough to make her will, and if 80 she had better make it. She said "I will when I am a little more tranquil, but I will mention it to Dr. Shapter," who was not in Exeter that day. I think nothing else took place.

By the Commissioner: I told her that she had better make her will, as people came hunting after her money.

Examination continued: She said nothing more about her will then. I saw her again on the 21st, 22nd, and 23rd of May. She seemed somewhat alarmed. She had been served with a process in lunacy on the 17 th.

By the Commissioner : She said she knew what I had come about and ahe wished me to defend it. 


\section{$\mathbf{x x}$}

Irramination continued : I came in consequence of her sending me the "paper." She told me to defend it, and signed the notice for this jury. The would not sign it till it was explained. I told her it was a notice that she meant to resist the petition. At first she said she was afraid, I asked Dr. Shapter to explain it, who was present. He told her what I had said, and she then signed it. Nothing else passed, I came away. That was on the Mondey My impes maw gaw her once. I came late on the Saturday night. I was employed about wards at Dr. Shapter's. She told me that Dr. Bucknill had been putting her through her calculations. She said "He asked her to count."

By the Commissioner: I won't swear that it was the exact words that she used, but I think they were.

Fxamination continued : She took out her purse. She said she had been puzzled. She was sitting at the time. She said "He had asked her to count, and said something about the multiplication table." She had been puzzled. She took the money out of her purse and counted it correctly, she said she was ashamed of her shabby purse, I then gave her mine. The purse was shabby, and I believe she was ashamed of it. My purse was a very handsome one. She put her money in her own purse, and folded mine carefully up and put it in her pocket, and raid she would use it when this enquiry was over. I have seen her in company with some eight people at dinner. She conducted herself most rationally and properly. I think it was in April last. She joined in conversation. She spoke of her friends, she starting the subjects, which were principally about Warrington. Her remarks about what other which were principally about Warrington. Her remarks about what other
people said were quite pertinent. I recollected repeating an epigram about a marriage which she laughed at very much. I have known her 40 or 50 years.
I think she is of perfectly sound mind and capable of managing her affairs. I saw her yesterday and she talked rationally.

The witness here offered to repeat the epigram which related to the seige of Sebastopol.

The learned Commissioner intimating that he should like to hear it, the witness repeated the following :-

$$
\begin{aligned}
& \text { What means to-day the mingled rattle, } \\
& \text { Of bells and cannons in our town? } \\
& \text { Is it that Mars, the god of battle, } \\
& \text { Has brought the Russian eagle down ? } \\
& \text { No 1 still hor'ring o'er us, in defiance, } \\
& \text { Mars has not glain the traitor yet ; } \\
& \text { But love and hymen in alliance, } \\
& \text { Have caught a Lion in their net ! }
\end{aligned}
$$

By the Commissioner : I think her quite capable of managing her affairs, and should have no objection to take her instructions to make a will. But $\mathbf{I}$ would say that I have not seen her at any lengthened interview lately. In May, when she had been served with a process, I don't think I should have liked to have taken her instructions.

Examination continued : I received all her letters. I ought to have received a dividend warrant from the London and North-Western Railway. I did not open her letters though. The dividend warrant did not arrive, and I asked if it was among the letters which I had sent her. She brought out her papers, and it was not among them. I afterwards learnt that Mr. Ellacombe had and it was

Cross-examined by Mr. Smith : I searched to see if the letter was there. I believe she said she was not aware that it had not arrived.

By the Commissioner : It had not arrived.

Cross-examination continued : I am the solicitor in opposition. I came on the 21st, a Saturday. I came because she had sent me the paper. She did not send it, but Mr. Campion did. I saw her on the Monday morning. I saw
on the Sunday a gentleman, Mr. Charles Ellacombe, about making an affidavit. I had spoken to Dr. Shapter about steps to be taken to oppose the petition. Directly I received the notice, I commenced steps to have it tried by a jury before I saw her. I think it was begun in London. She said that she knew I was one of the persons who had helped send her to Haydock, and, 


\section{$\mathbf{x x x I}$}

therofore, she asked Dr. Shapter about it I think before signing. I can only explain it by that, though I have been her solicitor so many years. [Mr. Campion's letter was put in and read.] She seemed to be attached to her friends at Warrington, and was not therefore friendless. She had received kindneases from them. Mrs. Lowe was one of them. After the paralytic attack she soemed more melancholy. I did not observe that her memory was any worse or more defective. I know that it was thought desirable that she should be placed in a private place and not in an asylum. I did not visit her in the asylum. I think Bowden was the place mentioned. I believe it is a very healthy and pleasant place. It is a suburb of Manchester. I did not know there were any relatives, but afterwards understood from Mr. Ellacombe that she had relatives in Devonshire. He stayed at my house. My firm is Beamont, Urmson, and Daris. It was agreed that an order should be made for an application in chancery. I think when she went to the banks for money they filled up the cheques and she signed them. I came down to Exeter in consequenoe of Dr. Greenup having been here. I think Dr. Shapter wrote the letter which I reoeived. I having neen here. I think Dr. Shapter wrote the letter which 1 received. I do not think I received a letter fron her for the last twelve years. I told her she was well enough to make her will. I commenced the conversation. I think it is very likely that I might have heard from Dr. Shapter, either by letter or word of mouth, about it. I won't undertake to swear about it. I believe I did not speak to Dr. Shapter about it. I think it very likely that Dr. Shapter, in some of his letters, had alluded to her fitness to make a will. [A letter, dated 12th of March, was here put in and read.] I said on one occasion that she was too much excited to have attested a will. I saw her alone on the 18th of April. [Another letter, of the 7th of May, was here put in and read.] I did forward an acoount of her property to Dr. Shapter. I have never written to her about it. I sent the letter to Dr. Shapter. I did not prepare any document in consequence of the letter of the 12th of March. I have certainly not prepared any documents for her, except the cheque for $£ 500$, which I sent down in blank to Dr. Shapter. It was filled up by me on the 10th of May, and sent on that day. Sho pointed the places to me. In some respects her eye-sight was remarkable.

By the Commissioner : She had "long sight." I have not seen her read except at church.

Re-examined : She had friends at Warrington.

By the Commissioner : Her friends comprised many of the principal people at Warrington.

Re-exqmination resumed : She was greatly displeased with Mrs. Lowe about the asylum. She said Mrs. Lowe had ordered her to be placed in the carriage by force when she was coming to Devonshire. She repeated it again and again that she was displeased with Mrs. Lowe. Mrs. Lowe had nothing to do with taking her to the asylum.

By the Commissioner: I wished her to state the names of the friends to whom she wished to leave her money. She said nothing to me about being made a Roman Catholic. I knew nothing about her delusions except from the affidavits.

The Commissioner: Don't you think that any one sincerely wishing to ascertain the true state of her mind, should have made this enquiry?

Witness : I did not do so.

Mr. John Sharp, surgeon : I live at Warrington, and have attended the Ewings's family for 30 years or more. Miss Ewings's sister died in 1853. I was in the habit of seeing Miss Phoebe Ewings from time to time before her paralytic attack. I do not know whether I attended her professionally. She visited my family. She retired from society much. She seemed to be more desponding. She had peculiarities, but not more than most old maidens or bachelors. (A laugh.) Her general disposition whs generally good. Her conversation was natural but often trivial. This is the character of her mind. Her conversation, however, was natural. From the time of her paralytio stroke her,memory was rather defective, and increased at the time of going to the asylum. I visited her in the asylum four times.

The Commissioner : Mr. Collier admitted that she was at this time.

Examination continued by Mr. Kingdon : On the 8th of February, the last visit, I did not. detect loss of memory, but she said she heard noises in the house. I did not see her again until the 28th of May, at her lodgings, at Mise Cousen's, in Exeter. I put down on a bit of paper notes of the conversation. 


\section{$\operatorname{xxx}$}

The witnees then proceeded to read from his notes which he said he had made the ame day.] Dr. Shapter told me that he wished me to see her. Sho shook me heartily by the hands, said she was very glad to see me; began by referring to the recent troubles in Warrington; she said "You know," but did not add what. I said to her "Come, now, you must not say anything about Haydock, you know you are far removed from there." She then enquired after Mrs. Sharp, my sons, the alterations of the parish church to which she had given some money-asking if any of the vaults there had been disturbed. Her mother and sister had boen buried there in vaults, but not her last sister which the Isw prevented. This disturbed her. She was buried in a vault in St. Paul's Chnrch She thanked me for a newspaper I sent her, containing an account of the laying the foundation stone of the extension of the church, and of Mr. of the laying the foundation stone of the extension of the church, and of Mr.
Greenull's election; asking about her pew in St. Paul's church she used to go Greenall's election; asking about her pew in St. Paul's church she used to go
to. It had been cleaned. She asked if her house had been turned "up side down." I know no more about the pew she mentioned. She asked how her house in Busy-street looked. This was the one she lived in. There were five persons at the dinner table that day besides Miss Ewings and myself. She asked me if I would take a parcel for her to Warrington. She talked chiefly abont the election, and asked what the Radicals did. She was a good Tory. (A laugh.)

Mr. Smith : She has not chosen her counsel.

Mr. Collier : You cannot say not well. I don't think my friend can call it a

proof of her madneas. (Laughter.)

Mr. Smith : Certainly not.

Eramination continued : When I was going away she gave me a parcel and told me what it contained. It contained sea-weed collected by herself and told me what it contained. It contained sea-wreed collected by herself and sister, and desired me to give it to Miss Sharp. When about to leave the table she spoke to Dr. Shapter. All I heard was the "fee." She did not say thought ahe took the greatest amount of talking. which rather interfered with my eating. (A langh.) The presence of an old friend was interesting.

By the Commiscioner : Her conversation was quite rational, and such as she had been in the habit of using when in Warrington. I say the same of it in the evening. I saw her yesterday unorning and evening. In the morning I
was with her about a quarter of an hour. Mr. Cole and Dr. Shapter were with was with her about a quarter of an hour. Mr. Cole and Dr. Shapter were with
her. In the morning she enquired after my health. Mr. Beamont went into the sitting-room first, and I followed him. She was standing on the floor. She was dressed in a walking dress. She said, "I won't go to church this morning." Dr. Shapter advised her to go, but she ssid, "No, I will go this afternoon." Then she made some reference to this "shameful affair."

By the Commissioner : I don't know that those were her words. I said keep your mind easy, all will go on right. She then said something about Dr. Kendrick and Mr. Mould going to the railway, that she met them, and that she supposed they had been "going against me." I said I heard their evidence, and I think it was as inuch for you as against you, if not more. She did not make any reply. Nothing was said about seeing her in the evening. But about six o'olock I was at Dr. Shapter's country house, and Miss Ewings came. I had three-quarter's of an hour's conversation with her. The principal part of the conversation was about her friends in Warrington. She called their nanies except two. One was Mrs. Lowe's daughter, whose name I do not know though I know her personally.

The Commissioner : During the three-quarters of an hour's conversation, did she refer to this enquiry ?

Witness : I believe she did not once make allusion to this enquiry.

Examination continued : Her conversation at that time was quite rational, and the same as before the attack of paralysis. She enquired about Mrs. Lowe who had told them to put her in the carriage. She asked how Mrs. Lowe and her danghter were. I said she had had a paralytio stroke. She said "I am very sorry for her though she behaved very cruelly to me. Her family is subject to palsy." I said I don't remember whether they are. Twice she said she was sorry, and twice that the family of Mrs. Lowe was subject to palsy. I think she is of sound mird, but her memory is still defective. I think decidedly she is capable of managing her property. I should have no objection to attest any will she might exeoute. But I think she should not be exoited. I have said 


\section{SXXIII}

that I think she was quite competent to execute a will. I have said so to

Cross-examined by Mr. Smith : Her conversation was natural, but on trivial subjects. Her memory so far as manner was concerned was failing. In the year 1853 I observed it particularly. She was very much affected by her ister's death. The paralytic attack affected her speech, and one arm. I signed sister's death. The paralytic attack affected her speech, and one arm. I signed the certificate under which she was sent to the asylum, and visited her four times.
I saw her afterwards on the 13th of February. I thought she was unsound, and I am still of opinion that at that time she was unsound. I did not see he again until the 28th of May. After the paralytic stroke and before she went to the asylum I found that she entertained some suspicions about the servants. But I did not know at that time whether there was any foundation for the thought. Mr. Sharp then confirmed a former witness's statement about Miss Ewings wandering in the streets, and especially when she run out of the house. $I$ liked the servant to be present at my professional interviews with her, to see if I liked the servant to be present at my professional interviews with her, to 800 if
she answered right. She "thanked" me for a newspaper which I had sent her.

The Commissioner : I took it to be that she only " thanked" me for it.

By Mr. Smith : I rather avoided any conversation that would excite her. I did about her " delusions." Last night she was quite calin when talking sont her Warrington friends. She was calm, in good spirits, and frequently about her Warrington friends. She was calm, in good spirits, and frequently langhed. Mr. Ireland Blackburn lives about eleven miles from Warrington. I recollect Mr. Isaac Blackburn's family. They have left for a great number of did not live in Warrington. I heard the word "fee." Dr. Shapter nodded his head. She did not give me a "fee." She formerly paid me my amount every year. Mrs. Lowe was always very kind to Miss Ewings, who had a very strong objection to go to the asylum. She sppeared contented to be in Fxeter, and bije that effect yesterday. She is able to manage her property, but of course requires a person to assist her. I can't say whether she is able to correspond.

By the Commissioner : Her sister could continue a conversation for a longer period. Miss $\mathrm{Ph}$ cobe would stop abruptly at times.

The Commissioner : Did you take wine? A. No. Q. Did you see her take wine? A. No.

Cross-examined by Mr. Smith : If she was free from excitement she would be free to execute a will. Assuming that she was told that persons were coming down hunting after her money, I don't think she would be in a fit state to axecute any instrument, especially if she was told that they were coming down in an hour or a short time. If eight or ten people were to go and see her, I don't think she would be excited. A little tended to excite her, especially - strangers being present. I don't think she is in a fit state to be taught any; had I not known her. I only wonder her " mania" has not returned after the examinations she has undergone.

Re-examined by Mr. Collier : I think her memory has failed since her sister's death. She used one person's name for another. I think it arose through a mistake of words. Her mind had not failed 80 far that I should think her of unsound mind. This is up to the time of the paralysis. When I saw her at had the attock of as she was before she had the attack of paralysis. She looked very well, and more like she used to do, she used to be very pretty. Bodils and mental health often go together, but one may fail without the other. She looked better than she had for six years. There is nothing very peculiar in her failing, unore as regards memory, than when not excited. I was in court when Dr. Bucknill gave his evidence. I think the examination of that gentleman did confuse her. When cross-examined by Dr. Bucknill as she was, I should think she would be confused, and should be astonished if she was not. When nervous she would not be fit to make a will. But supposing her excitement to have subsided, and onl l friende to be with her, then I think she would be in a fit state to make a vill. Erach of the times I have seen her, I think she could have made a will. Mr. Collier : Does she know by whom she is surronnded? Witness : Yes, I think 80 .

Bo-eramination resumed : She shook me heartily by the hands. 
Mr. Collier: Does she know what going to ohurch means? A : She waw pretty regular in her attendance.

Mr. Collier: We must assume a good motive. Witness : When she is calm she knows her friends from others, and could call them by name.

By Mr. Collier : She has told me that she has visited the Rostons. She spoke to me about the newspaper, and spoke about the contents. She asked me about the vaults, \&c.

The Commissioner: Did she refer to the contents in such a manner as to lead you to believe that she had read it?

Witness: Oh yes. I think she had said she had read every word.

Wr. Collier: Might it be that when put into her hand she might fail through the examiner doing it?

Witness : I thought so when I heard the evidence. If excited she could scarcely be able to read. She might be able to read, but I have no proof that she can read.

Mr. Smith: I was going to ask that question.

Witness : I oannot say anything about her knowledge of figures. I should gay "certainly not" to the question that every old lady was a lunatio because sho oould not do figures. (A laugh.)

The Commissioner: You have told us this morning the state of mind in which you say you found her yesterday?

Witness : Yes.

The Commissioner: It was your judgment that so far as her powers of management goes, she can manage her affairs?

Witness : Yes.

The Commissioner: Now the question is, and I have written it down for you, supposing Miss Ewing had yesterday taken the life of another person, and you were this morning asked-if she were being tried for her life-whether she was a rational being and accountable for her actions, would you answer that she was of sound mind, or that she was not?

Witness : I should say she was of sound mind when I saw her, but that having had an attack of mania it might suddenly return, and then of course she would be of unsound mind, but if she had done it while talking to me then I will say "while in a sound state of mind," but no medical man can say how suddenly an attack of mania may return after it has once appeared. If my memory serves me right, I might say that on the evening of the day when she ran out of the house in an excited state she was ealm in the morning.

The Commissioner : But supposing no attack of acute mania had supervened -of which we bave spoken - do you think that if she had killed any one it would have been " murder?" Would you now sitting in that chair tell the jury that in such an aspect of the case, you believed that she was of sound mind? Witness : Of sound mind.

The Commissioner : Suppose with your present knowledge-which you have given to the learned counsel and the jury-you were now to be suddenly informed by some one that she had taken away life?

Witness : The answer would be, that a sudden attack of mania might bare set in ; but my impression is that she would not have done it while talking with me, but she might have done it in consequence of a sudden attack of mania having come on.

The Commissioner: Are they very liable to such attaoks of acute mania? The Commissioner : Are they very liable to such attacks of acute mania?
Witness : I can't say peculiarly liable to sudden attacks, but I know they may have it.

The Commissioner : Did you ever hear of the late Dr. Pritchard's work? Witness : Yes.

The Commissioner : Do you consider him a good authority ?

Witness : Yes.

The Commissioner : Do you agree with this - "The diseaso-mental insanity - often appears in a more narked and sudden manner in elderly persons who have sustained a slight attack of apoplexy or paralysis - which has perhaps speedily recovered-and which might be expected to have left traces of the disease. The expectation is verified so far as the sensative and motive powers are con corned, but the seat of intelloot is found to have been shaken at its very centro." 
XXXV

Witness : I don't think my experience will enable me to say.

Charles Nicholls Cole : I was at Dr. Shapter's last evening, about six o'clock, and saw Mitss Ewings. Dr. Shapter and Mr. Sharp were there. I walked up with Mr. Sharp to dine there, and Dr. Shapter afterwards arrived. Miss Ewings arrived afterwards. I was in her company from a quarter past six till a quarter past eight. She was introduced to me. Mr. Sharp spoke to her for about a quarter of a hour, when I left. I conld see that she knew to whom she was conversing. I confirm all Dr. Shapter said about her while I was there. At dinner she sat near me. She appeared reasonable. She did not manifest any want of intellect, and she talked about ordinary matters the same as other people. Speaking about archery she said she could not pull the bow. I spoke about a lady who broke her leg at the Crystal Palace. She said she regretted it, and also she was sorr ther she had never seen the Crystal Palace. She retted it, and also ase was sorry that she had never seen the Crystal Palace.

By the Commissioner : She had a smile upon her countenance when she said it. Perhaps it might have been in a cheerful manner.

Cross-examined by Mr. Karslake : Her manners are ladylike. She did not of course talk to me like she did to Mr. Sharp, because I was a stranger. Our conversation was upon general subjects.

By the Commissioner : I did not attempt to elicit the state of her mind. She seemed very self-possessed. There was no depression about her. She does not look above 60 odd years. She is the most remarkable person I ever saw for 80 years old.

Dr. Thomas Shapter examined by Mr. Collier : I am a physician, of Exeter. I knew the Misses Ewings seven years ago when they were in Exeter. They lodged here some months when they were here. I and my family saw a good deal of them. I was their medical man, or, I should say, the elder sister. There were acts of intimacy. My sister and Mies $P$ hoobe Ewings contracted an intimacy. After they went back to Warrington the elder sister died. During her illness was corresponded with, and after the death mourning was sent. Mly sister occasionally corresponded with Miss Phoebe Ewings. I had the misfortune to lose $m y$ sister last year. I forwarded a letter ten days afterwards to Miss Ewings, which I found addressed to her. I sent a note myself announcing her death. I received a letter in reply, written by Mr. Wood. About Christmas last I received a letter from Mr. Beamont, announcing Miss Ewing's illness, and uaking some enquiries ahout her relations. I forwarded that letter to Mr. Charles Ellacombe, of Alphington. To the best of my recollection I heard nothing of her till the 1 kth of that day, when Mr. Ellacombe called and said he had brought her from Warrington. He gave me a general description of her being in an asylum. Wo Warrington. He gave me a general description of her being in an asylum. We agreed that I should see her

By Mr. Smith : The book I am referring to embraces all patients who risit me. Mr. Smith : I must see it if necessary.

The book was handed in.

The Commissioner : As to everybody else it is strietly confidential, because it is the "general diary."

Examination continued. When I gaw Migs Evings on the 10th, at Miss Cousens, she was rather excited, but she told me in a coherent manner the
history of her troubles. She first spoke about my sister's death, and said she hoped I had received the letter from Mr. Wood, which I had. She conld write, but it was rather the work of time, and labour, and trouble. Immense labour, I may say, and not satisfactory to her afterwards-she doubted her power. Sho immediately recognised me, and asked at once about $m y$ children and family, and seemed very glad to see me. She then proceeded to detail to me what she termed "the sorrow she had gone through." She first told me that she had had great aritation and that sho dintrueted her gervant, becaneo sho thonght her servant agitation, up quietly, that she looked th and she saw there what alarmed her. She said "It was shocking; it alarmed me greatly, and shocked me horribly," "I then," she said, "ran down stairs, going to murder me."

Mr. Collier : Did she tell you then what she saw?

Witneas : No, not at that time. 
The Commissioner: Why? Did you not ask her?

Witness : Because I listened to her tale. She said subsequently that she thought she $8 \mathrm{aw}$ a man there. She then went on to say that she had been very violently used in her own house. She said that she had been very violently held, and.that she had been thrown down by the person who had held her. Then the next day she said eight or ten of her friends met in my house, and they told me next day she said eight or ten of her friends met in my house, and they told me if I staid in my house that injury would come to me, and that Mr. Gilbert
Greenall would be glad to see me (Hiss Ewings) at his house. She said ic I doubt the fact, because I think he was away"-however, I was put into a carriage with a strange woman. I thought it might be important, said Dr. Shapter-but I only ascertained it lately that the person who clasped her around the neck was a one-arm person. She said she was put into the carriage with a strange woman. After we had gone some little distance I discovered that we were going the Aancashire and not the Cheshire road, upon which I became alarmed, and said "You are deceiving me," and she then described how she put her head out of the "You are deceiving me," and she then described how she put her head out of the wrong road. The woman in the carriage first endeavoured to soothe me, and then held me down by force until we came by a turnpike-gate, when another woman got in and assisted in holding me down, I then gave myself up as lost, and was quiet for the rest of the journey. She then proceeded to relate that she was put into the asylum and described to me the staircase, which made an impression upon her. She said she was obliged to attend one or two balls given to the insane patients which was distasteful to her. However, she gaid they behaved very kindly to her and very proper. She then she said they behaved very kindly to her and very proper. She then said that Mr. Nicholson and "Mr. Ellacombe had called to take her out of Filacombe told me that he was the nearest relative, but I knew that he wasn't." Then I was taken to Mrs. Lowe's, who told me (Miss Ewings) that Mr. Bllacombe had told her that he was the nearest relative, and that he, the elde Fllacombe, and all the Fllacombes were to have my property. Jane Warren and Miss Consens ware present at this interview. She then described to me in nearly the I " called out, "Yor a clergman' Lowe standing by and seeing her thrown into the carriage in that way. She said the porter in the carriage was in his shirt, and that it was in a second class carriage she was put. She spoke of $\mathrm{Mr}$. Ellacombe with disrespect and dread. The cause she assigned was that he had been the cause of the violence at the railway station. When Mr. Fllacombe called on me about one o'clock, I told him that she being an old lady it would be better for him to let her stay three or four days. From my conversation with Mr. Ellacumbe he impressed on my mind that she suffered under dementia, but I thought her much as before, except a little agitated. On the 17th she expressed \& strong wish to stay at Yliss Cousens. Her story was coherent. On the evening of the $18 \mathrm{th}$, when I came home, I found there was coherent. On the evening of the 18th, when I came home, I found there Was an urgent message from her. I went and found her much agitated. She said Miss Cousens, but that she had fallen down upon her knees to him, and then he said "She must go to-morrow." She then appesled to me. Jane Warren and Miss Cousens were present at the time. She asked me as a christinn, and as a gentleman, to protect her, and said "May I not apply to the Iord Chancollor" I told hor no person could remoro hor again a proper medical certificate that she was ont of her mind, and that I was not prepared to give such a certificate. I left her much calmed and comforted. The next morning I saw her and told her I had received a letter from $\mathbf{M r}$. Flleoombe, saying he had abandoned the intention of removing her. She again appealed to me as a christian and as a gentleman. They are her torms. If there was any attempt to remove her I was to apply to the Lord Chancellor. In the presence of Mr. Winslow Jones and inyself she repeated the story of being taken to the asylum. Though he was a stranger there was no incongruity, or incoherence, though she might have been agitated. She is perfectly able to converse, and has proved an agreesble friend to me.

The Comnissioner : If $I$ and the jury see her will that make her nervous ? A. : To a certain extent it will, but I have prepared her for the visit, and I think sho is quite willing to come this afternoon and seo you in this court. 


\section{XXXVII}

Witness : I think it is beyond her mind to be asked "calculation questions." If she is not agitated I think her capable of conversing upon all subjects. I answer that without the slightest reservation. It is not remarkable for an old woman of 80 to be easily puzzled. She told me she was 80 on the 18 th of this month. I don't think she looks more than 70. [As a proof of her physical power the witness mentioned several instances, among which was that she had walked to Cowley Bridge about a mile and a-half, and that seeing his children using some "dumb bells" about a month since in his garden she took them up and used them well. Each bell weighed $7 \mathrm{lbs}$.] If there is any relict of paralysis it is that she cannot propel her tongue. It was agreed between myself and Mr. Jones that she should be left quiet for one month. I said I would see Miss Ewings and ask her to pledge herself that during that period she would sign nothing. Mr. Jones attended professionally on the 24th February would sign nothing. Mr. Jones attended professionally on the 24th February on behalf of the next of kin. She then complained of her want of wearing to the 25th. She said she was kept without. On the 28th she repeated the complaint. She was very anxious to go to church on the 2nd Sunday after she was in Exeter. She spoke about the church of St. Lawrence, where she used to go Upon putting a question to her she said. "I recollect the orergyan (t) For he usd to For he merely say the words." It is true that seven years before she had made that complaint. I think it is a remarkable proof of her strength of memory. 1)r. Fox called on me on the 10th of March. It was left entirely to him whether he would see her, and he did. In the presence of Dr. Fox and Mr. EHlacombe I said, in $\mathrm{my}$ opinion, Miss Ewings was quite capable of transacting any and all business. I said to Dr. Fox, and Mr. Ellacombe on the 10th of March that "I thought she was quite capable of signing any document properly explained to her, and that I should have no hesitation in witnessing it. That she could leave her property to whom she liked, but that I was the only man in England who could property to whom she liked, but that I was the only man in England who could not accept it." I furt let him know.

By Mr. Collier: I said I could not accept it in reference to myself and $\mathrm{my}$ position, and not out of any mistrust of her capacities. I know that observ\&tions are made upon reedical men when wills are made in their favour under such circunstances.

The Commissioner: And it is very salutary too, that such observation should be made.

After relating the particulars of an interview between Miss Ewings and Dr. Fox on the 10th of March, Dr. Shapter proceeded to say :-On the 12th of March she desired me to write to Mr. Beamont, authorising him to make me her guardian. She said she wished to have her affairs settled, and that she had never had the care of money. She said she had no relations or none she cared ahout. That her nearest relations were unkind to her and her mother, and that she wished to be protected against them. She hoped I would not let Mr. Ellacombe come to her. She desired some money as she had not given Miss Cousens her Christmas-box. It was her custom to send her a guinea every year, but had omitted it this. I still adhere to the fact that I think her mind is clear, and that she has mind to manage her affairs. IA letter written by Dr. Shapter, in relation to this point, was here put in read, and confirmed by him.] Her wish to make me her guardian did no make me think her unable to manage her own affairs. I certainly do think that it does not indicate an unsound mind for an old lady of 80 to wish a guardian. I think her capable of signing anything she is called upon to do. She is a woman of very remarkable mind. I will defy anyone to make her sign anything which she does not wish to sign. IInstances were given by the witness to support his testimony. Among them was one in which Mr. Beamont asked her to sign a paper relating to the action, but which she declined to do until sign a pape rotang to the wastion, bre which ledge Society, and $£ 45$ towards the restoration of the church of Warrington.] She sigued a cheque for me for $£ 3$. I had advanced her the money. She She signed a cheque for me for 230 . I had advanced her the money. She
asked if she could sign the drafts, but I told her her money was her own. She said this because of the pending action. She said she had a right to give her own, went into a back room, sat down, adjusted her spectacles, and read the 


\section{XXXVIII}

cheques. [The witness detailed at length the many enquiries she made respecting the cheques, \&c., to indicate her soundness of mind.] She said cheque for me for $\mathbf{\$ 3 0}$. She had no difficulty in doing 80 . She told me that her clothes had arrived. She showed me a printed report of the Warrington Iadies' Society, and rave me description of the persons. Her own namo was Ladies Society, and gave mo a description of the perahs. Her own name was down, which "I saw his heels." (A laugh.) She also added something else not complimentary to him.

By Mr. Smith : These notes were made at different times. One note was made on the 28th of March, and there was a little addition about a month ago. In looking over my notes I made some addition.

Witness: She wished me to open her letters. She received a letter from a lady on the 4th of April-say from a Miss G. She read it and did not very well like it. She said it was stuff and nonsense. She made a running conment npon every paragraph read.

The Commissioner : One lady commenting upon another. (Laughter.)

Witness : It was a most accurate description of the letier. Her remarks Fere so just that I made the remark. Having deposed to a call of Dr. Greenup, Dr. Shapter said "When he came I thought he came to see her, because he was the next of kin." It was only after a good deal of persuasion that she consented to see him. Afterwards she said she would make her will and leave her money to whom she liked. She was only sorry that she had not done it before, but she always disliked business. She said, "I particularly wish that Mr. Ellacombe and Dr. Greenup-who, when she saw them, she received in a very reserved manner-shall not have my property, beoause the Greenups have I don't recollect the name-who fought the battle for us, and they had to pay all the costs." The next day she again resumed the subject of her will. She wished to have the particulars of her property, and I was to write to Mr. Beamont about it. She remarked what an injury it had been to her not making her will, and said she had nearly done it four years before. A reply was received from $\mathbf{M r}$. Beamont, and I communicated it to her, when she said $I$ thought it was rather a little under $£ 14,000$. I made a copy on a piece of paper. I did not give her Mr. Beamont's letter. She went through the items, and at length said "There are $£ 200$ in the Savings' Bank. [Evidence was then put in to show that this was perfectly right. It appeared that each of the sisters had $£ 199$ in that this was perfectly right. It appeared that each of the sisters had $£ 199$ in the Savings' Bank.] She said "My bankers at Warrington give me two per
cent., but my lady friends tell me that it is too little." [A letter dated the 11 th of May, and written by Dr. Shapter to Mr. Beamont, was then put in and read. ] - $\mathbf{A}$ long conversation here ensued respecting the regulations of a will, but it possessed no public interest, except to show that Miss Ewings exercised her reasoning faculties in giving certain directions respecting a few gratuities to ten poor old women.-Witness : She perfectly comprehended what he was about. The gifts to the ten poor women of $2 \mathrm{~s}$. a piece were to be immediate. She knew the difference between an immediate gift and a bequest. She said I should like to give away geveral things, but I nust not make She said I should like to give away several things, but I nust not make myself too poor. After a few more questions upon this point the evidence
went on to Dr. Shapter's dealings with Dr. Bucknill. I showed to Dr. Bucknill the letter I wrote to Mr. Beamont, saying that I would not take any bequest. Dr. Bucknill made a couple of comments. When he came to that passage which says "I should repudiate anything left me, he said "Yes, that is all very right." On the 30th of May I again visited her, and she said she wished her will to be made out of hand; I gave her the paper and proposed to send for Mr. Beamont. She said, "but you can do it, can't you." I said to send for Mr. Beamont. She said, "but you can do it, can't you." I said yes. I then read over the legacies and asked if they were the right sums,
and she said they were. She then said I wish you to be executor and and she said they were. She then said I wish you to be executor and residuary legatee. I told her I did not wish to have her property. She remonstrated, and said she had a right to give it where she like. I then said I
would send her instructions to Mr. Beamont. She said, "I wish to have it done now." I then proposed that Mr. Gray, an attorney of Exeter, should be sent for. She asked me who Mr. Gray was, and said he was Mr. Beamont's agent, and was acting in Exoter on her behalf. I also said he was the gentloman 
Tho had drawn up Mr. Sharp's affidarit, and whom sho had moen on Saturday. She said she did not know and had no confidence in lawyers. She had no confidence except in me. I told her there must be two witnesses; and ghe sajd she should like old Mary, the servant, and Miss Georgina. I told her there was a difficulty, as Miss Georgina Cousens had a legacy. She said, "Pay her at once." I rang the bell for Miss Cousens, and desired her to go for Mary, saying it was to witness Miss Ewings's will. I added at the top of the paper,

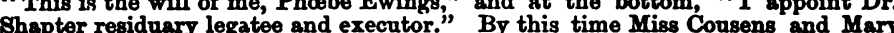
were in the room. I then explained to Miss Cousens that her witnessing the will would invalidate her legacy; that I had mentioned this to Miss Ewings, who had would invalidate her legacy ; that I had mentioned this to Miss Ewings, who had Ewings, who at this moment had the pen in her hand, and was sitting at the table rose from her seat, walked up to Miss Cousens and saia, "You and your sister can have your legacies directly," and then turned to me and said, "Iet them have their money at once." "She next turned to old Mary and said "Reoollect there is no legacy for you." She resumed her seat and signed her name in the best signature I ever saw her make. The two witnesses signed. I then explained to Miss Ewings before them what she had done, that her money , done, that her mone or do what she liked with it, and that when Mr. Beamont came he must read or do what she liked with it, and that when Mr. Beamont came he must read full account of the transaction to Mr. Beamont. I also showed it to Mr. Gras, who attended on Miss Ewings and made another will. She then said, taking the original instructions, "People are very curious," and then tore the paper to pieces. On the 2nd of July the second will was made, myself, Mr. Gray, and Miss Cousens being present. Miss Ewings would insist on $\mathrm{m}^{\mathrm{y}}$ remaining, and she executed the will. Immediately afterwards I wrote to $\mathbf{M r}$ remaing, and she een her before and after Dr. Bucknill's visits; and I noticed that she was then very nervous and dreaded them excessively. On the day after that she wast then very nervous and dreaded them excessively. On the day after Dr. Bucknill's fourth visit she was dreadfully agitated, and her mind was so
disturbed that she could not say a word. She said she had been disturbed during disturbed that she could not say a word. She said she had been disturbed during the whole of the night with figures. The night succeeding my interview was a sleepless one, and she was much agitated on the following morning. I agree culating powers. Her politeness would often induce her to conceal a great deal that annoyed her. On one occasion Dr. Bucknill cross-examined her in my garden, and she fell back against the rails exhausted, saying, "I can stand it garden, and she fell back against the rails exhausted, saying, "I can stand no longer, and I remonstrated with Dr. Bucknill. I think Dr. Bucknill at visits would confuse her mind altogether. On the second visit of Dr. Bucknill a my garden she was very cheerful and lady-like; and it was quite impossible for the most imaginative man to find out that she was insane. She is a littlo looking so well now as she did a month ago; but $I$ am surprised that she bears it so well, as she understands the nature of all these proceedings. Undoubtedly she is in sound mind. I have never seen anything during the six months she in to to uch quickness of perception You address a question to her, and you fancy she does not hear it. You address it a second time, and then she is herself again, and will enter into conversation. That is not uncommon in persons of her age. She has most remarkable memory; much better than 1 have. She will, however, at times make use of wrong words. She has a little difficulty with regard to getting out the right name. If she were speaking to you (Mr. Collier) for ten minutes she might turn round and address me as Mr. Collier. This is s mistake of words, and not a confusion of ideas. I attribute it to the creeping on of old age, and to the paralytic attack, which has given that peculiar qualit to her mind of making use of wrong words. That habit constantly recurs in persons who have had paralytic attacks. My opinion has not been altered by persons who have had paraly

Mr. Collier : Have you made the slightest concealment of anything

Mr. Collier : Have you made the slightest concealment of anything? gentlemen. I believe all who came except Mr. Roberts. On the 28th of May, ahe was told that it was thought there would be an end of the petition, and ahe 
then asked if she were to make a will if it would bo disputed? I gaid, "I don't think that any will which you were to make could be successfully disputed." Dr. Shapter, in ooncluding his evidenoe, stated that Miss Ewings in giving instructions about her will wished to make-him residuary legatee. Though he had never heard her use the word before. She said, Is it right? "I told her I really did not wish to have her property."

The court here adjourned from five o'clock until seven.

Dr. Shapter was then cross-examined by Mr. Smith : He said,-I had not seen Miss Phoobe Ewings from 1852 until she came to Exeter lately. My sister cen esponded with her. I think she must have written within the last twelve months. My impression is that she had paralysis which affected her tongue. I months. My impression is that she had parad ysis which affected her tongue. I decay of old age. I am not convinced that she has had any attack of mania. I have very great doubt about it, and I still doubt it.

Mr. Smith : When she was put into the Lunatio Asylum do you think she was unsound? Witness : I think she had a severe attack of delirium.

By the Commissioner: I mean that disturbance of the mind that she had no control over herself.

By the Commissioner : Do you not call that insanity ?-Witness : You may call it passing insanity.

By the Commissioner: Do you think the medical gentlemen who signed the certificate wrong ?-Witness : I question the delusion. There was an exaggerated feeling about her. She might exaggerate very much what took place, but I think there was very good grounds for her belief. She told me that a woman of one arm had thrown it around her neck.

Mr. Smith : Do you believe what such patients tell you ?-Witness : I hare since ascertained such to be the fact. I do not think she has been subject to any delusions except sane hallucinations. There might not have been a man in the room when she said there was.

Mr. Smith : What is the difference between delusions and halncinations?Witness : She might have seen a shadow, and have become alarmed.

Witness: When she went into the street, I think there was an exaggerated foeling from that hallucination.

The Commissioner : You do not think she was under any delusion?

Witness : I do not think she was, but at any rate she had an exaggerated

impression. Taking her to the asylum might have made her mind more feeble.

The Commissioner : Do you think when she was removed that she was suffering from unsound mind?

Witness : I think she was suffering from delusion.

The Commissioner: Was she rightly taken to the asylum as a person of ansound mind?

Witness : I doubt the policy of it.

A variety of similar questions by Mr. Smith were then put to some of which the witness said : I do not surrender my opinion to that of others, who have seen her before she went into the asylum, and when she came out. It is very difficult to define the difference between delusions and manis. I should be very sorry to do it. Delirium is more a passing irritation of the brain, while manis depends more upon disense of the brain, and is more likely to be permanent. Delirium would be likely to pass off with the source of irritation. I have known persons suffer under delirium more than two months.

Mr. Smith : They would be in a state of bodily ferer at the same time? Witness : Yes.

Mr. Smith : Have you heard of any bodily fever in her case? Witness : I have not heard of any delirium while she was in the asylum. I have not heard in evidence of her being in a feverish state.

Cross-examination continued: Delirium might pass off with the exciting cause. I discussed with Mr. Ellacombe the propriety of suitable lodgings for Miss Ewings near Mr. Ellacombe's house. I think I advised it, at least I knew about it. She communicated her dislike about Mr. Ellacombe the first time I saw her. He had been the means of bringing her out of the asylnm. She said Mr. Fllacombe had forced her into the railway carriage, and that she doubted
his intentions. I tried to remove her doubts, and have never spoke deshis intentions. I tried to remove her doubts, and have never spoke desplacing her in the asylum. She could not believe that ho had a good notive 
In bringing her to Devonshire. She had a grudge againat Mr. Beamont for putting her in the asylum. Though he is her solicitor now, she still "refleota" patting her in

Mr. Smith : She has confidence in him as a solicitor, but thinks him wrong in putting her into the asylum.

Witness : Precisely so. I think she has entire oonfidence in Mr. Beamont, and still thinks him as a friend, but thinks of the "indignity" put upon her in thrusting her into the railway carriage. I think she was treated there with great indionity. I told her generally that I thought Mr. Ellacombe intended to oot kindly towards her. " Her conversations are very agreeable and not to act kindly towards her. Her conversations are very agreeable and not
trivial. [The witness was pressed upon this point by the Commissioner, but trivial. [The witness was pressed upon this point by the Commissioner, but I differ from Mr. Sharp if he aaid so. I withdraw my words if I said she conld converse rationally on "all" exbjects. That is too comprehensive. I think she had a good education. I had authority from Miss Ewings to refuse permiscion to persons calling themselves "next of kin." (A laugh.) She said she had no "Oelations, and that her nearest relations had been unkind to her. I did not eas "Oh! It is a family quarrel, it will be good feeling to make it up." I I did ter in. Fox and Mr. Elacombe on the 10 th of Maroh, "That I was the only man in Fngland who could not receive her money. The ides arose in my mind that she intended to leave me something, and I knew my position was verY
peculiar. She was a person of remarkable memory. I told Mr. Fllacombe that I wonld let him know before she signed any document; that was on the 16th to March.

Mr. Smith : And afterwards you spoke of getting the powers to enable her to make you the protector of her property. What position did you expect to occupy? Witness : I thought she wished me to manage her pecuniary arrangements.

Mr. Smith : You might have done that without being formerly constituted the protector of her property. Mr. Smith read the letter by Dr. Shapter, atating that he was desired to apply for the power. Witness : I thought I should take the charge of her, that nobody else should interfere. I told Mr. Ellacombe I thought he was not the next of kin.

By the Commissioner : I think Mr. Ellacombe was rather a "connection." Witnees : I think no man would make her sign a document if she did not wigh to do it. I do not say she could understand anything. As a general rule sho had a great dislike to transact business. She would not sign the notice for the jury till it was explained. She signed a cheque as I have said, and one for me for $£ 30$ for money advanced.

By the Commissioner: I have not nsed the draft. The date was the J6th of May.

Cross-examination continued : I think she had a perfoct right to do as sho liked with her money. I did not prefer cashing this cheque. All communication with her was by me. The 5 th of April was the first day mention was made about her will. I don't think she was in a state of excitement. I gave her the particulars about her will, the day after I had received them. She first mentioned her intention of giving me a legacy on the 11th of May. She merely said she wanted to give me a legacy, I explained to her the position I was in, and that I should not accept the legacy. She said "Their must be some thousands left and I ahould wish yor to have them."

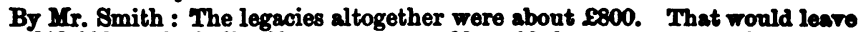
about $£ 13,000$, or the bulls of her property. She said these persons are all wealthy people, and my property is nothing to theirs, I only want to give them something by which to recollect me.

Cross-examination resumed : She still wishes me to be the residuary legatee. She clearly understands now that I am. Mary and Miss Cousens attested the will. She had given Mary $\& 10$ a short time before. The will was entirely in my handwriting. I did not tell Mr. Enacombe that she was going to make a will nor Dr. Greenup. I did tell Mr. Holland. I said, in a letter, "I mean to repudiate all benefit myself."

Mr. Smith : Had you sufficient influence to prevent its being done?-Witnesp: It was not done with any premeditation. I thought that anything she wishe to do under present circumstances ought to be done. 
M. Smith : Why? You would not take the oheque money "under existing circumstances ?" Witness : No, but I used a great desl of infinence.

Mr. Smith : Could you have prevented it if you like? Witness : I think might, but it would have placed me in a difficult position; I rather wished to avoid it if she asked me what she must do with the money. I never influenced Miss Ewings in any one respect.

Mr. Smith : Did you use your influence to counteract it? Witness : I did nse a fair amount of influence.

The Commissioner: You said just now, that you never influenced her at

all, and now you say you used a great deal of influence. Is that consistent?

Mr. Smith: Did you not say you used a great deal of influence in order to get her to sign a paper, which Mr. Beamont couldn't? Witness : I explained the paper, and 80 far used that influence.

Mr. Smith : And should have undoubtedly have repudiated it if done? Witness : She believes I am now residuary legatee.

Mr. Smith: You said you never disguised anything from her? Witness : Yes, I did.

Mr. Smith : This is a pretty considerable disguise, is it not? Witness :

Yes, it is.

Mr. Smith : Do you think it is a strange thing to make you the depository of $\$ 13,000$ ? Witness : I should have repudiated it.

Mr. Smith : Did you intend for the "next of kin to have it?" Witness : I took it that the "next of kin" would have had it.

The Commissioner : You intended that the repudiation should comprise not

only yourself, but all members of your family? Witness : Most unquestionably. Mr. Smith : Did you suppose that it would ultimately have come to the

next of kin? Witness: I did not suppose anything about it.

Crosa-examination continued: If that will had come into operation tomorrow I should have paid the legacies, and the other money to the next of kin. That has been my expressed opinion.

Mr. Smith : Then you would have done this, and yet did you ever treat a sane person that way before? Witness: (After a long panse,) did not reply.

Mr. Smith : I suppose not? Witness : I did not know that you were waiting for an answer. (Oh!)

The Commissioner: Did you ever treat a sane person in that way ? Witness No, certainly not.

The Commissioner : This is a solemn question. Did you believe her sane at the time? Witness : Yes, and I think so still. I think she has a perfect right to leave her money to whom she pleases.

The Commissioner : Supposing you had died the instant after she had, would not your executors have had the property? Witness: It did not flash across $\mathrm{my}$ mind. I rather thought I should repudiate it, and not take the money.

Mr. Smith : Then this will was made by this old lady because Dr. Greenup came and annoyed her, and then you take the property with an intention of repudiating it. Witness : I believe so. That is the case. Persons were not allowed to see her by my sanction at her request. I don't think that I should prefer seein her by my sanction at her request. I don't think $\$ 10$ she gave to prefer seeing a patient alone in such circumstances. The $\$ 10 \mathrm{she}$ gave to Mary was included in the e30. I think it is understood that Mr. Beamont town. She had not made any agreement with Miss Cousens, because she desired that I would. There are additions to my notes. I have never received any fees whatever myself.

Re-examined by Mr. Coleridge : If I remembered anything afterwards I added it to my notes. The cheque for the $£ 30$ settled my account. I have never treated any one before in a similar manner, because I was never placed in a similar situation. I mentioned to several persons that $I$ intended to repudiate this money. I formed in my own mind a definite notion of what I intended doing with the money. Supposing the will should have come into operation I questioned in my own mind whether I should give it to charities, and I then came to the conclusion that I must repudiate it, because if I could give it to charities I conld put it in my own pocket. Whether it was to go to charitie or to Dr. Greenup I had nover thought. I distressed Miss Ewings if I expressed a wish not to benefit. 
Mr. Coleridge : Was that the inducement to let it be dono? Witnem : . elief.

Mr. Coleridge : Since the will was made in its present shape these procoedings have been taken? Witness : They have.

Mr. Coleridge: Therefore you have had no opportunity of bringing to her mind the effect of the present will? Witness : That is precisely the position of the case. She had told me that she had no near relatives. She is disinclined to transaot business. Assuming Dr. Sharp's account to be true, I should say abe was labouring under delirium, and that it was passing off. The common sanse of mani is that it is a disesse of the brain itself. I should say there come phrical canos for delirinm, and that it subeided as it paceod of: disturbed rather than a diseased mind. My notions of delusion aro " $\mathrm{falso}$ conclusions "- belief in something which does not exist.

Mr. Coleridge : May a person in an excited state have impressions made upon their mind greatly exaggerated and yet not a foundation for it? Witness : Yes, undoubtedly.

Mr. Coleridge: That is different from a delusion, is it not? Witness : Yes Mr. Coleridge: Is that belief in continuing to entertain an exagrerated mpression of a past fact perfectly consistent with a person being sound in mind? Witness : I think it is.

Mr. Gray, solicitor, of Exeter, said, I am Treasurer of the Lunatic Asylum. I have, therefore, seen many lunatics. I attend a weekly board. I hare met Miss Evings within the last two or three months. I met her at Dr. Shapter's. I had an opportunity of judging of her manners. She joined in general conversation rationally and there was nothing in her manner to indnce me to think she was anything different from other persons. I met her on the 28th of May acain. I met her st dinner. After confirming much of former witnesses' evidenco the witness went on to say that he had been employed in making the will. Dr. Shapter told me that Miss Ewings would be glad for me to make a will, and in consequence I went to that lady. Dr. Shapter had furnished me with a list of the legacies. I told him that I should like to nee her alone. I went into the back parlour, and she shook hands. I thought from her manner that she expected me. I gaid, I understand from Dr. Shapter that you have a wish to make youx will. She answered in the affirmative. I read every name with every amount, and she nodded assent to it. I ascertained that she fully understood the matter. I said have you any other legacies toleave? She said "No." I then said to whom do you propose to leave the residue of your property? She said "to my dear, hind do you propose to leave the residue of your property? She said "to my dear, kind roon, but she would not permit him. She took hold of his hand and said she roond, but she would not permit him. She took hold of his hand and said she
rished him to remain. She said I don't wish to leave anything to any relatives. Tished him to remain. She said I don't wish to leare anything to any relatives. time, to whom then wonld you leave your property \%" After some consideration she said, "That can't be, I sm too old." I said it is an event which might hepen" She replied, "True, life is uncertain." She then said, "I wonld the rish my propert to "o to Magter Tom and the ret of the ohildren" I aeid do you mean Dr. Shapter's children? She said, "Yes." In what sharea ? She replied in equal shares.

By the Commisuioner : Dr. Shapter was present all the time.

Witness: When she said she would leave the residue to him, he said "Pray, don't do it," but she said you must, you must have it. She said "I wish Master Tom to have the larger portion." I Baid "What proportion ?" and after a time she said, "I think I shall give him the whole." Dr. Shapter did not make any remark. "But suppose he dies in your lifetime "" "Then the other children can have it?" " Equally ?" "Yes." I then went into another room and prepared a will in accordance with those instructions. She said "Dr. Shapter propar " "I ahall "ant a second ritnees" Dr. Shapter (D). Shapter said "Wn't except she has a legacy of 19 grineas, which will invalidato it. Ho then said "Perhaps Miss Ewings will permit her name being left out of the will, and will give it to her in her lifetime." She assented. She and Dr. Shapter were standing side by side. The will was excouted by Miss Bvings in the usual way. Dr. Bhapter handed up to her 
thin," holding it in her hands. I gaid "You can destroy it," and she did toar it up in vers small pieces. She said "I will tear it up, because no one shall see the contents." Dr. Shapter did not make any remarks. I then left. I did not take charge of the will. During all these proceedings I considered her in a not take charge of the will. During all these proceedings 1 considered her in a very sound mental sat evening in a cab and shook hands with her, though I did not gpeak I saw her last evening in a cab and shook hands with her, though I did not speak to her. She appeared to exercise an independent judgment in the matter. not hare allowed her to do so. It was evident that she was pleased when it was finished.

Cross-examined by Mr. Karslake : I left the will upon the table. 'Dr. Shapter was there, and was the executor. I left Miss Ewings and Dr. Shapter. Mo offices, which are in Queen-street, are about three-quarters of a mile from Miss Ewings'. I took paper with me. I went to the house in Dr. Shapter's carriage. He was with her when she appeared. I waited about two minutes. carriage. He was with her when she appeared. I waited about two minutes. She soemed prepared for the interview. When she said, "Dr. Shapter, my dear friend, I leave the residue to you," she burst into tears. I had seen her twice in witness was then questioned as to the affidavits which he said were sworn to before him, on this occasion, he being a Commissioner. I do not come here as a ccientific man. I am the treasurer of the asylum. I made no draft of the will. $\Delta$ dieverion sprung up respecting the original, but the Learned Commissioner said he thought there respecting the original,

Cross-examination continued: There is a legacy given to a gentleman named Ellicombe, that is Mr. Charles Ellicombe. Master Tom is about 15 years old. It was to go to Dr. Shapter first, then Master Tom, and then to all the other children equally. Dr. Shapter made no objection to that. I left Dr. Shapter in the room, and found him there when I came back from making the will.

Ro-examined by Mr. Coleridge : There was a list of legacies. There might have been relatives in the list.

The court here adjourned, it being nearly eleven o'elock.

$$
\text { TUESDAY.-FOURTH DAY. }
$$

The cont opened this morning at ten o'clock.

Eather Georgians Cousens : I keep a lodging-house in St. Sidwell's ; I have known Miss Ewings for 15 or 16 years; she and her sister have stayed at my house two or three times, remaining two years on each occasion. Miss Ewing was brought to my house on the 15th February, by a gentleman and two females it was about nine o'clock in the evening; she recognised me, and appeared delighted to see me; she recognised my servant, who saw her first; she has been tajing at my honge shince I have seen her almost evury hour; I consider ber perfoctly moundin mind, ir mor sor percolly som hin in min

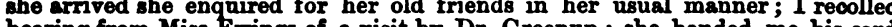
hearing from Miss wings of a visit by Dr. Greenup ; she handed me his card and said, "Another of my so-called relatives have come to see me, but I received him very coldly." She said, "I know nothing more about him than you ; I don"t know that I have ever seen him before; I think I recollect one or two of them coming to my house in Warrington; I think it must be seven years ago." She added, "I suppose he is another after my money." Dr. Shapter was there almost constantly ; I was generally present. I was there when Pr. Fox came ; I recollect a gentleman coming with a paper (the process). When we were walking in Exeter, some daps afterwards, Miss Ewings saw the name of "Campion," and in Exeter, some days afterwards, Miss Lwings saw the name of "Campion," and quite capable of shopping; she is very exact about it ; if $I$ ever paid for anything she always manifested care to repay me again. This has often happened; she bought a shawl and a bonnet; she attends church regularly, and seems to under stand the service as well as any one; she turns over the pages of the prayerbook; she has once taken the sacrament; she was disturbed in consequence of "those wicked people," particularly Mr. Ellacombe, and did not, therefore, take the sacrament oftener; I have slept in the same room with her, and there has

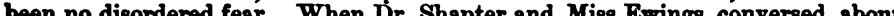
her property, I never listened-I always avoided that topic of conversation with her. On the occerion of the signing of the will, Miss Ewings said she wished to

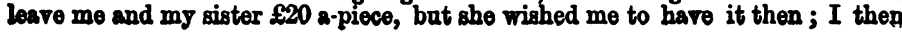


signed the paper; sometime afterwards I signed another paper; Dr. Shapter, Mr. Gray, and Miss Ewings were there; I saw Miss Ewings aign the paper, and $f$ then signed it. When Mr. Gray had left, she said, "I am glad I have done what I have." Two or three days after she said, "You can ask Dr. Shapter for the E20-7ou might as well have it now." She then said, "I should like to make it 250 , and this I will tell Dr. Shapter-I mean between you and your sister."

Cross-examined by Mr. Smith : She was never left alone.

The Counmissioner : Why was she never left alone?-Witness : When I say

" never," I mean generaily, but she used to prefer some one being with her.

Cross-examination continued : I did not hear what passed between Miss Ewings and Dr. Shapter; I have not been in the habit of sitting with my lodgers like I have with Miss Ewings ; she never told me that she oleared up the "mystery" about Jane Warren; she used the words "so-oalled relatives."

By the Commissioner: I never told Dr. Shapter that she used these words. Cross-examination resumed : Friends visited Miss Bwings; there were Mrs. Smith and Miss Chamberlain ; after Jane Warren left Dr. Shapter did not give me directions not to admit any one without his consent; when she was absent me constantly wrote to me; I have never seen her writing letters during the she constantly wrote to me; I have never seen her writing letters during the with letter writing ;" she never went shopping alone.

By the Commissioner: I never recollect Dr. Shapter requesting me to go with her; she appeared much pleased with the visits of Dr. Bucknill so far as I saw ; this continued for a little time, and then she got distressed again as with other people.

Cross-examination continued : I told Mr. Beamont that she would not be left mnch alone; I believe Dr. Shapter knew that I rent out with her; some shawls were sent to the house for her to select from; the bonnet was bought in July; she bought a small neckerchief and a few trifling things.

By the Commissioner : A little binding. for a dress; she never went out for a walk alone; she asked me to go with her; I bought a few trifling things for her when she first came ; no arrangements have been made for her lodgings, nor has anything been paid; Dr. Shapter and Mr. Beamont have spoken about it; the two sisters when they were here paid $£ 1$ 1s. per week for their lodgings; one paid one week, and the other the next; before Jane Warren left Miss Ewings said "Are you paid ?" I said "Do not trouble about that ;" when she said "Wo are staying here like paupers." At a conversation between Miss Ewings and Mr. Beamont, she said, "You will provide all for me, and I wish you to be paid ;" I did not come to any terms.

By the Commissioner : She frequently made allusion to the death of her sister.

Cross-examination continued : She spoke of being at the asylum; the said her servant had behaved badly, but that she wished to say nothing about it.

By Mr. Smith : I cant't say whether she ever spoke of Mr. Filacombe in Dr. Shapter's presence as " that wicked man ;" she might have done 80 many times; she never called Miss Pengelley, Miss Ellacombe, in my presence; she frequently said "I feel I am safe now ;" she always appeared pleased after the visit of Dr. about it.

Re-examined by Mr. Coleridge: I have never been requested "to keep a watch over her; she chose the first shawl at $£ 1$ 1s., which was returned, and likewise a second at $£ 1$ 12s.; whon I gave her the change, 9s, che connted it over ; she looked at the receipt and put it away 3 when M. Fllacombe called and told her she must lesve she, was in great grief and cried mnch; I do not consider that he spoke kindly to her, and it was not till Dr. Shapter came that she was comforted.

By the Commissioner: I brealfasted with her this morning; she did not eat quite as much as usual; she got up at seven o'clock; last night she asked me how it was going on, and said she hoped it would soon be over. This morning she grieved very much, and cried a good deal; she said how she had been treated ; she said "I suppose there will never be any rest for ne again."

By the Comuissioner : I told her last night that Dr. Sinapter had been examined. She said "I am sure he will do anything for me as a friend." She spoke about "the wicked man." Last night when she went to bed she said "Ah! ah! how bad ho (Mr. Elloombo) has treated mo;" or "Ah I how 
bedly. ho has been." She never said anjthing about boing made a ward under the Iord Chancellor. She never said anything to me about being made a Papiat or a Roman Catholio.

By the Commissioner: On my solemn osth I never heard her say so. The Commissioner: "I ask you again solemnly"-(A long pause.) Witness : No, sir, I do not recollect it.

The Commissioner: On your oath, did you not notice an alteration in her when she came? Witness : No, sir; she was looking reak, and said she had boen very poorly.

A letter written by Miss Ewings in June, last year, was here produced by the vitness, read by Mr. Coleridge, and handed to the jury. There was nothing in the contents indicating insanity in the writer.

Mary Ann Rattenbury : I have been a servant with Miss Cousens for 25 Jears; I see no difference in Miss Ewings now from when I saw her before, except in the want of memory as to dates, names, \&c.

Mr. Charles Richard Filicombe : I live at Alphington, on the Dawlish road. I have known Miss Ewings from 20 to 30 years. I have soen her from time to time. I sm nephew of the Rev. Mr. Ellaoombe. We spell our names differently. time. I am nephew of the Rev. Mr. Kilaoombe. We spell our names differently. 1853, written by Miss Phobe Ewings, upon the death of her sister, was here put in.] I received other letters, but cannot say when I had the last. I have not pot the reports of Mr. Sharp. I recollect Miss Ewings came here in Februar last. My unale first informed mo of it by letter. About ten days afterwards called. She saw me. I found her much better than I expected. She received me very kindly. She enquired about my mother, and hoped she was better, and also about my sister. My mother had been poorly. I saw nothing about her which indicated unsoundness of mind. Several other matters were disenssed. I have seen her four or five times altogether. On the 18th of May I spoks to her have seen her four or five times altogether. On the 18th of May I spolre to her there shortly for a walk. She asked if I was going to Scotland this year, there shortly for a walk. She abked if I was going to Scotland this year,
knowing that I had been in the habit of going there. I should think that her memory was good. She spoke and conducted herself most rationally. I was treated in the same way as any other person would treat me. I believe her to be a person of sound mind.

The letter of the 2 nd December, 1853, was put in. It was written in a very pious and affecting manner, alluding to her sister's death.

The Commissioner said he thought it was written with singular propriety,

and certainly did not evince anything but the most proper feelings.

Mr. Coleridge : It shows her to be an educated person.

Mr. Smith : It was written in 1853 .

The Commissioner: Of course, but it is exceedingly well written. I do not believe that a single person in this court could write with greater propriets and feeling.

Cross-examined by Mr. Smith : Dr. Shapter told him that he could soe her when he liked.

By the Commirsioner : She did not speak upon her "troubles."

By Mr. Smith : I was not desired not to say anything upon that subjeot

B. Mr. Smith : I was not desired not to say anything upon that subject. Maria Hanley: I am a servant to the mother of the last witness; a fow
weeks since, in June, I think, I took her some flowers from my mistress; she went her kind love to Mrrs. Fllicombe and was much obliged; she said as soon as he was well enough she would call; but lately she had been so "worried" that whe had not been able to do so.

Mr. George Carter : I am an optician of Exeter, and on the 20th of May last I took some spectacles to Miss Cousens, and saw Miss Ewings; I showed them to her; she looked at several, and at last she found one that seemed to suit her; she shewed me a pair she had purchased from me some time since ; I found that she had ohosen a pair of medium power, and opening a praver book she read that she had ohosen a pair of medium power, and opening a prayer book she read been speaking, she said she could read it remarkably well. She added that she could not see objects on the table better with the new than with the old spectacles; I explained that they were for " near sight." She afterwards spote of persons whom she had seen in my shop. She also asked after my sister; I did not know that she was aware I hills abtor; she then enquired the price of the apeotaclos ; I said two guinoas; she said the prive is not much more than for the 
black ones ; she put down two sovereigns, which I took up: I pansed while she searched in her pooket for 23 . She seemed to make a calculation on the marrin of her purse, and then dropped the shillings back again ; she put the 2s. into her purse, and

The Commissioner: This is much too moving an incident not to be put down. Witness : She enquired for a case, and desired me to go home and get one. I did so, and brought some to Miss Cousens, and told her to present my compliments to Miss Ewings, and tell her that I had to receive 2s., the prioe of the spectacles being two guineas. As I spoke these words, Miss Ewings appeared and said "I am entitled to these 2s. for discount, and if you don't like to lot me have them for the two sovereigns I will have the cheaper pair. I will have the pair of "blacks, which were 18s." That shut me up. (A lavgh.) I let her have the spectacles and case for the $£ 2$. I thought her the "shrewdest" woman I ever knew. (Lond langhter.)

Mrs. Mayne : My daughter carries on business in High-street, as a milliner; I assist her in her business; on the 15th of last month ' lady came to the shop, my daughter showed her some bonnets, and she chose one : she said I am afraid you have not one to fit me, they are worn so small. (A laugh.) They are wrorn small. (Another laugh.) She wanted one made larger, and chose one for that purpose. She said it was more becoming for the bo chose " manve."

The Commissioner: I have not the slightest idea of what it is. (Mnoh langhter.)

Witness : It was most decidedly a good colour for an old lady. The bonnet was trimmed and sent home, and she said if she was pleased with it she would call and pay for it. In the morning she did call, and said itfitted her exactly, and that she was pleased with it, and wanted her bill.

The Commissioner: Did it come over her head ?-Witness : Yes.

Mr. Coleridge : Was it a nice aged bonnet? (A laugh.)-Witness: She You have put a difierent straw. I shall be obliged

The Commissioner : Did she want it disguised where the "junction" was? (Much laughter by the ladies in court.)-Witness: She paid for the bonnet there and then.

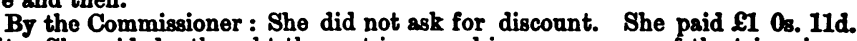
for it. She said she thought the cost incressed in consequence of the trimmings. She managed the whole business herself. - The witness then detailed severel instances of conversation to prove the rational manner in which Miss Ewings conducted herself. A lady was with her at the.time, but did not interfere.

Cross-examined by Mr. Smith : She did it in a lady-like manner.-(A laugh.)
Mr. Smith : Does it require anuch intellect to chose a bonnet?-Witnes :

Yes. (A laugh.)

Mr. Smith : Is it the first thing they learn and the last they forget?

The Commissioner : Take care, Mr. Smith-you are on ticklish ground!

The Witness-who appeared rather indignant at the observation of the

learned counsel-said, gentlemen are just as particular. (Renewed langhter.)

Mrs. Ann Carter, wife of Mr. George Carter, said : Miss Ewings, when passing her husband's shop, came in and had a conversation with her. She referred to her sister's buying a pair of spectacles in the shop ten years before. She mentioned her (witness) having had a little dog, and alknd what she had She mentioned her (witness) having had a little dog, and askd what she had adverted to the fact of witness's recollecting her. I did not observe the slightest trace of unsoundness in her mind. She conducted herself the same as any other person would. the shop.

mined by Mr. Karslake : The little dog used to sit at the door of

Mr. John Rickard deposed that Miss Ewings had a watch cleaned at his shop, for which she paid. The manner in which she paid him indicated that she must be person of sane mind.

James Portbury : I am a gardener to Dr. Shapter, at his cottage. I have seen Miss Ewings there several times. When there she particularly notioed Irmouth, the Belvidere at Powderham Castle, and the Belvidere at Bir Inwraice 
Palles. She talked most rationally about flowers, do. Her knowledge, in my opinion, denoted s person of superior mind.

Mary Wood, who formerly lived as servant with the Misses Ewings, deposed to the behaviour of Mtiss Phoobe Ewings. It was most rational and considerate. to the behaviour of She manifested great care in having her sister's grave properiy railed in. Sho employed a person to wateh the grave for some time in

work might not be injured before the railings were put up. videnco to prove the sanity of Miss Ewings. She said Miss Ewings was quick in in observation. Having had frequepinion that she was of unsound mind. The mould never have entertained escriptions which Miss Ewings gave her of her witness narrated in full the dination of the medical men. After a visit of Dr. state of mind aiter the exam fatigued and exhausted, adding "I have borne it Bucknill, she said she felt fatigued and neck in a very excited state, and sobbed. pretty well." Once she fell on witness's neck in a very excited state, and sobbed.; She said "I have gone through one of those questionings again; it is dreadful." Her spirits were low in consequence. Miss Anthong was then examined at great length upon some notes which she

nothing about mi Mr. Smith : I remember telling Mr. Gray that I had some notes. I made the notes partly for my own satisfaction and partly on cooont of Miss Ewings, when Dr. Tuke visited her, but not on account of Mr. Gray. She has counted out her money before me, but I never counted it with her. She volunteered to count the money with Dr. Tuke. Last night she said "All that I ask is to be put in the position of a christian woman. I am not mad, but they want to make me so." She constantly spoke of Mr. Elacombe as at the bottom of it, and sa between Mrs. Lowe and Mr. Fllacombe, which she could not fathom.

Dr. Geore Andrews Paterson: I practise at Tiverton, and have some Dr. George Andrews ; I have seen Mliss Ewings for the purpose of forming knowledge of lunary cases, an opinion upon the stato of her is collected and lady-like; she conversed Shapter's dinner table; hor man with those noar her, in many instancos propriety; she mentioned the namad of them in a manner which showed she understood what she talked about; she knew my object; after dinner I had a private conversation with her; she spoke of her tronble, of her being placed in an asylum, and also her fear of being placod of her trouble, of her being pla of these proceedings, and evidently a good deal in one again. but being aware of these proliar about her; I thought her manner affectod by them; there was wonderful for her time of she saw the print .of an epigald jog on the 20th of July, I saw her again at pleasant person so far as I could judgo: her lodpings. I her her; I said "Do you remember me?" She replied "Oh! yes, I remember meeting you at Dr. Paterson's ;" I did not correct her in this mistake of names ; meeting you at Dr. Pich had elapsed between the first and second interviews were the two months which had elaking of the bonnet bill, she said they had put favourable to her; in speakng of the bo said the Ewings were a much older Hewings or Flewings instead of that there was a knife grinder of that name. family than the Flewings, and that there was a recollocted things; there was (A laugh.) I think this went to show that she recole hes recovered from the nothing about her to indicate lunacy or insanity iffected.

paralygis, except in the tongue, which is slightly sfiected. Dr. Paterson was cross-examined at considerable length by Mr. Karslake, especially as to his opinion respecting the difference between exaggerated nop as a sions and delusions. Dr. Paterson said that in his opinion mania did not as
general rule follow paralysis. When such was the case, a change of character general rale follow

nerally took place. Mr. Lionel Roberts : 1 sm a surgeon in 16 to 18 years. I have had occasional exporion In of May I had an interview with Miss Ewings. I was she demeaned herself in but was not in conversation with her all that tim lady-like manner. I asked her the day of the week, and then the month. 
ratas

fore the converantion was natural. Wo had had convernation provilonty abiont

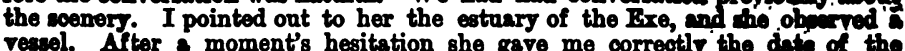
month. Her answers were unpremeditated. There was nothing to fidionto that she was different from others. I was induced, taking into condederation her great age, to consider that she had a strong mind.

By the Commisstoner : A right answer which she gave about th time sho had been in Ficter, together with her general demeanour, led me to blyipe that the was of strong mind.

Examination continued : The evidence I have heard does not alter nu belice that, considering her age, she has a strong mind.

Cross-examined by Mr. Karslake : For a lady of 80 she has a strong mimif. Mr. Karalake : When do you begin to discount from a lady's ame?

Witness : I think in this case you might have begun when she was 70.

Cross-examined by Mr. Karslake : I have never been asked before to discount a lady. (Laughter.) Some ladies would be far more imbecile at 70 than Miss Ewings is at 80 .

Cross-examination resumed : Hesitation in giving the day of the month showed carefulness. I have not had many lunatio patients. I did not know that she had been questioned about the days of the month.

By Mr. Coleridge : I consider her a sensible person; the minds of perrons at 80 are generally not so sharp as at 40 .

Mr. Charles Knighton Webb, consulting surgeon at St. Thomars Horpital, said : He had visited Miss Ewings, and found nothing which manifested uneoundnees of mind.

This being the whole of the evidenoe,

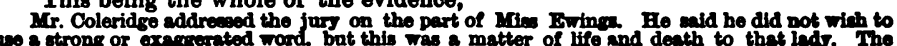

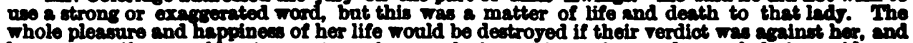

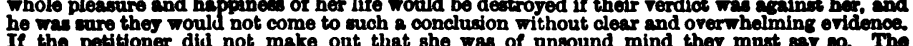
If the potitioner did not make out that she was of nasound mind they must sas 0. . The

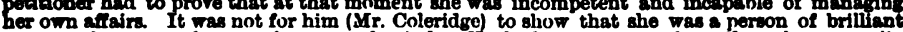
or even of strong and unusual powers of mind Ho had not even to show that ahe was quifts

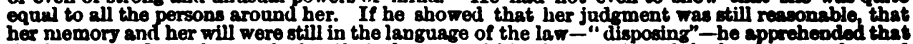

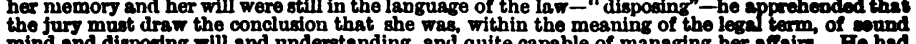
dispoosing will and understand doubt that the death of her sister produced a very prejudicial effect upon hor; but he dfa not know that beoause she was extremely wrapyed up in a beloved sister, and that the donth of that sester much afrectod her, therefore any foundation ras lajd at that timo of inanith of indirations of a mind of its balance. No doubt they knev instances where the doath of bolored relatives did prodince lasting offecte. Then she was not a moman fond uf buscineef was attompted to be shown that at this time there came upon her one of thome foolizh and inkang foelinga resulting in acts from which thes wero now to date the ineanity which was imputed to her. It had been suggested by his learned triend, Mr. Smith, that beoruse she had had her aister's rrave watchel, therefore sie was under the infuence of dolusion. The fect Fas that she the resils the loing mado to be

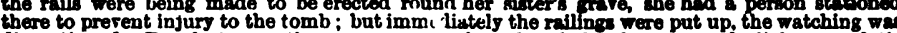
discontinued. But last year there came upon her the allitht-he repeatod slight-paraltito stroke: because from Mr. Sharp's and Dr. Kenrick's evidenoe, it wras clear that tho wa treated for paralysis in a milid form, and tlast after a time ahe was as well ase ever. Ho belleved

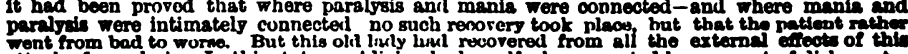

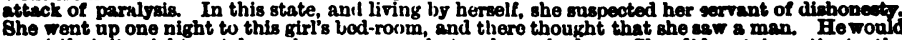
grant that it might not have been a man, hut only a sliailor. She dili not inveetigato the

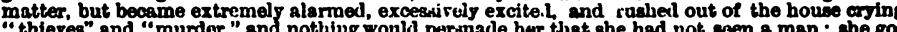
from besi to worse, was held down in her moom, anil having no authorised protoctor, no peno with whom she was on intimate terms, she was sent to a yeichbouring lunatic anylum. All thite while she was not mad, but in a highly exsited state of delirium. with impreesions mado upo hor mind poesibly real and possibly unreal. If, as he submittod, she really, whe not ineane, conk anything be more horrible. more distasterul to an old lady in her gtate? Bhe was labourin

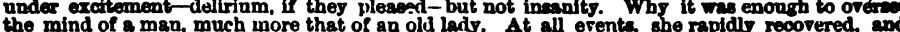

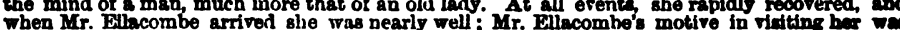
no doubt that of a man of the workl with $£ 12,000$ or $£ 13,000$ in view. The learned counel the reviewed the whole of the evidence in a very able manner. He contended that it did not prove ons unsoundess or mind; he terended Dr. Shapter from the atteak which had been medo upo him by the counsel for the petitioner. With respeot to the will it was only metarial to enquirs 
The Comminatonor: Ihractly

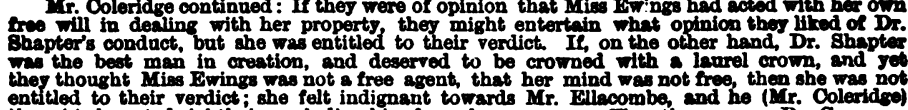
entitlod to their rerdict, she felt indignant towards Mr. Glacombe, and ho was not a bod rothis ; she had onl unkind remembrancess of him in respoct to the Chancers nor Mr. Fllacomber should be the objects of her bounty. These were the only persones Kept array at her expressed desire by Dr. Shapter. Miss. Ewings regretted that which whe might wall
have reason to regret-that she had not made her will, aud put tit out of the power of any peroon to interfere with her; she asted Dr. Shapter to make the will for her, and Dr. Shaptor took down her instructions with his own hand. Now were thoee instructions really her own? Wha How could he have got at the different percons' names? It was perfectly clear that he did-as he alleged-take down these names. It would have undoubtedly been much better if $\mathrm{Dr}$. Bhapter had then done that which he afterwards did-put the instructions in the hand of an attorney, and say, "Now you go and satisfy yoursell that that is really her will, and that I am

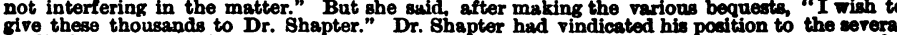
medical did afterwards, no doubt a great deal of this investigation would have been sared, but he dit

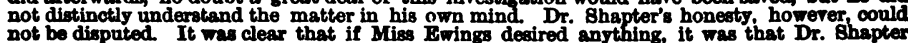
not be disputed. It was clear that if Miss Ewings desired anything. it was that Dr. Shapters
should hare her money. Despite all that had been said, there was not the shadow of an imputation upon the honour of Dr. Shapter. The medical evidence deserved notice, and he begzed the jury not to attach to that of Dr. Bucknill any more weight than to that of an ordmen witne 1 He denied that $\mathbf{D r}_{\text {. }}$ Bucknill had given it as a "judge or arbitrator." The imputetions about Mises Erings being " "Watched " Fere totally nufounded. In conclusion, he

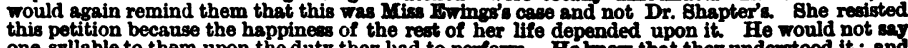
one gyllable to them upon the duty they had to perform. He mew that they understood it; : and the rest of the life of Miss Ewings were in their hauds. He trusted that they would not her to be interfered with for any mercenary or sordid motive. If they thought she conld no protoot hernelf and proporty they must gay so. but if that was left in doubt. and thes conaldered in the position she now occuplod.
It being now after eleren o'clock, the court adjourned.

\section{WEDNESDAY.-FIFTH DAY}

The court sat at ten o'clock.

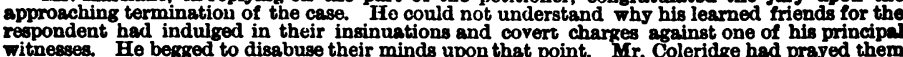
vitnesses He begged to disabuse their minds upon that point. Mr. Coleridge had prayed them this enquiry was to know whether she was in a state of mind to taks care of her own affairs Taeir verdict would not affect her future destiny, as regarded her residences or the mode in which choice. He, therefore, begged them to dismirs that thought from their mind. The only question was whether she was of sound mind and understanding caralable of taling. care of her own affairs The enquiry chiefly embraced the periol since the death of her gister in 1853 , had been a most murked ohange in the manner in which she was treated, and also in the way in which she conducted herself. Did they expect to find persons of sound mind ralling in the

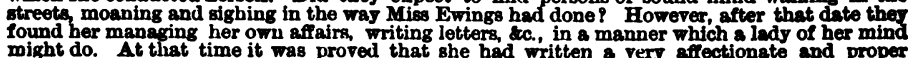
might do. At that time it was proved that she had written a very affectionate and proper attack? With the exception of signing two or three cheques and two wills there thas circumstance? In Docember, 1858, he said unhesitatingly that she had an attack of acute mania On the 30 th of that month had she or hail she not an attack of madneag mania or
delirium ? Bhe did beyond all doubt. There was the delusion as to the one-arm woman attempting to strangle her. and other things, when by the advice cf eight of her best friends it was to ask her about any man being $\mathbf{u}$ her room: Then, did Miss Ewings contract any delusion about the Roman catholics while in the Haydock Lunatic Asylum? Was there any delusion about the man being in her servant's roods and did that delusion not exiat nom? Was there not any dolusion about the Rev. Mr. Killacombe, who delirered her from the asylum ? It was suggested that great crue'ty had been used towards her at the railway
station, ind that upon seeing Mrs Bardsley ahe became violent, cried "MIfurier, police, and ther are going to make me a Roman Catholic" Instead of that, gentle persuasion was used. Shapter's oxtraordinary conduct, which he thought they muet eay with his counsel Mr.

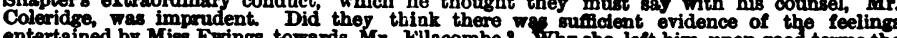
entertained by Miss Ewings towards Mr. Willacombe ? Why sho left him upon good termes the

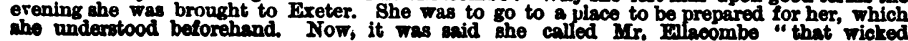


man, the atuse of all her trouble." Did Dr. Ghapter explain this owuee to her? Did he

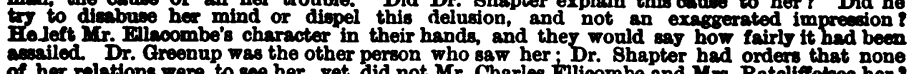

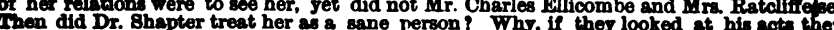
thoon that would be used towaris an insane person; she was treated just as a atild treated the moon From the constant visiting, her whole mind was flled with Dr. Bhapter, and Mr. inlacombe his pledge that no will should be made without his knowledis. How on earth could break his faith or justify that breach he could not understand. As a point of lam. Mr. promise given to 8 sont ought etrictiy to be performed. His learned friends having no facts to go upon, had villified overy one called before them, and had said "If it had not been for the will these proceedings would not have been taken." Dr. Greenup and Mr. FHlacombe were there to ask the Court of Ohancers to prevent designing people getting round her and having her money. As regarder

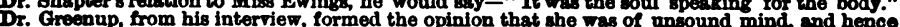
the petition. He (the leamed counsel) was sorry to have to endorse what Mr. Coleridge had mald, that Dr. Shapter had acted impudently. They must assume that Dr. Bhapter was incapable of a dishonest action. Could they then come to any other conclusion than that he Then her conduct to rards Mr. Beamont was remarkable. He did not think it was the proper offce of a professional man to say-" As people come hintivg after your money. motive in opposition to that of Mil. Coleridge, he should say that instructions were given for the Fill in consequence of the petition, and it was not the petitioner which brought them there, but Mras Hwings herself. Dr. Shapter, sitting by her side at the dinner-table, did not afford the as immetire that snch examination ghouh not be in the proconoe of another medicel man Then with respect to the will. Why dil not Dr. Shapter himself atteat the will? He would then have got rid of the $£ 14, C 00$ or $£ 15,000$ by a stmke of his pen. But no. It occurred to Dr. ghapter that if Miss Cousens signed the will-having a legacy-it would be invalid, and. therePore, the 19 guineas were to be given to her. He asked them to look at it as reasonable men of have so scted ise did not say it offengirely, but let them look at facts and drum their alusions about this matter. Dr. Shapter was asked "Wh:t do you intend to do with this mones thrust upon you?" He understoxd that he was to have sufficient power to pay the legacies, and yet to rejoct the other. Would the relatives have it? Yes, certainly. Then the men $\operatorname{sh} \theta$ dishliked were to have it. Was this not a deception? The thing she most disilked Was to be done the moment the breath is out of her bolly. Then they hail Mr. Gray's evidence truck then Then in the witnese-box, and when he left he (the leurned counsel) appealed to them the belief on everybody's mind was not that he was the sole residuary legatee ? And yet the fact was that if Dr. Shapter died Master Tom was to have it, and if he died the other children in equal portions. Was Dr. Shapter dealing fairly with the court? Was he dealing fairly with hin the chaction who had all their lifetime dealt with lunatics. Dr. Shapter was so blind, that he would not allow the scases to fall from his eyes and see that Mias Kwings laboured under delinions. The learned counsel then proceeded at great length, to review the whol, of the evidence of the rarious Witneses, whow testimony, he contended, established the fact that Miss Ewings was of unsound miln that the jury liked to speech which occupied three hours and \& hall. Mr. Karslake criticied the evidence of the Chorus in the Greek drama. (Laughter).

At the conclusion of the learned counsel's address the court adjourned until half-past two o'clock. Upon its resuming, the learned Commissioner, in accordance with an arrangement which he had previously made with the jury, appeared for a moment in court without his robes; and on withdrawing, was shortly afterwards followed by the jury to the Grand Jury-room, where Miss Ewings, accompanied by Dr. Shapter and Miss Consens, awaited their arrival. Wo understand that the learned Commissioner requested Dr. Shapter to withdraw, but permitted Miss Cousens to stay. He also allowed the two London agents of the solicitors for and against the petition, to remain and witness the proceedings. The interview lasted one hour, during which, as we are informed, the learned Commissioner and Miss Ewings were the only parties to a long and animated, and apparently easy and agreeable, conversation-two or three of the jury from time to time sending written questions to the learned Commissioner, which they wished put to Miss Ewings. She appeared at once to enter into the most friendly relations with the Commissioner, and did not seem to notice the absence of Dr. Shapter, nor the presence of so many strangers. Her manner, we learn, was easy and well-bred, and she was more ready to talk than the Commissioner, who sucoeeded, we are informed, in making her imbecility apparent to all present, and more and more distinctly till the interview was closed-he (the Commis- 
goner looking round significantly, and asking if the jury were satisfied; Miss Tinings observing, "I have more to say, but I fear I have fatigued you."

The Ioarned Commissioner said-Gentlemen of the jury, st length this pros to discharge my duties hitherto conscientionsly for the purpose of having laid before you evidence of a legitimate character, and excluding that which was illogitimate, in order that when that evidenoe of facts, of conduot, of motive, Tas before you, you might be in a condition to draw your own inferences. That is the function of a person presiding over an enquiry of this description, and I have endeavoured to discharge it honestly, as I am sure you have the still more important duty devolving on you. I am greatly gratified at being assisted in this enquiry by the presence of 23 gontlemen colleoted from different parts of this great county-gentlemen of ednoation of position, of experience of life, knowledge of character, and acquaintance with posiness, and who under my personal observation during these five deys through which this trial has necessarily, in my opinion, lasted, have listened with signal patience and attention to the evidence. The publio is greatly indebted to you. Tho case has passed now into a new phase. You see no loarned counsel at that table ; they are called away by professional duties oleowhere; but I beg, as a gentleman who never was on this circuit before, to express publicly, what I dare say you agree in, my real admiration of the tomper, the courtesy, the discretion, the eloquence, and the ability with which counsel have assisted us in our enquiry. I am very glad to see on the jury conentletann with whom I was acquainted in former years and who is of my own walk in the profession and experienced in the conduct of legal proceedings. The question now is one to be determined by you and me. When I say "and rae," I mean only as the presiding officer of the court in which you are assembled, and of which you form part. But the verdict which you are to pronounce, is no verdict of mine-I am no party to it-I have nothing whatever to do in sharing your responsibility, or exercising your rights. All that I can do is to suggest to you some observations of a general character to enable you to distinguish between the present and the former phase of this enquiry, in this respect. Whereas throughout we have had eloquent this enquiry, in this respect. Whereas throughout we have had eloquent alients most advantageously before you, keeping back, as far as they could fairly and honourably, all those parts of their respective cases which they wished to conoeal from you, and to bring forward into prominence those parts which they wished to present to you in a favourable aspect. That has passed; and now he who addresses you, has nothing to do, but, having the same object as yourself, to give you a few suggestions, from the experience I am presunied to have, which may contribute towards enabling you to discharge your duties satisfactorily to yourselves and the country. Since we met an hour ago in this satisfactorily to yourselves and the country. Since we met an hour ago in this court the matter has passed into still another phase, of which the public knows nothing up to this moment. You and I have been for the last hour closetod
with the lady whose melancholy case is before us. I ask you what impression that interview - which I conducted on your behalf-has produoed upon your minds? Has it dislocated the evidence which has been laid before you during the last five days? Or has it signally consolidatod and confirmed it? Does it lead you to believe that false facts have been told you, or erroneous inferences drawn from true facts? You have had evidence from those who have been surrounding this unfortunate lady during the last six months, some of them desirous apparently of presenting her before you as a lady in the full possession of her faculties. They say "We never saw a person of greater strength of intellect; quite capable and fit to discharge all the ordinary duties of life, with uncommon acuteness to deal in little business matters; to mingle with society, and in all other respects exhibiting herself as a rational, accountable, responsible, and intelligent being, able to vindicate her own rights, to protect hereelf and her property, and to prevent the one or the other from becoming tho viction the vichim of over-reaching of any kind. I ask, after the interviow which you have just had-and into which 1 shall not publicly enter hore,- the verdiot boing yours and not mine-nobody elses but yours-upon your solemn oathswhat is the verdict to be? Do you believe at this moment-after what you have soen and heard-that this lady now is, or is not of sound mind, and 
formed an opinion of my own, but I shall not trouble you with it. I shall not presume to disturb the exercise of your duties or your functions; but I hall if you think fit bring before you in detail all the evidence that you have heard. If you think it unnecessary, you can prevent my doing it, but if you think it consistent with your sense of duty-and the public behests of justicethat I should go through the caso in detail, here am I prepared to do it, and, indeed, most anxious to do it if you require it.

The Foreman : Shall I enquire of my brother jurymen ?

The Commissioner: I wish to go through it if you think it necessary, but don't lightly give an answer one way or the other.

The Foreman: Shall we retire for a minute or two?

The Commissioner: By all means.

Several jurymen intimated that they did not require to retire, and aftor a brief consultation the

The Foreman said : We need not trouble you to read the evidenoe.

The Commissioner : Are you prepared to pronounce jour verdiot upon the question I have given you, or do you wish to retire?

The Foreman : We wish to retire.

The Commissioner: Perhaps, before you go, you will allow me to say a for words to you. You are charged with a question of very great importance, of doep interest to the individual concerned, and to the public; I shall make after your intimation only a few general observations. Do not leap rashly to a conclusion. If your minds are really made up after what you and $I$ have soen conclusion. If your minds are really made up after what you and I have soen during the last hour, combined with the evidence before you, then it becomes your duty, upon your solemn oaths to say-is Miss Phoobe Ewings, or is she not,
at this moment, in your judgment-as men of the world-gentlemen of experience of human affairs, and knowledge of character- of a sound mind, so as to be capable of governing and protecting herself and property? That is the question. Before you retire I beg to say that having already complimentarily (a) alluded to the oxertion, from Mr. Coleridge for the opponents of the petition-and this morning that of Mr. Karslake for the petitioner. I beg to say that I think their addresses, founded as they both are on the entire evidence on both sides, after the whole has been laid before you, are far more entitled to your attention than the addresses which were delivered before that was the case. I really think thero has not been a mis-statement of a single fact by Mr. Coleridge last night, or by Mr. Karslake to-day - or I should have interposed at once and corrected it-for you cannot but have observed what extensive notes I have taken. I have watched with particular vigilance every word, and each has abstained from any watched with particular vigilance every word, and each has abstained from any mis-statement. Assuming, therefore, that each has presented to you the facts exactly-more than that - that everything that could be urged on both sides made of each case - then you stand in the favourable position of being able to apply to it your last hour's experience, and say to which side of the line, dividing sanity from insanity, you incline in the solemn verdict you have to prononnco and I inust disabits, you inaling in an insult to gentlemen of your knowledge of life and of the law to do so-as to what the result of your verdict will be. If you say this lady is of unsound mind, don't suppose that you will consign her ignominously and cruelly to a dungeon; nothing of the sort. Let me tell you the course which will be taken by the law, and which I now authoritatively explain to you. This step is a step of mercy and of protection. If you think the lady to be at this moment incompetent to resist the attempts of those who would deceive and overreach her for their own purposes, surely it is an act of mercy to place her out of the reach of such persons. If, on the contrary, you believe she is in no such danger-but has all her faculties fairly about her-having regard to her advanced years-and that she can really take care of herself as a lady 80 years of age-and you recolleot what she said to me-then if you think she is able to take care of herself and her property, it will be an act of mercy and of justice, as, in the other case, to say that she is competent. Suppose you say she is not competent, what will take place? The lady will be under my charge-a most anxious, a most responsible, and viligant charge. And as to her being incarcerated in a Lanatio Aoylum, leave that to the Lord Chancellor, the Lords Justices, and the humble individail 
who is now addreesing you. Gentlemen, I would not hurt a hair of her head, nor would one of you. I would not bring down her grey hairs with sorrow to the grave, or humble her, by incarcerating a lady (who has spent, as she herself feolingly remarked, a life of fifty years in unimpeachablo respectability, in a mad-house. God forbid. The evidence on both sides which has been given by highly qualified men-and persons of honour who are not medical men -is, that she ought not to be confined in an asylum. If you think she ought to be pronounoed of unsound mind, and that she ought to be protected, all personal pronounced of unsound mind, and thast sheiously be secured to her, and secured comforts of every description will most anxionsly be secured to her, and seoured
by the intervention of those who have the deepest interest in her wolfare, and by the intervention of those who have the deepest interest in her welfare, and
who will have to give a very good guarantee before being allowed to assume the who will have to give a very good guarantee before being allowed to assume the trust is under constant surveillance, so that if they go wrong there are those in oxistence whose interest it is to point out that they are going wrong. The lady herself suffers no indignity whatever. She has full liberty, consistent with her mere personal safety; and as to her property it is henceforth in the custody of the law. But the first object of the law, as I tell you-responsibly administering that law-is to let her have every imaginable personal comfort, and even luxury, that her income and her means will allow. Gentlemen, before you withdraw I will make one observation on a painful and delicate topic, conneoted cesentially and inevitably with this enquiry. I am not come here to try the ralidity of this lady's supposed will. It may be waste paper for aught I know, or it may be an operative document. But the reason why I have alluded to itas responsible for the conduct of this enquiry and anxious not to exclude, but to let in light apon it from all quarters-is this-that the transaction respecting that alleged will is one of a most remarkable character-undoubtedly to some that alleged will is one of a most remarkable character-andoubtedly to some syllable of a personal nature Coming here in the administration of lunacy law, $I$ do not desire to leave behind me a single rankling wound or utter an expression which may be offensive or prejudicial to the interests of any one whatever. I, therefore, make no remarks on the motives which have been alleged rather freely, on one side and on the other, against persons interested in this will. I do not say whether in my judginent that will is worth the paper on which it is written, or whether it is an operative instrument. I do not say whether it was extracted from this lady by Dr. Shapter when she was completely under his was extracted from this lady by Dr. Shapter when she was completely under his control, and when he was-as was somewhat sarcastically and humorously said
by Mr. Karslake-in the relation of soul to the body of Miss Ewings. I by Mr. Karslake-in the relation of soul to the body of Miss Ewings. I be that Dr. Shapter was acting from the purest motives, and yet has ooted hastily, precipitately, and indiscreetly. I offer no opinion. I invite you to avoid the pain of pronouncing any opinion; you are not called upon to do so. $\mathrm{ft}_{t}$ is simply one element in the enquiry into the state of her mental faculties. There may be among you, gentlemen the state of her mental faculties. There may be among you, gentlemen acquainted with business in all its branches. It is for you to saj whether having heard the evidence as to that alleged will, and the manner in which it was obtained, and having seen and heard that lady for yourselves,
whether that alleged will could have been obtained consistently with with the complete sanity of the lady. But I am anxious to make myself understood. It is only one element-one view of the subject. I repeat that I express no opinion one way or the other. If you should pronounce this lady of unsound mind, it will not affect the validity of that instrument, which if ever it be attempted to be enforced must be subjected to the keen scrutiny of it be attempted to be enforced must be subjected to the keen scrutiny of
competent tribunal. If you pronounce her to be of sound mind, neither will competent tribunal. If you pronounce her to be of sound mind, neither will
that affeet the validity of that supposed will; for in that case also will it bo submitted to a competent tribunal. Therefore, I beg to dismiss you to your responsible duties in your private chamber, bearing in mind that the matter of the will is only one element to enable you to look into this lady's mind, and ray whether you think it is, or is not, sound. You have to say whether in your jud of herself and her property. That is the commission entrusted to me under the great seal.

One of the Jury: Would you kindly give us the rery words of the order and commission?

The Commissioner : The question I put to you is as to her existing condition at the present moment. 
The oreman : That is the simple question?

The Commiasioner : Nothing else. The evidence as to the paet is onls to bring you to a conalusion as to what you think her present stato is.

The jury then retired, and returned in about ten minutes, when the Under Sheriff oalled over their names. Having all answered,

The Commiagioner and : Mr. Foreman, on the part of yourself and fellowe, do jou say that Phoobe Ewings is now, or that she is not, a person of sound mind, so as to be sufficient for the government of herself and property?

The Foreman: The jury say that Phabe Evoings us not now a person of conund mind, $\infty$ as to be enfficient for the government of heredf and property. I am requeded to inform you that this is an unanimous verdict.

Upon the delivery of the verdict there was some slight applause in court which was instantly ohocked by the Commissioner.

The Commissioner then informed the jury that they would have to affix thair signatures to the return of their finding. Before doing so, he hoped they would do him the justice to say that he had endeavoured scrupulously not to obtrude his own judgment upon them: but, as they had now pronounoed their verdict, he might state that he entirely concurred in it. They might safely trust Miss Ewings in his hands, and she should never know the difference between her present and her future mode of life, as far as related to her personal ease, comfort, and enjoyment.

The Foreman of the Jury: I am desired by the jury to express our atrong sense of the kindness and courtesy with which we have been treated bJ jou.

The Commissioner: Gentlemen, I am very happy to receive this tribute of your approbation. It has been a very agreeable duty to me to preside over 80 large and able a body of gentlemen of the county of Devon. - The enquiry in now alosed.

\section{THE INTERVIEW WITH MISS EWINGS.}

Wo are indebted for the following to the kindness of a gentleman who was precent, and who took full notes, the correctness of which we have had an opportunity of acoertaining from another quarter :-

IOTIE OF THE INTREVIEW BETWBEN MISS RWINGS, THE COMOCSSIONER, $\triangle$ NDD THE JOBY.

17th AUGOST, 1859.

The Commissioner (we are informed) introduced himself to Miss Evinge (who was elegantly dressed) in the Grand Jury Room at Exeter Castle, and conversed with her eheerfully for a few minutes, standing near the window, on the Teather and other indifferent subjects. Mise Cousens was also present, sitting cloes to Miss Erings, but never speaking to her. The jury and the two London coee to afents of the respective solicitors on each side entered within a few minntes' Commissioner and Miss Ewings also took their seats at the table. Miss Ewing rat between the Commissioner and the Foreman of the Jury, who took copious notes.

The Commissioner spoke to Miss Ewings about Warrington.

Miss Ewings said she had resided there until recently.

The relatives there, and in Cheshire, mentioning one of them. Ho also alluded to the Epigram on the marriage of Mr. Greenall, the member for Warrington.

Miss Ewings was much amused, and said she could not remember who wrote it.

The Commissioner said he had heard she was 80 years of age, but he really

could hardly believe it from her appearance, that she looked more like 60 .

Miss Ewings smiled, and said she should be 80 on the 18th of August-" tomorrow."

The Commissioner made allusion to her dark hair.

Miss Ewings: It is not my own hair. After some other carral remarke,

The Commisaioner asked if she had not " had trouble."

Mise Bwings : Yes, I have had wy troubles.

The Commissionar alluded to har siater's death. 
Mis Intings wid it had dietreeed her very muoh, repenting "I have had mo troubles.

The Comminioner aled what other troubles she had had? Mies Bwinge : I was afraid they would do for me. I was cent to an asylum. The Commissioner questioned her about this, expreasing great interest, and aid it was important ho should know all about it.

She began eaporly - I was aitting at home about Christmas. I think it must have been two days after Ohristmas day, and they told me I could not stay in my house, that I should bo in danger of my life. They said I must Igo to stay two or three days with a friend.

The Commissioner asked earnestly what the danger was?

Tim Ewings: There were bad people about. I could not get out of my own house. A noise was made. I tried to get out, and they bolted the door. As soon as I got throwgh one door they bolted it, and I went through another. The women came and held me by my hands and feet, and thrust me feet foremost in at the door; then my neighbours entered the house, and I was gafe. It was not night time. I was afraid to go to bed, and sat up all that night. The women said " how strong she is !"- "Neighbours and that" got me bome.

The Commisaioner aked, who told her it was not safe to be in her house?

Mis Ewings : Oh ! a great many said I must go ; that I should not be safe another day in the house; they told me it would fall down; they asked me to 80 to a friend's for two or three days, near Mr. Greenalls; they did not go the right way; they went another way; the horses never intended to go the right way ; they went towurds Winwick; when I found them going the wrong way I told them; they said it was right.

The Commissioner : Who said it was right?

Miss Ewings : The post-boy said it was right; I tried to get ont of the carriage.

The Commissioner asked who were with her.

Mis Ewings: Oh! rough women; they got their clothes (or closed) round me; they kept me back; when I got to the asylum I said "Good God ! what is to become of me?" another woman pretended to be very genteel and said "Oh ! I'l take care of you ;" I did not know where I was going; I thought it was some bad place; it was a handsome place, large, with a handsome stair-case ; after waiting some time some person came; it was a large place with a grand stairease; we entered into a handsome drawing-room; after a little time they came and got the carriage stopped; they sent my clothes; a person came who always attended these people, Elizabeth; she came to protect me; she asked if I would have my tes ; I took tes; she asked if I would go to bed alone? I said I should prefer having another to sleep with me; the door had a great bolt; they bolted me in, "we were fastened in ;" they had a brass bolt .to shut me in, and they left mo by myself; Elizabeth slept with me; I lay late, I was so exhausted; a lady came in the morning, one of the heads; eight o'clock they said was the time for me to be np; I thought I might be there for my life.

The Commissioner asked what the place was ? Mias Ewings : It. was an asylum; I found out afterwards it was Haydock
Lodge; I have since heard of Haddock Lodge, that it was the same place (repeating the words several times). Here she was several times asked by the Commissioner what the asylum was, without his receiving any answer.

The Commissioner asked whether it was a uunnery, and whether there was

a Iady Abbess, and whether there were any Roman Catholics there?

Miss Ewings : I don't know whether there were Catholics. I mind my own business, and am a Christian-one of the true faith!" I found it was Haydock

Iodge.

The Commissioner asked whether she would become a Roman Catholio? Miss Ewings (very earnestly) No; I would die before I would become a Catholic.

The Commissioner asked whether they had tried to make her a Roman Citholio ?

Miss Ewings : I don't know that they ever tried to make me a Catholio

at all. I said I am of the true Protestant Church-true Church of Christ.

The Commissioner questioned her about going to a Roman Catholic Chapel.

Kiss Ewings : Sarah (meaning probably Hlixabeth) said, would you like to

go ? there is no difierence. They asked me to go. They read the prajers of 
the Churah-but some were left out. They had no surplice on. Here she spoke of seeing the drove of dismal people and other attendants telling her they were the lunstics (paupers), and her horror at finding she was in a Lunatic Asylum. (The conversation was very rapid at this part.)

The Commissioner asked whether she went to the Roman Catholic Church ? Miss Ewings : I did not go that way.

The Commissioner said he had heard that she had very generously given 8500 to the Society for the Propagation of the Gospel ? Miss Ewings : I onght to have given more than the $\$ 500$.

The Commissioner asked about her sister ?

Miss Fwings : I lost my sister.

The Commissioner asked if she (Miss Ewings) was not a native of Devon ? Miss Ewings : Yes.

The Commissioner questioned her about her sister's vault having boen watohed ?

Miss Ewings : After my mother's death, and my sister's death, I did not like to leave her remains.

The Commissioner asked why she had her sister's vault watched ?

Miss Ewings : I had her grave watched. I thought the grave was not very rood, and that the boys might knock down the bricks.

The Commissioner questioned her as to the purchase of some spectacles,

and whether she had not given two guineas for them?

Miss Ewings : I gave $£ 2$ for them, not two guineas.

The Commissioner asked if she had not some friends in Devonshire named Ellacombe?

Miss Ewings : Ellacombe? Yes, I know a clergyman's lady and her son,

Mr. Charles Ellacombe.

The Commissioner asked if she had not some relation of that name ?

Miss Ewings : I know another Ellacombe; I dare say you do too.

The Commissioner asked if he took her from the Asylum, and about the circumstances ?

Miss Ewings: When I got to where I was kept at the Asylum, I was thankful to get out any way. I never heard of him before, but he said I was at liberty to leave with him. This Ellacombe and Mr. Nicholson came; I never heard of him before. It was to get my money. He got me ont to put me worse in. I stopped at Mrs. Iowe's two or three days as a friend, and the next day, in. I stopped at Mrs. INWe's two or three days as a friend, and the next day, Sunday morning, I said to Mrs. Lowe the first thing I have to do is to thank
God for delivering me from the Asylum. Fllacombe came and wished to shake God for delivering me from the Asylum. Fllacombe came and wished to shake
hands, and at the church the clergyman and this Fllacombe administered the amarament.

The Commissioner asked whether she would give more money for the Church ?

Miss Exings: I don't know that I can afford to give any more to the Chnrch. Abont the Asylum I should like to finish it, if I am not fatiguing you. When I got out the next day Sunday, Ellacombe said, "Well, Miss Ewings, I When I got out the next day Sunday, Ellacombe said, "Wel, Miss Ewings, I have no intention of going; I would rather go to the poor-house.

The Commissioner questioned her about Mrs. Lowe acoompanying her to the rilway.

Miss Evings : Three days after, Mrs. Iowe was a cruel enemy ! She tried to send me away bag and baggage. She forced me away in one of those common cort of oarriages. Dr. Shapter came to see me in the morning.

The Commissioner asked abont Mr. Fllacombe visiting her at Miss Consens' ? Miss Ewings : I won't say but what Fllacombe was there. I don't think he

was. I never heard of his being there. Dr. Shapter got rid of Ellacombe. After some other conversation about the window blinds and other littlo matters,

The Commissioner asked her if she could get her money when she wanted any?

Miss Ewings : If I wanted any moner Dr. Shapter would provide it, to be sure. He is my protector. He always lets me have money.

Miss Ewings, (without being asked) took out her parse and counted ten covereigns and o-half sovereign, twice, into the Commiseioner's hands, with pleased sir. 
LVIII

The Commissianer asked her if that did not make ten guineas?

Miss Ewings said : Oh ! no, not ten guineas, $£ 1010$ s.; it has nothing to do with ten guineas-there are no guineas nnw.

She offered the Commissioner two sovereigns rather bashfully, and anid $I$

will give you a couple of guineas if you will not be offended.

The Commissioner asked what they were for?

Miss Ewings : I will give you a couple of guineas, adding (after a pance and apparently embarrassed) for the poor.

The Commissioner returned suddenly to the subject of her leaving Warrington.

Miss Ewings : I did notknow where I was going when I left Warrington.

The Commissioner asked whether she had made her will?

Miss Ewings (quickly): I have made my will.

The Commissioner asked how she had given her money ?

Miss Ewings : I have given all my property to Dr. Shapter. I have no kind

friends; he is very kind-he is my protector-it is my own act and deed

(emphstically.) I thought it a very blessed thing to have a kind friend.

The Commissioner asked the amount of her property?

Miss Ewings : $£ 13,700$ is the amount of property.

The Conumissioner asked what her income was-whether $£ 100$ a-year?

Miss Ewings : $\$ 100$ a-year! " Lor !” what a way you talk ! (laughing.)

The Commissioner asked if she had money when she required it?

Miss Ewings : When I want money I can always have it. (Showing hor

purse, which, we are told, contained a fow shillings short of E12.)

The Commissioner questioned her abont Dr. Shapter.

Miss Ewings : He is my friend and protector, and also my guandian.

The Commissioner asked if she had made any one besides Dr. Shapter "residary" legatee.

Miss Ewings : I don't think there could be two residary legatees.

The Commissioner: Will you not make me your residary legatee? I am your friend also.

Miss Ewings (laughing) : Oh, yes-perhaps so! I will make you residuary legateo too, (or with Dr. Shapter.)

When the subject of the spectacles was mentioned, the Commissioner said he also wore glasses, but they were not gold like hers-only steel. She said she had had dark spectacles too. The Commissioner asked her to try to see with his. She put then on, but said they did not help her. She then put on her own glasses, and the Commissioner took out his small Pocket-book Almanack (Goldsmith's,) shewed her the title page, and asked if she could read it through her glases? After a slight mistake, reading "Smith" for " Goldsmith" which she herself immediately corrected, she read it right-"Goldsmith," and also one or two other words.

The Commissioner said more than once, "I am afraid I am fatiguing you." But Miss Ewings said "Oh, no! I want to tell you more, but I am afraid I am fatiguing you. I should like to tell you all about it-about my troubles.

She several times expressed great horror of being put into an asylum again; and when the Commissioner assured her he would take care that she never saw the inside of one again as long as she lived, she expressed great gratitude. She several times grasped the Commissioner's hand and held it in hers. She often smiled, sometimes laughed outright, and once was nearly in tears when she alluded to her sister's death. She said she knew Winnick Church; it was a ndeed.

Throughout the interview Miss Ewings conversed in the most affable and cheerful manner with the Commissioner without embarrassment, or apparent fatigue, and seemed not to be aware of the presence of the jury.

Miss Cousens sat close to, but a little behind her, and was never once turned round to, or appealed to, by Miss Ewings; who also, we are told, took no notice of Dr. Shapter's withdrawing.

Two or three questions were proposed by jurymen, through written slips passed to the Commissioner.

When the Commissioner took his leare, shaking Miss Ewings cordially by the hand, she expressed a hope that sha had not fatigued him, and said she should always be happy to see him, and tell him more. 
THE JOURNAL OF MENTAL SCIENCE 
EXETER:

PRITTED BT WILLIAM POLLARD,

MORTH BTREET. 


\section{INDEX TO VOLUME V}

Annual Moeting of Association of Medical Officers of ${ }^{\text {PAgs. }}$ Asylums and Hospitals for the Insane - $\quad 56$ $\begin{array}{lllll}\text { Appointments } & \cdot & * & 156,300,588\end{array}$ Association of Medical Officers of Asylums and Hospitals for the Insane, Special Meeting of - . 373 Atkinson, James, Prison Letters of $\quad$. 430 Baths in the Treatment of Insanity, by H. Tuke, M.D. - 102 Bran Bread, Efficacy of, in Melancholia . . 408 Browne, Dr., last Report on Crichton Asylum • 200 Boyd, Robert, M.D., On the Necessity of Insanity as a Branch of Medical Education • • $\quad 573$ Bucknill, John Charles, M.D, on Hamlet • • 1

\begin{tabular}{|c|c|c|c|}
\hline " & " & on Reports of English Asylums & 157 \\
\hline 9 & " & on Reports of Scotch Asylums & 200 \\
\hline$"$ & " & on Reports of Irish Asylums & 218 \\
\hline$n$ & $"$ & on Reports of East Indian Asylums & \\
\hline " & " & $\begin{array}{l}\text { on Report of Commissioners of In- } \\
\text { quiry on the state of Lunatic } \\
\text { Asylums in Ireland, \&c., \&c. }\end{array}$ & \\
\hline
\end{tabular}

" $"$ on Observations on the Report of the Commissioners of Inquiry into Lunatic Asylums in Ireland, by J. Nugent, M.D., Inspector of Lunatic Asylums • ib

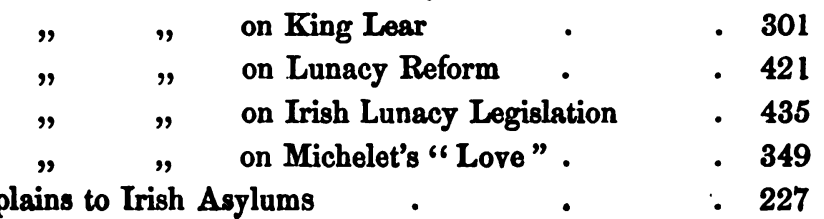


vi.

Index.

Commentaries on Insanity, by D. F. Tyerman, Bsq 366 ,

Commissioners in Lunacy, Twelfth Report of 245

" Supplement to Twelfth Report of 547

Commissioners in Lunacy, Scotland, First Report of 445

Conolly, John, M.D., on Residences for the Insane • 411

Conolly, Edward T., Esq., on Suggestions for Amendments of the Law Relating to Private Lunatic Asylums • 297

Corrigan, Dr., on Visiting Physicians • • • 435

Davey, Dr., on the Relations between Crime and Insanity 82

Discussion upon Dr. Tuke's Paper, on the Diagnosis of General Paralysis

- $\quad 78$

Expectancy of Life in the Insane $\quad \cdot \quad 280$

Excerpta from the Evidence given before the Select Committee of the House of Commons on Iunatics - 482

General Paralysis, Essay on, by Dr. Harrington Tuke 78, 575

Ganglionic Nerrous System, by Dr. Davey . 155

Hamlet, a Psychological Study . 1 . 1

Huxley, Dr., on the Existing Relation between the Lunacy

Commission, and Medical Superintendents of Public Asylums .

- 95

Jacobi, Dr., Obituary Notice of $\quad • \quad$ • $\quad$ • 289

Instructions of Scotch Commissioners on Building Asylums 478

Inquisition of Lunacy on Mrs. Turner $\quad$ • $\quad 114$

" " on Mr. Ruck • . 122

Irish Asylums, Reports of $\quad \cdot \quad$ • $\quad$ - 215

" Proposed Legislation, on . 435

Irregularity of the Pupils from Central Causes, by Dr.

Palmer . 20.046

Laws relating to Private Lunatic Asylums, Suggestions

for Amendment of . $\quad$ • $\quad$ • $\quad 297$

Lear, A Psychological Study $\quad$ • $\quad$ • $\quad 301$

L'Amour, par J. Michelet ․ $\quad$. 349

Legislation on Irish Lunatic Asylums $\quad$ • 435

Lunacy Law Reform . $\quad$ • $\quad$ • $\quad$ • 421

Morningside Asylum, Visit of Association to 101

Notes on Prognosis in Mental Disease, by C. L.

$\begin{array}{llllll}\text { Robertson, M.B. } & \text { • } & \text { • } & \text { • } & & \end{array}$ 
Index.

vii.

Necessity of Insanity as a Branch of Medical Education,

by Robert Boyd, M.D. $\quad$. $\quad$. $\quad$. 573

Object and Distribution of Asylum Reports . $\quad$. 159

Observations on the Report of the Commissioners of Inquiry into Lunatic Asylums in Ireland, by J. Nugent,

M.D.

222

Officers of Association, Election of $\quad$. $\quad 69$

Official Report of the Special General Meeting of the Association of Medical Officers of Asylums and Hospitals for the Insane . $\quad$ • $\quad$. $\quad$. 373

Opium Eating of Lincolnshire Peasantry $\quad$ • $\quad$ - 173

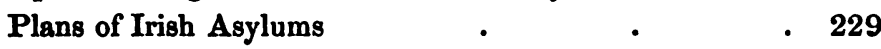

Poorhouses, Lunatics in the Scotch $\quad$. . 465

President's Address . $\quad$ • $\quad$ • $\quad$. 71

Private Lunatic Asylums, Newspaper Attack on $\quad$. 146

Prognosis in Mental Disease, Notes on • $\quad$. 257

Proposed Legislation on Irish Lunatic Asylums, The . 437

Reflex Muscular Action in General Paralysis, Note by Dr. Bucknill

Report of Committee of Association on the Lunacy Bills 440

Reports of Lunatic Asylums ․ . $\quad$. 157

Report of the Commissioners of Inquiry on the state of Lunatic Asylums, \&c., in Ireland • $\quad$ - 222

Report of the Commissioners in Lunacy to the Lord Chancellor

Report of the General Board of Commissioners in Lunacy for Scotland $\quad$. $\quad . \quad$. $\quad$. 445

Residences for the Insane, by Dr. Conolly . . . 411

Robertson, C. L., M.D., on Notes on Prognosis in Mental Disease . 257

",$\quad$ on Report of Commissioners in Lunacy for Scotland . 445

Sea-side Residences for the Insane. $\quad$. 154

Shaftesbury, Earl of, Evidence of, before Select Committee on Lunatic Asylums $\quad$ • $\quad$ • $\quad$. 482

Skae, Dr., on General Paralysis . . .

Statistics of Asylum Reports . . $\quad$. 220 
viii.

Index.

Statistics of Scotch Asylums

Suggestions for Amendments of the Laws relating to Private Lunatic Asylums, by Edward T. Conolly, Esq. 297

Supplement to the Twelfth Report of the Commissioners $\begin{array}{lllll}\text { in Lunacy } & \text { • } & \text { • } & \text { • } & \text { - } 547\end{array}$

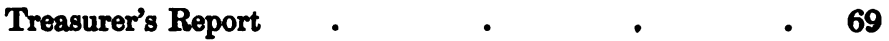

Tuke, Harrington, M.D., on Warm and Cold Baths in the Treatment of Insanity . 102
on General Paralysis
78,375

Twelfth Report of the Commissioners in Lunacy

- 245

Tyerman, D. F., Esq., Commentaries on Insanity

366, 585

Visiting Physicians to Asylums

. 241

Workhouses, Detention of Lunatic Paupers in

. 175 


\section{Association of Medical Officers of Asylums and Hospitals}

for the Insane.

$A^{T}$ the ANNUAL MEETING held at Liverpool, on the A 26th July, the following Office-bearers were elected for the year 1859-60.

President-Sir Charles Hastixgs, d.c.l., Worcester.

President Elect-Dr. Bucknit,, M.S., Co. Asy., Devon. Ex-President-Dr. Conolly, D.c.L., Hanwell.

Treasurer-WM. Lkx, Esq., M.S., Co. Asy., Oxford.

Auditors-Dr. Harrineton Tuke, Manor Honse, Chiswick; Dr. Sherlock, Co. Asy., Worcester.

Hon. Secretary (General)-Dr. Lockнart Robzrson, M.S., Co. Asy. Sussex (Hayward's Heath).

Hon. Secretary for Ireland-Dr. Srewari, M.S., Dist. Asy., Belfast.

Hon. Secretary for Scotland-Dr. Wrvert, M.S., Roy. Asy., Dundee. Editor of Journal-Dr. Bucksuc, M.S., Co. Asy., Devon.

This Committee of Management was augmented by the addition, under Rule XII, of the following six members of the Association :

DR. Hoon, Resident Physician, Royal Bethlem Hospital.

Dr. Camprell, M.S., Co. Asy., Brentwood.

Dr. Skaz, M.S., Royal Edinburgh Asy.

Dr. Pa cr, Camberwell Ho., London,

Dr. Daver, Northwoods, Bristol.

Dr. LA zor, M.S., Richmond District Asy., Dublin.

The following new members were elected :

G. Birkert, Esa., Northumberland House, Stoke Newington.

Dr. Brownz, Hayes, Middlesex.

Dr. LANgdon Down, Idiot Asy., Reigate.

D. Rossiter, Ese, Haydock Lodge, Ashton, near Warrington.

Dr. Lormer, Roy. Asy., Perth.

Dr. Lindsay, Co. Asy., Wells, Somerset.

J. S. Biggs, Esa., Co. Asy., Surrey.

F. Negdras, Esq., Lunatic Hos., York.

DR. Duncan, Colchester.

M. L. Rogrns, Esa., M.S., Co. Asy., Rainhill

Dr. Me Krnstre, Armagh, Distr. Hospital.

Dr. Wood, Barwood House Asy., near Gloucester.

Dr. Dixon, Hoxton House Asy., Loudon.

The Annual Subseriptions for 1859-60, (due in advance,) are now payable to the Treasurer, WM. Lex, Esa., County Asylum, Oxford.

It is particularly desired by the President and Committee that all arrears be forthwith disckarged.

Hayward's Heath, Sussex, September, 1859.

\section{LOCKHART ROBEITSON,} Hon. Sec.

\section{Just Published.}

Dedicated, by Permission, to the EarL of Shamessurx.

\section{On the State of Lunacy and of the}

Legal Provision for the Insane; with Observations on the Construction and Organization of Asylums. By J. T. AnLmge, M.B. A.B., LosD., L.R.C.P., LosD., formerly Superintendent of St. Lake's Hospital. Londou: John Churchill, New Burlington Street.

WILLIAM POLLARD, PRINTER, KORTÍ BTREET, EXETER. 